Analysis Report

\title{
A Comparison of Energy Expenditures by Elderly and Non-Elderly Households-- 1975 and 1985
}

May 1980

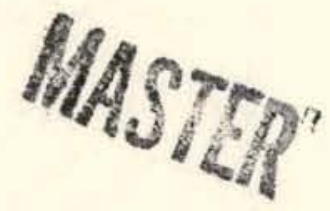

U.S. Department of Energy

Energy Information Administration

Assistant Administrator for Applied Analysis

Washington, D.C. 20461

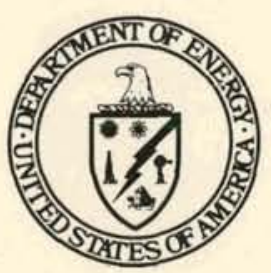




\section{DISCLAIMER}

This report was prepared as an account of work sponsored by an agency of the United States Government. Neither the United States Government nor any agency Thereof, nor any of their employees, makes any warranty, express or implied, or assumes any legal liability or responsibility for the accuracy, completeness, or usefulness of any information, apparatus, product, or process disclosed, or represents that its use would not infringe privately owned rights. Reference herein to any specific commercial product, process, or service by trade name, trademark, manufacturer, or otherwise does not necessarily constitute or imply its endorsement, recommendation, or favoring by the United States Government or any agency thereof. The views and opinions of authors expressed herein do not necessarily state or reflect those of the United States Government or any agency thereof. 


\section{DISCLAIMER}

Portions of this document may be illegible in electronic image products. Images are produced from the best available original document. 


\section{Analysis Report}

\section{A Comparison of Energy Expenditures by Elderly and Non-Elderly Households-- 1975 and 1985}

AR/EUA/80-15

May 1980

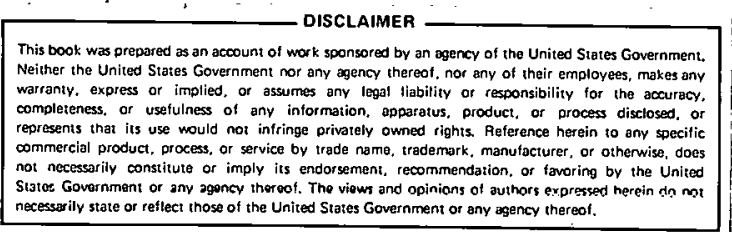

necesserily state or reflect those of the United States Government or any agency thereat.

Prepared by:

Ann Siler

Residential and Commercial Energy Use Division

Office of Energy Use Analysis

U.S. Department of Energy

Energy Information Administration

Assistant Administrator for Applied Analysis

Washington, D.C. 20461

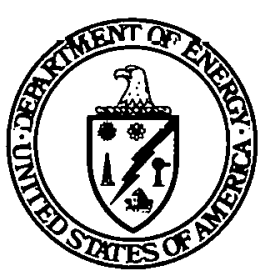

Fur sūle liy the Buperintenclent of Doouments, U.S. Gnvernment. Printinc Ofțce, Waslıington, D.C. 20402 


\section{PREFACE}

This paper was prepared for the Assistant Administrator of Applied Analysis, Energy Information Administration. It continues a series of reports on the impacts of energy expenditures upon various socioeconomic groups of the residential sector.

The author wishes to thank Mark Rodekohr and Gerald Peabody for their advice in the preparation of this report. Thanks also go to Gene Reiser and Ray Fuller for computer assistance and to Hattie Ramseur and Carolyn Jenkins for typing the several drafts of this paper. 
PREFACE

EXECUTIVE SUMMARY

1. INTRODUCTION

2. ENERGY EXPENDITURES BY ELDERLY AND

NON-ELDERLY HOUSEHOLDS--1975 AND 1.985

iv

The 1975 Elderly Household Population

1975 Average Fuel Expenditure Levels

4

Energy Expenditure as a Percentage of Disposable Income

Energy Expenditure on a Per-Person Basic

1975 Household Characteristics and Energy Expenditure

The Projected 1985 Elderly Household Population

Projected 1985 Fuel Expenditure Levels

Projected Energy Ependiture as a Percentage of Disposable Income

Projected Energy Expenditure on a Per-Person Basis 19 1985 Household Characteristics and Projected Energy 19 Expenditure

\section{REFERENCES}

APPENDICES

A. Statistical Tables

B. Statistical Notes

FIGURE

1. Eldorly and Non-Elderly Housuhold Population Percentages by Disposable Income Class--1.975 and 1985 


\section{TABLES}

1. 1975 Average Fuel Expenditure of Household Groups, Expenditure as a Percentage of Disposable Income, and Expenditure on a Per-Person Household Basiș (1978. Dollars)

F

2. 1975 Average Energy Expenditure by Elderly and Non-Elderly Households and Expenditure as a Percentage of Disposable. Income (1978 Dollars)

3. 1975 Average Disposable Incomes of Elderly and Non-Elderly Households (1978 Dollars)

4. Elderly and Non-Elderly Household Population Percentages by Disposable Income Class--1975 and 1985 (1978 Dollars)

5. 1985 Average Fuel Expenditure of Household Groups, Expenditure as a*Percentage of Disposable Income, Expenditure on a Per-Person Household Basis, and Percentage Change from 1975 (1978 Dollars)

6. 1985 Average Energy Expenditure by Elderly and Non-Elderly Households and Expenditure as a Percentage of Disposable Income ( 1978 Dollars)

7. Percentage Change in Average Energy Expenditures of Elderly, Non-Elderly, and All Households--1975 to 1985 (1978 Dollars)

8. 1985 Average Disposable Incomes of Elderly and Non-Elderly Households with Percentage Change from 1975 (1978 Dollars) 


\section{EXECUTIVE SUMMARY}

This report analyzes direct energy expenditure by elderly households (where the head is aged 65 or over). It contrasts their use of home fuels and gasoline with that of non-elderly households.

Energy expenditures for 1975 are compared to projections for 1985 from the midterm Projection Series C prepared by the Energy Information Administration (EIA) for its Annual Report to Congress 1978. Simulations of household energy expenditures and incomes for both years were accomplished using the Micro-Analysis for Transfers to Households/Comprehensive Human Resources Data System--the MATH/CHRDS model. All amounts are expressed in 1978 dollars.

Expenditures for each fuel type are only for households that use that particular fuel. Expenditures cannot be added across all fuels to calculate total expenditures because not all households use all fuels.

The major findings of this report are:

- In 1975, the elderly household's total energy expenditure for home fuels and gasoline is 42 percent less than that of the non-elderly household. This includes 18 percent less for home fuels and 45 percent less for gasoline.

- Elderly incomes in 1975 are 39 percent less than nonelderly incumes. Beciduse bull elderly incumes and expenditures are less, the proportion of elderly incomes expended directly for energy is very similar to that of the non=elderly; in 1975, the elderly spend 9.8 percent of income for energv, onlv one-half a percentage point less than the 10.3 percent spent by the non-elderly.

- Of 1975 total direct energy expenditure, the elderly expend a larger percentage of income for home fuels and a smaller percentage for gasoline than the nonelderly. For all fuela the proportion of income spent by the elderly is slightly less than that of the non-elderly.

- Projected 1985 energy expenditures show a 15 percent increase over 1975 expenditures for both elderly and non-elderly households. The elderly continue to spend 42 percent less than the non-elderly for total fuels, including 20 percent less for home fuels and 15 percent less for gasoline. 
- The major part of increased expenditures in 1985 is for home fuels. Increases in electricity and natural gas prices boost home fuel expenditures for all households. Price and expenditure. increases for other fuels are more modest.

- By 1985, overall incomes increase 21 percent over 1975. Elderly incomes increase 5.9 percent, while non-elderly incomes increase 24 percent. The lower income increase for the elderly leads to an even higher percentage of income spent for all fuels and for home fuels--10.7 and 6.8 percent respectively-exceeding proportions of income spent by the nonelderly --9.6 and 4.4 percent. 


\section{INTRODUCTION}

During the 20th century, the number of older persons in the U.S. population has greatly and rapidly increased. In 1975, elderly persons numbered $22.4 \mathrm{million}$, some 10.5 percent of the total population. The population aged 65 years or older, termed "elderly," increased seven times in number from 1900 to 1975, while the U.S. total population lessthan-tripled from 76.1 million to 213.6 million. The enlarging of the "gerontic" population is expected to continue into the next century, although at a decreasing rate.

This aging of the population represents a long-range demographic shift. Households headed by the elderly now represent more than one-fifth of the household population, and a continued increase of their numbers is expected. Consequently, it is of interest to observe particular socioeconomic characteristics of the group and its consumption of energy and to establish relationships between the two.

This report, therefore, looks at the relative position of the elderly in the population and observes their characteristic use of energy in relation to the total population and to their non-elderly counterparts. Observations are made for 1975 and 1985. The 1985 projections are based on demographic, economic, socioeconomic, and energy data assumptions contained in the Energy Information Administration's (EIA) Annual Report to Congress 1978, Projection Series C. 1

Although the age of the household head is of paramount interest here, there are a multitude of characteristics by which households may be classified. Among these are income, race and sex of household head, and household location. Since the interest is also in fuel use, the types of fuels consumed adds another dimension. Establishing relationships between the large variety of characteristics and energy use can become quite complex.

1 Energy Information Administration, Department of Energy, Annual Report to Congress 1978, Washington, D.C., EIA, 1979, DOETEIA-0173/3 
The model used by the Office of Energy Use Analysis for estimating household energy expenditure is MATH/CHRDS-acronym for Micro-Analysis of Transfers to Households/ Comprehensive Human Resources. Data System. The model represents the residential sector with a large sample of household records in a computer data file. Each household record contains detailed socioeconomic, residence, and energy information and is weighted appropriately so that total records represent the entire U.S. household population for a base year. This data file is then used to project households' future situations with respect to energy use by adjusting the characteristics of each household according to specific assumptions.

By using the 1985 Series C Projections for this report, the resulting MATH/CHRDS data file is the synthetic reprezentation of a large demographic-socioeconomic 1985 survey relating energy use to each household.

S1nce the MATH/CHRDS model, its data requirements, and its methodology, have been extensively described in preyious reports, no further description will be given here. Nor will a descriptive section be included for the 1985 Series C Projection, representing a midterm medium-demand, medium-supply case. For this description, the reader is referred to the EIA's Annual Report to Congress 1978, which al so contains a discussion of the use of MATH/CHRDS.

Classification of a household as "elderly" or "non-elderly" depends solely on the age of the household head. Age 65 or over classifies the household head as elderly and thus also the household. Other household members may be of any age. Non-elderly households are those with a household head aged less than 65.

The following section of this report eompares the use of energy in 1975 by households headed by the elderly with energy use by all households and by the non-elderly household population. A similar analysis follows, using projections to 1985 .

2

See John'M. Brazzel, et al., "A Distributional Analysis of the 1985 Energy Projections rur the Annual Report to Congress of the Encrgy Information Administration", Washington, D.C., Energy Information Administration, June 1978, AM/IA/78-09. 
These analyses are based on extensive MATH/CHRDS crosstabulations of salient household characteristics and household energy use. Characteristics include households' disposable income, poverty status, location by Department of Energy (DOE) region and Standard Metropolitan Statistical Area (SMSA), and razce and sex of the household head as well as age. ${ }^{3}$ Energy use by fuel type will be identified for total home fuels, including electricity, natural gas, bottled gas and fuel oil, and for all fuels, where gasoline use is also included. Throughout the analysis, both income and expenditure dollar amounts for 1975 and 1985 are expressed in constant 1978 dollars.

Appendix A contains the statistical tables forming the data collection on which this report is based; Appendix B contains statistical notes pertinent to those tables.

3 See Appendix A, Table A.63 for DOE regions by state. SMSA location is noted as residence within or residence outside of an SMSA county. SMSAs and their county components are so designated by the Office of Management and Budget, Executive of $\mathrm{f}$ ce of the President. SMSA designation in this report includes an undefined category, used where confidentiality requirements of the Bureau of the Census preclude reporting of certain areas. See Appendix B, Statistical Notes, p. 105 


\section{ENERGY EXPENDITURE BY. ELDERLY AND NON-ELDERLY HOUSEHOLDS- -1975 AND 1985}

The general characteristics of elderly households and their fuel use are first discussed and compared with the rest of the population. Energy expenditure comparisons of elderly households with the rest of the population are then made by level of expenditure, expenditure as a percentage of disposable income, and expenditure per person in the household. Relating energy expenditures to households' disposable incomes measures energy consumption in relation to households' resources for all consumption. Estimating households' energy costs on a per-capita basis presents still another measure of their energy consumption in relation to the rest of the population.

\section{The 1975 Elderly Household Population}

Households headed hy the elderly in 1975 represent 20 percent of the total population of almost 70.5 million households examined in this report. Characteristically, - elderly households have disproportionately low incomes in comparison to the total population. Some 71 percent of their numbers have disposable incomes under $\$ 10,000$, as opposed to 40 percent of the total and 32 percent of the nonelderly. of total households, 12.5 percent are below the poverty level, with 22.5 percent of elderly households and 10 percent of the non-elderly in poverty.

Percentages of elderly households by regional location are similar to those of all households, varying only 1 percentage point above or below DOE regional figures. Elderly households show 4 percentage points more nonmetropolitan residence and exhibit a larger white ratio than natinnally. Forty percent of elderly householda are headed by women, approximately 18 peroentage pointo more than the national proportion of 22 percent. Lower income and the larger number of females heads are two of the most identifiable differences from the norm in the general characteristics of the elderly population.

1 Households analyzed in this report are those with positive disposable income, living in the lower continental Unitad States, and sxponding a positive amount for any fuel included in this report.

2 See Appendix B, Statistical Notes, \# 5, for the poverty level definition. 
The elderly household population closely resembles the total population in the use of specific home fuels. Virtually all households use electricity and over 70 percent use natural gas. A much lower use of gasoline, however, distinguishes elderly households from the average pattern of specific fuel use. While 88 percent of non-elderly households make some use of gasoline, only 65 percent of elderly households do so.

\section{Average Fuel Expenditure Levels}

Table 1 shows the 1975 average fuel expenditure for all households, for elderly households, and for their nonelderly counterparts, by level, by percentage of disposable income, and by expenditure per person in household.

The typical elderly household spends $\$ 517$ for home fuels-about 18 percent less than the $\$ 630$ average for non-elderly households. Most of the lower home fuel expenditure by the elderly is attributable to a less intensive use of electricity. Average electricity expenditure by the elderly is over 31, percent less than that of the non-elderly. This lesser use probably results from a combination of lower incomes and smaller household sizes. Other home fuels al so show lower expenditures by the elderly, ranging from 10.5 percent less than the non-elderly for natural gas to 3.8 percent less for fuel oil.

The greatest difference in fuel expenditure between the elderly and non-elderly is for gasoline. Gasoline is the largest, single energy item in household expenditure for both groups. But elderly households expend $\$ 563$ for gasoline, almost 45 percent less than the non-elderly average of $\$ 1,021$.

The average for all fuel expenditure by elderly households is $\$ 884$, some 42 percent less than that of the non-elderly. Thus, for both home fuels and all fuels, the elderly household's level of energy expenditure is well below that of the non-elderly. 


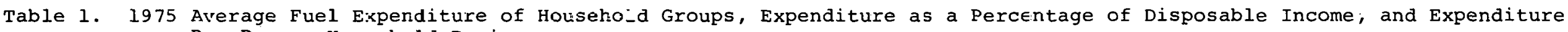
on a Per-Person Househoid Rasis (1978 Dollars)

\begin{tabular}{|c|c|c|c|c|c|c|c|c|c|c|}
\hline & \multicolumn{3}{|c|}{ Expenditure } & \multicolumn{4}{|c|}{$\begin{array}{c}\text { Expenditure as a Percertage } \\
\text { of Disposable Inccre }\end{array}$} & \multicolumn{3}{|c|}{$\begin{array}{c}\text { Expenditure Per Person } \\
\text { in Household }\end{array}$} \\
\hline & $\begin{array}{c}\text { All } \\
\text { Households } \\
\end{array}$ & Elderly & Non-Elcerly & $\begin{array}{c}\text { All } \\
\text { Households }\end{array}$ & Elderly & Non-Elde & $=r y$ & $\begin{array}{c}\text { All } \\
\text { Households }\end{array}$ & Elderly & Non-Elderly \\
\hline \multicolumn{11}{|l|}{ Home Fuels } \\
\hline Electricity & $3 ₫ 0$ & 227 & $3 \Xi \bar{i}$ & 2.3 & 2.5 & 2.2 & & 103 & 123 & 100 \\
\hline Nat'l Gas & 206 & -83 & 210 & 1.5 & 2.0 & 1.4 & . & 69 & 104 & 64 \\
\hline Bottled Gas & 322 & 303 & $32:$ & 2.7 & 4.1 & 2.5 & • & 103 & 157 & 95 \\
\hline Fuel Oil & 444 & $\because 430$ & $44 ?$ & 3.1 & $4.5^{1}$ & 2.9 & & 147 & 233 & 134 \\
\hline Total Home Fuels & 607 & 517 & $630^{\circ}$ & 4.4 & 5.7 & 4.2 & & 201 & 281 & 190 \\
\hline Gasoline & 950 & 563 & 1,021 & 6.3 & 5.2 & 6.5 & & 299 & 271 & 302 \\
\hline Total All Fuels & 1,403 & 884 & $1,53 \equiv$ & 10.2 & 9.8 & 10.3 & & $465^{\circ}$ & 480 & 463 \\
\hline
\end{tabular}

Source: Appendix Tables A.11 through A.16, $\overline{A .23}$ trrough A.25 See Statistical Notes 
Although elderly households spend less on home fuels than do the non-elderly, they spend a larger proportion of their incomes on each specific home fuel than do the non-elderly because the income of the elderly is much lower. An elderly household spends 1.5 percentage points more of its income on. home fuels than does the non-elderly, although the elderly's expenditures are 18 percent lower. Because the elderly own fewer cars and drive fewer miles, however, their gasoline expenditure is almost one-half that of non-elderly households, and a lesser percentage of income than that spent by the non-elderly. Non-elderly total fuel expenditure becomes 10.3 percent of disposable income, only one-half a percentage point above the 9.8 percent of the elderly. The elderly, therefore, spend a larger percentage of income on home fuels and a smaller percentage on gasoline, resulting in near-balance for all fuels.

\section{Energy Expenditure on a Per-Person Basis}

Although the national average of persons per household is 3.02, the average number of persons in an elderly household is 1.84. This relatively low number for the elderly is a result of a decade of increases in maintenance of their own homes and a decline in their living with relatives. ${ }^{3}$ The non-elderly household averages 3.31 persons in size.

The fewer number of persons in the elderly home results in higher per-person expenditure for every specific home fuel. The average $\$ 281$ expended per person by the elderly household for home fuels is almost 50 percent greater than the non-elderly per-person expenditure of $\$ 190$. Average per-person gasoline expenditure by the elderly household is about 10 percent less than that of the nonelderly, but an elderly household's per-person expenditure for all fuels is still about 4 percent higher than the nonelderly's.

3 See United States Bureau of the Census, "Demographic Aspects of $\mathrm{Ag}$ ing and the Older Population in the United States," Current Population Reports: Series P-23, No.59, May 1976, p. 49. 
Classifying energy expenditure by household characteristics points to a considerable variation in energy use which is not apparent when considering national averages. This variation is evident in Table 2, which details both elderly and nonelderly average energy expenditure and expenditure as a percentage of disposable income by seven principal household classifications. Table 3 shows the comparable average disposable incomes of elderly and non-elderly households.

Disposable Income Class

Of the principal classifications, there is greater expenditure variation by disposable income class than any other. Energy expenditure increases dramatically with income. In 1975, households with incomes over $\$ 30,000$ spend 3-4 times that of the lowest income class. For elderly huuseliolds, expenditures for àll f'uels range f'rom 37 percent below the average of $\$ 884$ to 130 percent above. For nonelderly groups, the range is from 43 percent below their average of $\$ 12,533$ to 48 percent above. The larger expenditure variation in all fuels in elderly households is due to a larger variation in gasoline expenditure. Excluding gasoline to show only home fuels expenditure, elderly households show an expenditure pattern very similar to that of the non-elderly, al though at a lower level of expenditure and with somewhat less expenditure variation.

Expressing expenditure as a percentage of disposable income characterizes the regressiveness of energy expenditures. Both elderly and non-elderly households of the lowest income group spend substantially larger proportions of their incomes on fuels than do higher income groups. With disposable inoomes under $\$ 5,000$, elderly and non-eldeily huuschulds spend 13.5 and 14.5 percent of their incomes, respectively, for home fuels. These percentages show a large and immediate decrease as incomes surpass $\$ 5,000$ with gradual decreases, almost equivalent for the two groups, in each income class thereafter. Elderly and non-elderly households in the highest income group expend $11 / 2$ to 2 percent of income on home fuels. In the case of all fuels, percentages of income spent by the elderly are lower than that of the non-elderly, particularly in the lowest groups, reflecting less gasoline expenditure. 


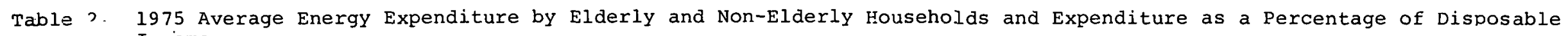
Income

(1978 Dollars)

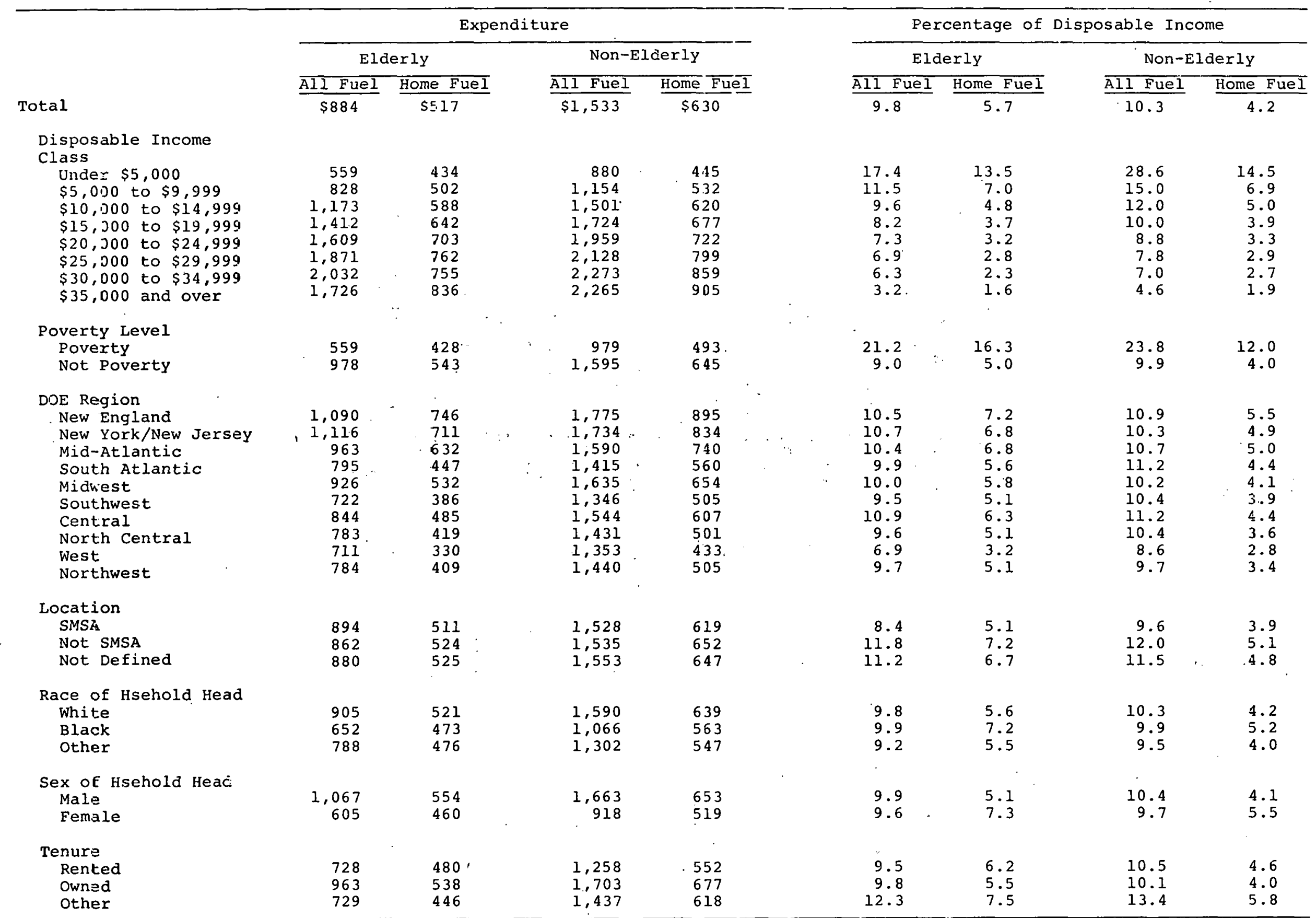

Source: Appendix Tables A.12, A.13, A.24, A.25

See Statistical Notes 
Table 3. 1975 Average Disposable Incomes of Elderly and Non-Elderly Households

(1978 Dollars)

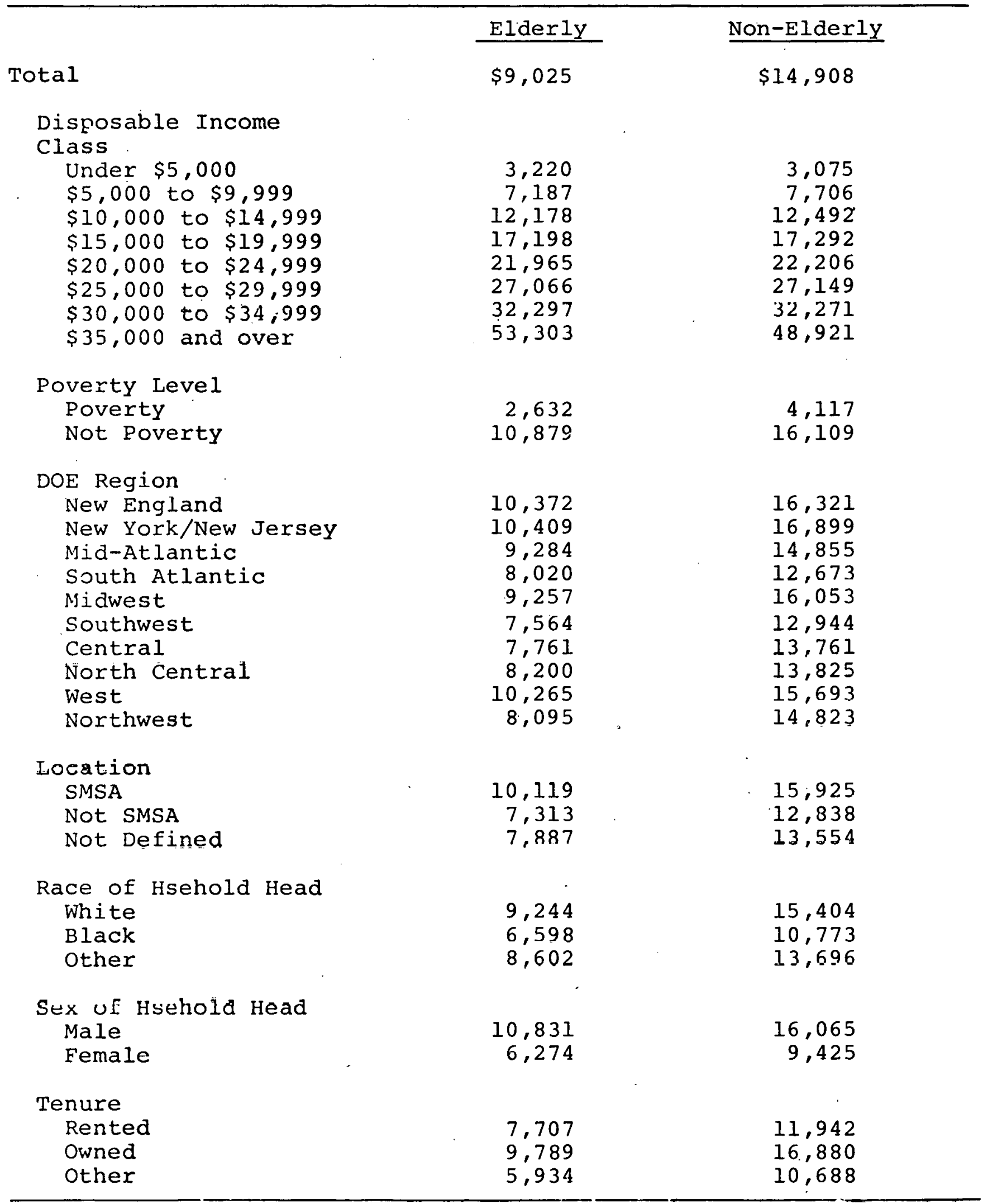

Source: Appendix Tables A.18, A.19

See Statistical Notes 
Poverty level classification of elderly households produces expenditure levels and proportions of income required which closely resemble the situation of the lowest income group, although percentages of disposable income for expenditures are slightly higher.

DOE Regions

Fuel expenditure classified by DOE region indicates the differences in energy costs among various areas. In all regions, the elderly households show substantially lower levels of expenditure than the non-elderly, ranging from $\$ 1,116--36$ percent less--in the New York/New Jersey area, to $\$ 711--47.5$ percent less--in the West. This $\$ 405$ level of variation is close to the $\$ 429$ level of variation of the nonelderly, although it represents greater relative variation from the average for the elderly than for the non-elderly. When considering home fuels only, expenditure of elderly households ranges by region from 15 to 24 percent less than that of the non-elderly. Although the level of home fuel variation is slightly greater than that of all fuels for both elderly and non-elderly households, the relative variation difference between the two groups is smaller. Households of the Northeastern United States (New England, New York/New Jersey, and Mid-Atlantic regions) and the Midwest region spend more for home fuels than any other DOE region. For both elderly and non-elderly households, New England is the region of highest home fuel expenditure, followed by the New York/New Jersey, Mid-Atlantic, and the Midwest regions. New England and New York/New Jersey illustrate a combination of severe winters and relatively higher fuel prices, with electricity, piped gas, bottled gas, and extensively-used fuel oil all near peak prices for the nation as a whole. The contiguous Mid-Atlantic exhibits only slightly lower prices and milder winters. The Midwest, with severe winters, might well rank higher on the expenditure list were not extensively-used natural gas at a relatively low price. The mild west is the region of lowest expenditure, with elderly home ruel average expenditure $\$ 330$ versus $\$ 433$ for the non-elderly. Between these extremes of expenditure (which coincide in terms of ordering elderly/nonelderly expenditure), there is near coincidence for the two groups in the remaining five regions.

Regional ranking by home fuel expenditure expressed as a percentage of disposable income shifts only slightly from the order of regions according to expenditure. In general, high

\footnotetext{
4 See Appendix A, Table A.63 for fuel prices used for this report.
} 
expenditure regions are also high income areas. An exception is the West, which has the lowest energy expenditure but ranks high in income. The net effect of this combination is a relatively very low percentage of disposable income expended for home fuels for both elderly and non-elderly --3.2 and 2.8 percent, respectively. New England and New York/New Jersey have the highest home fuel expenditures accompained by the highest incomes.

Metropolitan Location

Elderly household home fuel expenditure is below that of the non-elderly in both SMSA and non-SMSA areas. Since incomes in non-SMSA areas are smaller, expenditures represent a larger proportion of income than for SMSAs for both elderly. and non-elderly households, though this proportion is larger for the elderly. Non-SMSA elderly spend 20 percent less on home fuels than do the non-elderly, but these expenditures consume 7.2 percent of dispnsahle insome against the 5.1 percent of younger households. The inclusion of gasoline brings expenditures for all fuels for the elderly and nonelderly in non-SMSA areas to almost 12 percent of income.

Race of Household Head

Among the different racial groups, black elderly spend much less than do white elderly for home fuels. However, incomes for black households are almost 29 percent less than for whites, and black elderly households expend 7.2 percent of income for home fuel, 1.5 percentage points above the elderly average, and more than any other racial group. Lesser expenditure for gasoline keeps the elderly black household near the average all-fuel expenditure.

Sex of Homstrumld Head

Since some 40 percent of elderly households are headed by females, versus about 17 percent of the non-elderly, observing fuel expenditure variation by the sex of the household head is of particular interest. Female household heads of both elderly and non-elierly groups spend approximately 43 to 45 percent less for all fuels than male head 3 of the salle gruups. Since female household heads, both elderly and non-elderly, have incomes some 41 to 45 percent below their male counterparts, fuel expenditure as a persentage of income is similar for the two yroups, 9.7 percent for non-elderly females and 9.6 percent for elderly females. There is a greater difference when only home fuels considered. Elderly female heads spend 17 percent less for home fuels than elderly male heads, but this lesser amount represents 7.3 percent of the elderly female income, 2.2 percentage points more than the 5.1 percent of income spent by elderly males. Elderly females also spend 1.8 percentage points more than the 5.5 percent of income spent by nonelderly female heads. 
The Projected 1985 Elderly Household Population 5

Projections for 1985 indicate there will be over 85.8 million households, an increase of 15.3 million over 1975 . Of that total household population, 21.2 percent will be elderly, versus 20 percent in 1975. The increase of 1.2 percentage points represents over $4 \mathrm{million}$ households and brings the elderly household population to 18.2 million.

Elderly household size is projected to decrease from 1.84 to 1.68 persons. This is a relatively smaller reduction, however, than in non-elderly households, which decrease from 3.31 to 2.95 persons.

Disposable incomes rise almost 21 percent overall, but this increase is not evenly distributed. Although average elderly household income shows a 5.9 percent increase from $\$ 9,025$ to $\$ 9,555$ ( 1978 dollars), income of the non-elderly household increases 24 percent, from $\$ 14,908$ to $\$ 18,488$ (1978 dollars). Figure 1 and Table 4 illustrate the percentages of the elderly and non-elderly populations in each disposable income class for 1975 and 1985 .

The distribution of these increased incomes reduces the numbers of non-elderly households in lower income classes and increases their numbers with higher incomes. The result is an obvious flattening of the population/income curve for nonelderly households. The proportion of all elderly households which have incomes under $\$ 10,000$ remains about constant--70 percent in 1985 versus 71 percent in 1975. Non-elderly households with incomes under $\$ 10,000$ represent only 25 percent of their population in 1985 .

5 MATH/CHRDS population projections are based on the Bureau of the Census' Current Population Survey figures. See "Population Estimates and Projections,". Series P-25, Nos.601 and 607 . 
Figure 1. Elderly and Nor-Elderly Household Population Percentages by Disposable Income Class--1975 anc 1985 .

(1978 Dollars)

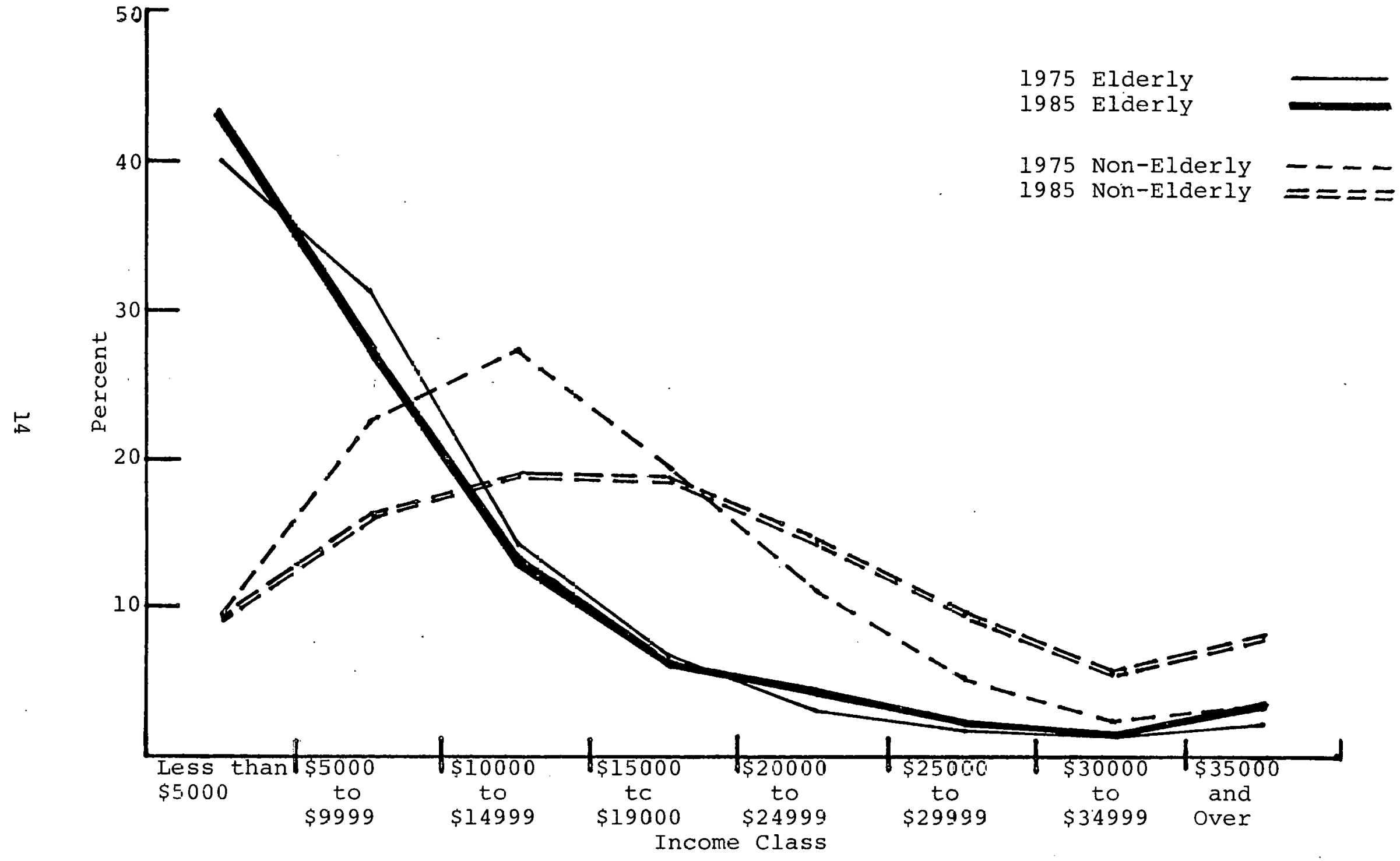

Source: Table 4

See Statistical Notes 
Table 4. Elderly and Non-Elderly Housejold Population Percentages by Disposable Income Class --1975 and 1985 (1978 Dollars)

Total Household Population

$\underline{1975}$
Elderly Household Population

$\underline{1975} \quad \underline{1985}$
Non-Elderly Household population

$\underline{1975}$

$\underline{1985}$

\section{Disposable Income}

Class

$\begin{array}{lrr}\text { Under } \$ 5,000 & 15.5 & 16.4 \\ \$ 5,000 \text { to } \$ 9,999 & 24.2 & 18.4 \\ \$ 10,000 \text { to } \$ 14,999 & 24.4 & 17.6 \\ \$ 15,000 \text { to } \$ 19,999 & 16.8 & 16.1 \\ \$ 20,000 \text { to } \$ 24,999 & 9.4 & 12.0 \\ \$ 25,000 \text { to } \$ 29,999 & 4.6 & 7.9 \\ \$ 30,000 \text { to } \$ 34,999 & 2.2 & 4.6 \\ \$ 35,000 \text { and over } & 2.9 & 7.0\end{array}$

$\begin{array}{rr}39.9 & 43.0 \\ 31.2 & 27.0 \\ 14.2 & 12.9 \\ 6.8 & 6.4 \\ 3.0 & 4.3 \\ 1.8 & 2.2 \\ 1.2 & 1.2 \\ 2.0 & 3.1\end{array}$

9.4
22.5
27.0
19.3
11.0
5.3
2.5
3.1

9.3

3.0

2.9

6.4

2.2

1.2

16.1

18.8

18.7

14.1
9.5

4.6
7.0

5.6

8.0

Source: Appendix Tables A.26 through A.28, A.57 through A.59 See Statistical Notes 
The same proportion of elderly households remains at poverty level, although the number of non-elderly households shows a slight proportionate decrease of 1 percentage point.

Regional and metropolitan locations of elderly households remain substantially the same, as does the racial distribution of household heads.

The most striking change in the elderly household population over the ten-year period is the increase in the proportion of elderly women as household heads in 1985. An increase of over 9 percentage points brings the proportion of elderly female household heads to 49 percent, almost one-half of all elderly households. In contrast, the proportion of female heads in non-elderly households in 1985 rises less than 1 percentage point to 22.3 percent. Thus, lower income and a large proportion of households headed by females continue to be the more identifiable traits of the elderly household population.

The main difference between 1975 and 1985 elderly and nonelderly populations using specific ruels ucuurs ln gasoline use. Proportions of households using gasoline reduce 2.8 percentage points for the elderly, but only about one-half a percentage point for non-elderly households. In 1985, less than 63 percent of the elderly use gasoline, while almost 88 percent of non-elderly households indicate gasoline expenditure.

\section{Projected Average Fuel Expenditure Levels}

Table 5 shows the average fuels expenditure of households projected for 1985. The national average household expenditure for all fuels increases by 15 percent over the 1975 expenditure level. This same percentage increase applies to both elderly and non-elderly households, which now spend $\$ 1,017$ and $\$ 1,766$ respertivoly. Elderly households, thus, continue to expend 42 percent less than do non-elderly.

As in 1975, gasoline is the fuel in which expenditure levels of elderly and non-elderly households show the greatest difference--almost $\$ 500$. Elderly households using gasoline continue to expend 45 percent less than non-elderly. households using gasoline and average gasoline expenditure has risen over 6 percent for both groups, maintaining the 1975 relative consumption pattern. But as noted, fewer elderly houscholds have gosoline expenditure. Car ownership probably becomes more discretionary as energy prices increase vis-a-vis home fuel expenditure, at least for a group which tends to drive less initially. 
Table 5. 1985 Average Fuel Expenditure cf Household Groups, Expenditure as a Percentage of Disposable Income, Expenditure on a Per-Person Holisehold Basis, and Percentage Change from 1975 (1978 Dollaris)

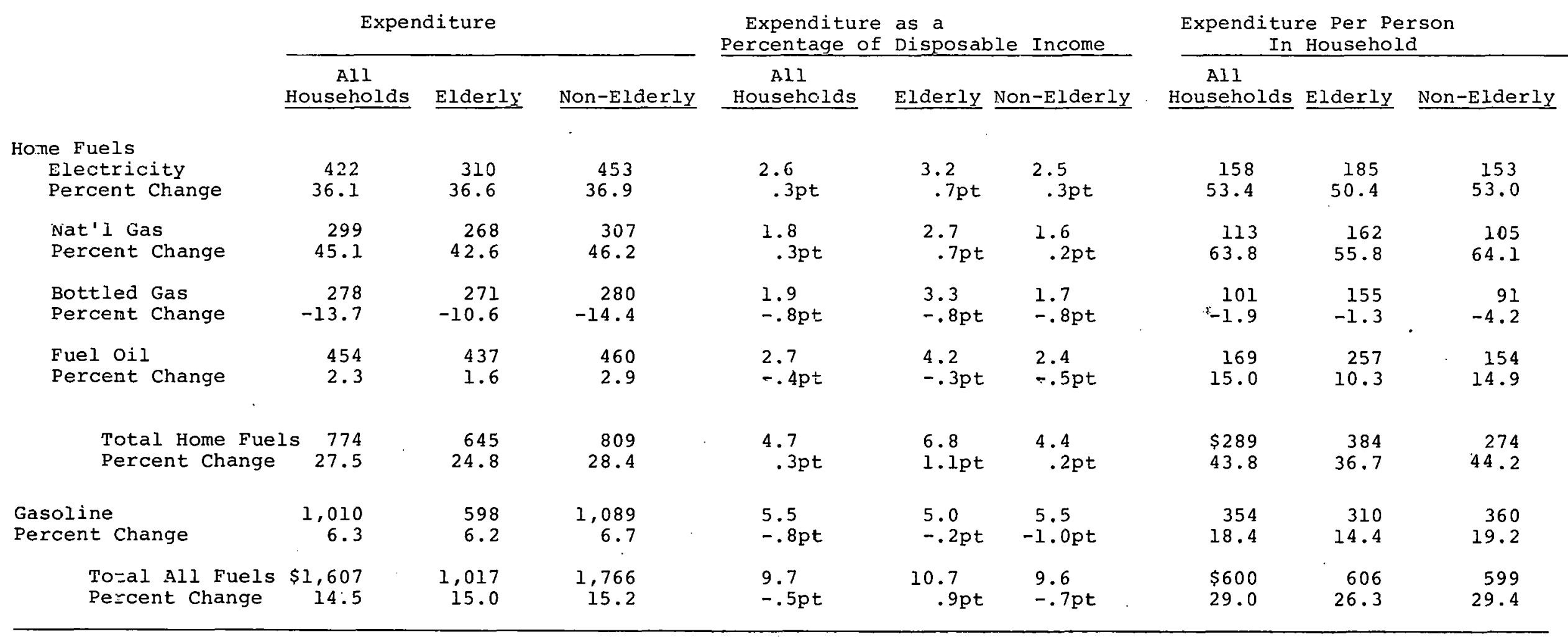

Source: Appendix Tables A.42 through A.47, A.54 through A.56 See Statistical Notes 
Home fuel expenditure in 1985 is projected to increase by a much greater percentage than gasoline for both the elderly and non-elderly. In 1985, elderly household home fuel

expenditure of $\$ 645$ is almost 25 percent more than in 1975 , and is now 20 (rather than 18) percent less than 1985 home fuel expenditure by the non-elderly. This results in part from the greater 28 percent increase in the initially greater 1975 non-elderly home fuel expenditure.

Electricity and natural gas are the major contributors to increased 1985 home fuel expenditures. For both household groups, electricity expenditures increase nearly 37 percent. Natural gas expenditures increase 43 percent for the elderly and 46 percent for the non-elderly. Increases in expenditure for both of these widely-used fuels are predominantly the result of price increases. Electricity price increases well in excess of 20 percent occur over most of the United States, and more wide-spread use of appliances (such as heat pumps or air-conditioners) probably contributes togreater expenditure. Natural gas prices particularly increase--in excess of 100 percent in several regions (due to the Natural Gas Policy Act of 1978). Increases in prices of bottled gas and fuel oil are much more ${ }_{6}$ modest and some areas even show decreases for these fuels.

\section{Projected Energy Expenditures as a Percentage of Disposable Income}

The uneven distribution of the ten-year overall 21 percent increase in average income between elderly and non-elderly households brings about shifts in the percentages of disposable incomes which the two groups spend for fuels. In 1975 , the non-elderly spend a larger percentage of income on all fuels than do the elderly, principally because of much higher gasoline expenditures. But by 1985, the elderly spend a larger proportion of income for all fuels, in spite of essentialiy the same relative expenditure pattern. This is because the elderly receive only a 5.9 percent increase of income as opposed to the 24 percent income increase received by the non-clderly. While the non-elderly income increase is sufficient to counterbalance increased energy expenditure, the smaller increase received by the elderly is not.

6 For more detail on projected price increases for all fuels, the reader is referred to EIA's Annual Report to Congress 1978 
The increased proportion of income expended by the elderly in 1985 is primarily due to greater expenditure for home fuels. Gasoline expenditure as a percentage of income decreases from 1975 to 1985 for both elderly and non-elderly. But the heavy increases noted in electricity and natural gas expenditure raise home fuel expenditure as a proportion of 1985 elderly incomes more than a percentage point to almost 7 percent. On balance, increased home fuel expense combined with the lesser income increase bring the elderly proportion of income for fuel expenditure to almost 11 percent versus the 9.6 percent of the non-elderly.

\section{Projected Energy Expenditure on a Per-Person Basis}

In 1985, expenditure levels per-person in all households rise 29 percent for all. fuels and 44 percent for home fuels. In all cases, with the usual exception of gasoline, the elderly household's per-person expenditure remains greater than the non-elderly's. Relative to the non-elderly, however, the elderly household's per-person expenditure does not increase as much. Whereas the size of all U.S. households decreases, the reduction in size of the nonelderly household--.36 persons--is greater than that of the elderly's--. 16 persons. Per-person expenditure for the nonelderly household, therefore, increases proportionately more, or decreases in the case of bottled gas, than that of the elderly. Greater expenditure for home fuels by the elderly is counterbalanced by greater gasoline expenditure by the non-elderly. The result is an elderly per-person expenditure of $\$ 606$, only slightly over the $\$ 599$ per-person expenditure of the non-elderly for all fuels.

\section{Household Characteristics and Projected Energy Expenditure}

Table 6 shows 1985 average energy expenditure of the elderly and the non-elderly by major household characteristics. Table 7 details the percentage change in expenditures over the len-year period. Table 8 provides the 1985 average disposable incomes for elderly and non-elderly households and percentage changes from 1975.

In 1985, there is continued variation of energy expenditure within disposable income groups, but there is a slight shift. For the elderly, the variation in gasoline expenditure is reduced and lhat of home fuel expenditurc is increased. Elderly high-income groups continue to expend 
Table 6. 1985 Average Energy Expenditure by Elderly and Non-Elderly Households an.l Expenditure as a Percentage of Disposable Income 1978 Dollars)

\begin{tabular}{|c|c|c|c|c|c|c|c|c|}
\hline & \multicolumn{4}{|c|}{ Expenditure } & \multicolumn{4}{|c|}{ Percent of Disposable Income } \\
\hline & \multicolumn{2}{|c|}{ Elderly } & \multicolumn{2}{|c|}{ Non-Elderly } & \multicolumn{2}{|c|}{ Elderly } & \multicolumn{2}{|c|}{ Non-Elderly } \\
\hline & Ali Fuels & Home Fuel & All Fuels & Home Fuel & All Fiels & Home Fuel & All Fuels & Home Fuel \\
\hline Total & $\$ 1,017$ & $\$ 645$ & $\$ 1,766$ & $\$ 809$ & -0.7 & 6.8 & 9.6 & 4.4 \\
\hline $\begin{array}{l}\text { Dispcsable Income } \\
\text { Class } \\
\text { Under } \$ 5,000 \\
\$ 5,000 \text { to } \$ 9,999 \\
\$ 10,000 \text { to } \$ 14,99, \\
\$ 15,000 \text { to } \$ 19,999 \\
\$ 20,000 \text { to } \$ 24,999 \\
\$ 25,000 \text { to } \$ 29,999 \\
\$ 30,000 \text { to } \$ 34,999 \\
\$ 35,000 \text { and over }\end{array}$ & $\begin{array}{r}676 \\
938 \\
1,301 \\
1,562 \\
1,686 \\
2,015 \\
1,934 \\
2,252\end{array}$ & $\begin{array}{r}536 \\
612 \\
718 \\
819 \\
852 \\
1,011 \\
967 \\
1,099\end{array}$ & $\begin{array}{l}1,056 \\
1,279 \\
1,543 \\
1,855 \\
1,935 \\
2,205 \\
2,336 \\
2,546\end{array}$ & $\begin{array}{r}564 \\
642 \\
731 \\
842 \\
882 \\
950 \\
1,001 \\
1,110\end{array}$ & $\begin{array}{r}20.9 \\
-3.1 \\
20.7 \\
8.9 \\
7.6 \\
7.4 \\
5.9 \\
\leq .3\end{array}$ & $\begin{array}{r}16.5 \\
8.6 \\
5.9 \\
4.8 \\
3.8 \\
3.7 \\
3.0 \\
2.1\end{array}$ & $\begin{array}{r}35.6 \\
16.8 \\
12.3 \\
10.7 \\
8.9 \\
8.1 \\
7.2 \\
5.3\end{array}$ & $\begin{array}{r}18.9 \\
8.4 \\
5.8 \\
4.8 \\
4.0 \\
3.5 \\
3.1 \\
2.3\end{array}$ \\
\hline $\begin{array}{l}\text { Poverty Level } \\
\text { Poverty } \\
\text { Not Poverty }\end{array}$ & $\begin{array}{r}666 \\
\mathrm{~L}, 119\end{array}$ & $\begin{array}{l}526 \\
679\end{array}$ & $\begin{array}{l}1,088 \\
1,833\end{array}$ & $\begin{array}{l}595 \\
830\end{array}$ & $\begin{array}{r}25.9 \\
0.7\end{array}$ & $\begin{array}{r}20.5 \\
5.9\end{array}$ & $\begin{array}{r}30.5 \\
9.2\end{array}$ & $\begin{array}{r}16.7 \\
4.2\end{array}$ \\
\hline 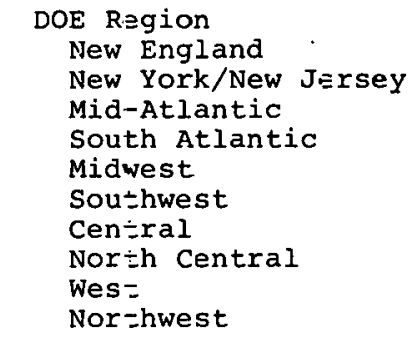 & $\begin{array}{r}1,185 \\
1,278 \\
1,125 \\
955 \\
-, 037 \\
891 \\
923 \\
875 \\
875 \\
859\end{array}$ & $\begin{array}{l}855 \\
870 \\
782 \\
585 \\
650 \\
543 \\
572 \\
520 \\
477 \\
454\end{array}$ & $\begin{array}{l}1,987 \\
1,990 \\
1,874 \\
1,678 \\
1,828 \\
1,645 \\
1,702 \\
1,617 \\
1,607 \\
1,573\end{array}$ & $\begin{array}{r}1,055 \\
1,052 \\
938 \\
729 \\
831 \\
728 \\
729 \\
657 \\
648 \\
556\end{array}$ & $\begin{array}{r}10.7 \\
11.4 \\
11 \\
11 \\
11 \\
10.6 \\
11.3 \\
11.5 \\
10.4 \\
8.1 \\
10.0\end{array}$ & $\begin{array}{l}7.7 \\
7.7 \\
7.7 \\
6.9 \\
6.6 \\
6.9 \\
7.1 \\
6.1 \\
4.4 \\
5.3\end{array}$ & $\begin{array}{r}9.8 \\
9.5 \\
10.0 \\
10.6 \\
9.1 \\
10.2 \\
10.1 \\
9.6 \\
8.4 \\
8.6\end{array}$ & $\begin{array}{l}5.2 \\
5.0 \\
5.0 \\
4.6 \\
4.2 \\
4.5 \\
4.3 \\
3.9 \\
3.4 \\
3.0\end{array}$ \\
\hline $\begin{array}{l}\text { Location } \\
\text { SMSA } \\
\text { Not SMSA } \\
\text { Not Defined }\end{array}$ & $\begin{array}{r}-, 040 \\
985 \\
989\end{array}$ & $\begin{array}{l}651 \\
644 \\
626\end{array}$ & $\begin{array}{l}1,7 \in 1 \\
1,770 \\
1,782\end{array}$ & $\begin{array}{r}810 \\
815 \\
801\end{array}$ & $\begin{array}{r}9.6 \\
12.9 \\
12.0\end{array}$ & $\begin{array}{l}6.0 \\
8.4 \\
7.6\end{array}$ & $\begin{array}{r}8.9 \\
11.1 \\
10.7\end{array}$ & $\begin{array}{l}4.1 \\
5.1 \\
4.8\end{array}$ \\
\hline $\begin{array}{l}\text { Race of Hsehold Head } \\
\text { White } \\
\text { Black } \\
\text { Other }\end{array}$ & $\begin{array}{r}\mathrm{J}, 035 \\
827 \\
977\end{array}$ & $\begin{array}{l}648 \\
611 \\
641\end{array}$ & $\begin{array}{l}1,834 \\
1,277 \\
1,518\end{array}$ & $\begin{array}{l}819 \\
741 \\
722\end{array}$ & $\begin{array}{l}10.6 \\
17.7 \\
10.6\end{array}$ & $\begin{array}{l}6.6 \\
8.7 \\
7.0\end{array}$ & $\begin{array}{l}9.5 \\
9.9 \\
9.1\end{array}$ & $\begin{array}{l}4.3 \\
5.7 \\
4.4\end{array}$ \\
\hline $\begin{array}{l}\text { Sex of Hsehold Head } \\
\text { Male } \\
\text { Femcle }\end{array}$ & $\begin{array}{r}1,282 \\
741\end{array}$ & $\begin{array}{l}708 \\
578\end{array}$ & $\begin{array}{l}1,951 \\
1,123\end{array}$ & $\begin{array}{l}848 \\
673\end{array}$ & $\begin{array}{l}10.4 \\
11.1\end{array}$ & $\begin{array}{l}5.8 \\
8.7\end{array}$ & $\begin{array}{l}9.5 \\
9.9\end{array}$ & $\begin{array}{l}4.1 \\
6.0\end{array}$ \\
\hline $\begin{array}{l}\text { Tenure } \\
\text { Rented } \\
\text { Owned } \\
\text { Other }\end{array}$ & $\begin{array}{r}844 \\
1,115 \\
850\end{array}$ & $\begin{array}{l}538 \\
678 \\
555\end{array}$ & $\begin{array}{l}1,469 \\
1,998 \\
1,681\end{array}$ & $\begin{array}{l}714 \\
885 \\
755\end{array}$ & $\begin{array}{l}10 . .4 \\
10.6 \\
13.9\end{array}$ & $\begin{array}{r}7.2 \\
6.5 \\
.9 .1\end{array}$ & $\begin{array}{r}9.8 \\
9.3 \\
12.9\end{array}$ & $\begin{array}{l}4.8 \\
4.1 \\
5.8\end{array}$ \\
\hline
\end{tabular}

Source: Appendix Tables A.43, A.44, A.55, A. 56 See Statistical Notes 
Table 7. Percentage Change in Average Energy Expenditure of Elderly, Non-Elderly and All Households--1975 to 1985

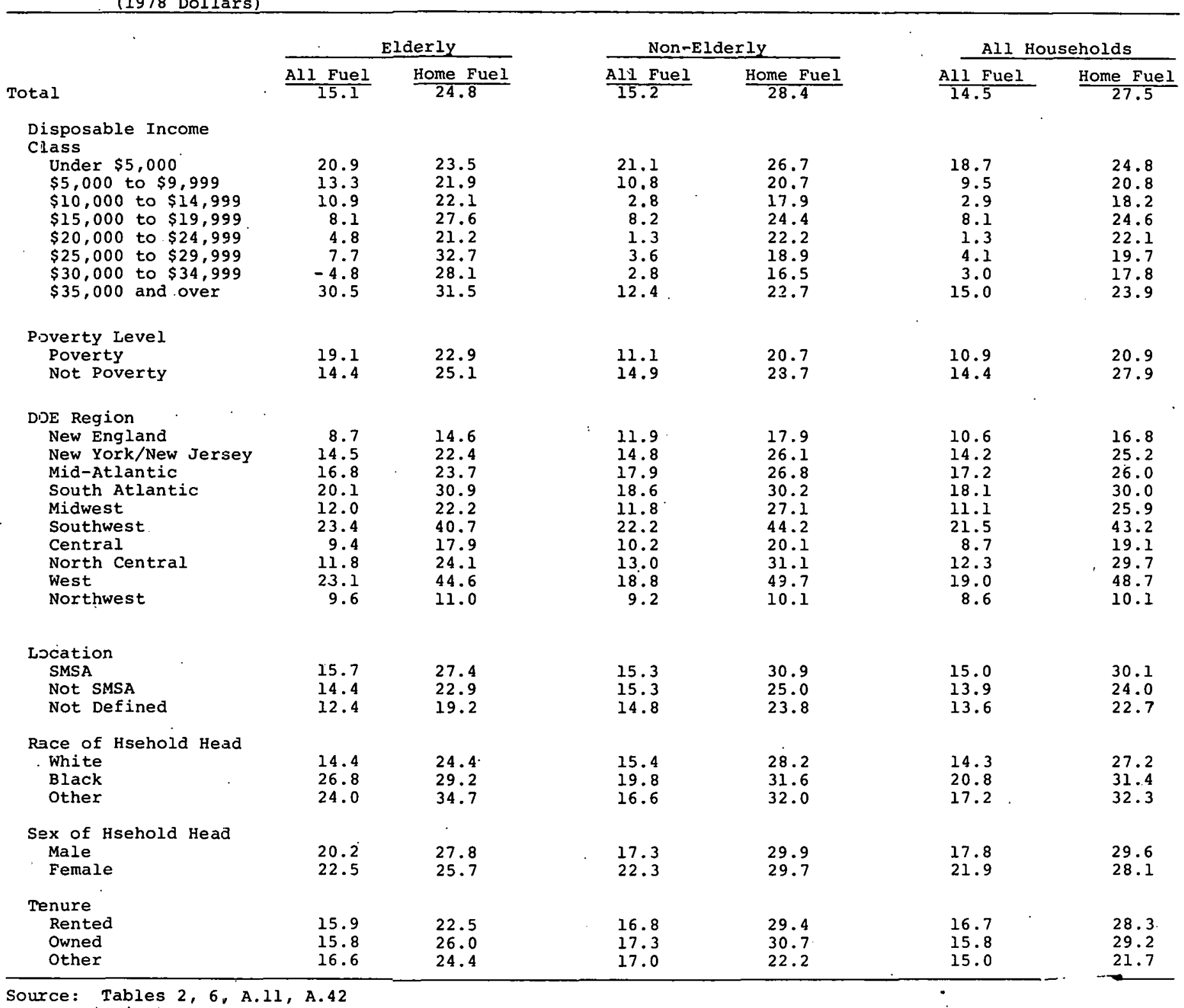

Source: Tables 2,6, A.11, A. 42

See Statistical Notes 


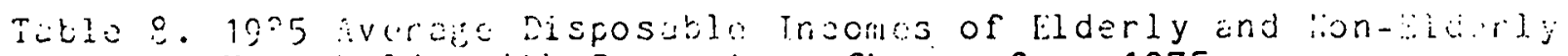
Households with Percentage Change from 1975

(1078 Dollars)

$\begin{array}{cccc}\text { Elderly } & 1985 \text { Income } & \text { Pon-Elderly } \\ \text { Total } & 0.555 & \$ 18,488 & \text { Elderly }\end{array}$

\footnotetext{
Disposable Incoino

\section{Class}

Under $\$ 5,000$

$\$ 5,000$ to $\$ 9,993$

$\$ 10,000$ to $: 11,999$

$\$ 15,000$ to $\$ 19,999$

$\$ 20,000$ to $\$ 24,999$

$\$ 25,000$ to $\$ 29,999$

$\$ 30,000$ to $\$ 34,999$

$\$ 35,000$ and over
}

3,240
7,142
12,152
17,209
22,251
27,251
$32,7 \leq 5$
52,713

2,991

7,520

12,515

17,440

$22,3 ? 9$

27,340

32,269

47,813

2,569

11,578

Not Poverty

\section{DOE Region}

New Engl and

New York/liew Jersey

Mid-Atlantic

South Atlantic

Midwest

Southwest

Central

North Central

West

Northwest

Location

SMSA

Not SMSA.

Not Lefined

Race of Hsehold Head

white

Black

Other

Sex of Hsehold Head

Male

Female

11,095

11,240

10,154

8,453

9,796

7,922

8,013

9,457

10,768

3,571

3,563

19,955

20,295

21,010

18,754

15,775

20,026

16,075

16,849

16,863

19,200

18,385

10,785

7,672

8,275

19,734

15,932

15,683

$9,77 ?$

7,055

19,250

12,946

16,615

12,306
6,674

20,550

11,295

13.6
6.4

6.6

4.9

4.9

$23 . c$

24.1

23.1

Tenure

Rented

Owned

other

$\begin{array}{rr}9,129 & 14,975 \\ 10,482 & 21,458 \\ 6,115 & 13,038\end{array}$

5.5

7.1

3. 1
27.9

25.0

20.2

2.1.

6.9

6.7

19.5

25.4

ล? 1

2.2 .0

Source: Appendix Tables A.49, A,50, A.13, A.19 See Statistical Notes 
about twice the amount of the lowest income groups for home fuels and some three times the amount for all fuels. But as a percentage of income, the burden of energy expenditure in 1985 increases for the lower income classes, both elderly and non-elderly. The elderly with incomes under $\$ 5000$, representing 43 percent of the elderly household population, spend 3 percentage points more than in 1975 for both all fuels and home fuels, while non-elderly households of the same income class suffer the greatest increase of 7 percentage points for all fuels. Income groups over $\$ 10,000$ experience about a 1 percentage point increase or less. The situation of poverty groups is similar to that of the lowest income group, although more severe for the elderly and somewhat less severe for the non-elderly.

In 1985, New England, New York/New Jersey, the Mid-Atlantic, and Mid-West regions, in order, continue to show the highest levels of fuel expenditure for both elderly and non-elderly households. Increases in expenditures for all fuels for all households vary by region from a low of 8.6 percent to 21.5 percent. The largest percentage increases occur in home fuels in the Southwest and West regions and the smallest in the Northwest. Since the Northwest region in 1975 shows relatively low expenditure and receives the smallest increase, it becomes the region of lowest expenditure in 1985, replacing the West region which shows high increases. In the Southwest, increases are sufficiently large to remove it from a lower-expenditure category. Except for these changes, the regional expenditure pattern of both the elderly and non-elderly remains about the same.

There is virtually no change in the ranking of regions by disposable income in 1985. For both the elderly and nonelderly, New York/New Jersey, New England, and the West or Midwest are the highest income areas, while the south Atlantic, Central, and Southwest remain those of lowest income. Because expenditure increases occur unevenly, however, there are some changes in ranking regions by fuel expenditure as a percentage of disposable income. For the elderly, the Central and New York/New Jersey regions continue to require the highest proportions of income for all fuels. Expenditure increases in the South Atlantic and Southwest regions now bring these to third and fourth places. All of these regions in 1985 require over 11 percent of elderly incomes for all fuels. The West remains the lowest region with respect to percentage of income required for all fuels, with 8.1 percent. Considering home 
fuels alone, regions ordered by high-to-low proportions of income spent have about the same ranking as when ordered by high-to-low level of expenditure. An exception for the elderly is the Midwest, where above-average incomes bring average expenditure to a less-than-average proportion of income. For every region, there is a varying increase in expenditure as a percentage of disposable income for the elderly up to 1.8 percentage points, while the non-elderly experience both increases and decreases, all about 1 percentage point or less.

In 1985, the elderly located in metropolitan areas show higher expenditure, both for all fuels and for home fuels, than do elderly households located outside of SMSAs, although the difference is small. But income differences cause fuel expenditure as a percentage of income to be greater in the non-metropolitan areas lhan in SMSAs. Elderly households within SMSAs continue fuel expenditure of smaller income proportion than the national average of the elderly of 10.7 percent, whereas those outside of SMSAs expend 12.9 percent, over 2 percentage points more than the elderly average.

Black and other non-white elderly have larger increases in expenditure by 1985 , so the amount of variation in expenditures between elderly racial groups is reduced. Black incomes, however, are some 28 percent less than those of whites, the racial group with the highest income, and blacks continue to expend significantly higher percentages of income for fuels.

In 1985, elderly households headed by females continue to spend 42-43 percent less for fuels than those headed by elderly males, representing little proportionate change from 1975. But elderly females, whose 1275 incomes are well below the elderly average, experience an income increase of only 6.4 percent by 1985, while elderly males and both nonelderly groups show income increases from 13.6 to 27.9 . percent. The small income increase of elderly females is far outweighed by energy expenditure increases in excess of 20 percent, and the position of elderly females regarding proportions of income for fuel expenditure thus deteriorates. That of other groups improves or stays about the same, since they have received larger income increases serving to balance increased energy expenditures. 
The situation of elderly households headed by females is a heightened example of the probable impacts of fuel price increases upon elderly households in general. Although there are many determinants of energy expenditure, income is clearly of chief importance: Although there are elderly households in all income classes, the bulk of the elderly household population is of lower income, with indications that its income sources are not of readily increasing types. For lower-income groups, both elderly and non-elderly, increasing energy costs unmatched by increasing disposable incomes worsens their relative positions in the future. 
1. John M. Brazzel, et al., A Distŕributional Analysis for the 1985 Energy Projections for the Annual Report to Congress of the Energy Information Administration, Washington, D.C., Energy Information Administration, June 1978, AM/IA/. . $78-09$.

2. Leon J. Hunter, et al., Distributional Analysis of Trends in Energy Expenditure by Black Households, Washington,. D.C., Energy Information Administration, January 1980, $\mathrm{AR} / \mathrm{IA} / 80-07$.

3. Bureau of the Census, Demographic Asects of Aging and the Older Population in the United SEates, Current Population Report: Special Studies: Series P.23 No.59, May 1976.

4. Energy Information Administration, Annual Report to Congress 1978, Washington, D.C., EIA, June 1979, DOE/EIAT-0173-3.

5. Jill A. King, "The Distributional Impact of Energy Policies: Development and Application of the Phase 1 Comprehensive Human Resources Data System, final report to the Department of Energy, Washingtion, D.C., Mathematica Policy Research, June 1977.

6. Residential Energy Consumption by Functional

End Use in 1975, final report to the Department of Energy, Washiligiur, D.C., Mathematı́a Holıcy Research, November 1979 .

7. David Platt, et el., Documentiation of the revised 1974 and, 1977 CHRDS Files, report to the Department, of Ferey Washington, D.C., Mathematica Policy Research, January 1978. 


\section{APPENDIX A \\ List of Tables}

A. 1 Numbers of Households Purchasing Various Fuels--1975

A.2 Numbers of All Households Purchasing Particular Fuels--1975

A. 3 Numbers of Elderly Households Purchasing Particular Fuels-1975

A. 4 Numbers of Non-Elderly Households Purchasing Particular Fuels--1975

A.5 Numbers of Persons in All Households, Purchasing Particular Fuels- -1975

A. 6 Numbers of Persons in Elderly Households Purchasing

Particular Fuels--1975

A.7 Numbers of Persons in Non-Elderly Households Purchasing

Particular Fuels--1975

A.8 Average Numbers of Persons in All Households Purchasing

Particular Fuels--1975

A.9 Average Numbers of Persons in Elderly Households Purchasing Particular Fuels--1975

A. 10 Average Numbers of Persons in Non-Elderly Households

Purchasing Particular Fuels--1975

A. 11 Average Fuel Expenditure of All Households Purchasing Particular Fuels--1975 (1978 Dollars)

A. 12 Average Fuel Expenditure of Elderly Households Purchasing Particular Fuels--1975 (1978 Dollars)

A. 13 Average Fuel Expenditure of Non-Elderly Households Purchasing Particular Fuels--1975 (1978 Dollars)

A. 14 Per Person Average Fuel Expenditure of All Households

Purchasing Particular Fuels--1975 (1978 Dollars)

A. 15 Per Person Average Fuel Expenditure of Elderly Households

Purchasing Particular Fuels--1975 (1978 Dollars)

A. 16 Per Person Average Fuel Expenditure of Non-Elderly

Households Purchasing Particular Fuels--1975 (1978

Dollars) 
A. 17 Average Disposable Income of All Households Purchasing Particular Fuels--1975 (1978 Dollars)

A.18 Average Disposable Income of Elderly Households Purchasing Particular Fuels--1975 (1978 Dollars)

A:19 Average Disposable Income of Non-Elderly Households Purchasing Particular Fuels--1975 (1978 Dollars)

A.20 Per Person Average Disposable Income of All Households Purchasing Particular Fuels--1975 (1978 Dollars)

A.21 Per Person Average Disposable Income of Elderly Households Purchasing Particular Fuels--1975 (1978 Dollars)

A.22 Per Person Average Disposable Income of Non-Elderly Houscholds Purchasing Particular Fuels--1975 (1978 Dollars)

A.23 Average Fuel Expenditure of A11 Households as a Percentage of Disposable Income--1975

A.24 Average Fuel Expenditure of Elderly Households as a Percentage of Disposable Income--1975

A. 25 Average Fuel Expenditure of Non-Elderly Households as a Percentage of Disposable Income--1975

A.26 Percentages of All Households by Specific Characteristics by Type of Fuel Used--1975

A.27 Percentages of Elderly Households by Specific Characteristics by Type of Fuel Used--1975

A. 28 Percentages of Non-Elderly Households by Specific Characteristics by Type of Fuel Used--1975

A.29 Percentages of All Households by Specific Fuels Used by Characteristic- -1975

A. 30 Percentages of Ederly Households by Specific Fuels Used by Characteristic- -1975

A.31 Percentages of Non-Elderly Households by Specific Fuels Used by Characteristic-- 1975

A. 32 Numbers of Households Purchasing Various Fuels--1985

A.33 Numbers of All Households Purchasing Particular Fuels-1985

A.34 Numbers of Elderly Households Purchasing Particular Fuels-1985

A.35 Numbers of Non-Elderly Households Purchasing Particular Fuels--1985 
A. 36 Numbers of Persons in All Households Purchasing Particular Fuels--1985

A.37 Numbers of Persons in Elderly Households Purchasing

Particular Fuels--1.985

A.38 Numbers of Persons in Non-Elderly Households Purchasing Particular Fuels--1985

A.39 Average Numbers of Persons in. All Households Purchasing Particular Fuels--1985

A. 40 Average Numbers of Persons in Elderly Households Purchasing Particular Fuels--1985

A.41 Average Numbers of Persons in Non-Elderly Households Purchasing Particular Fuels--1985

A. 42 Average Fuel Expenditure of All Households Purchasing Particular Fuels--1985 (1978 Dollars)

A.43 Average Fuel Expenditure of Elderly Households Purchasing Particular Fuels--1985 (1978 Dollars)

A.44 Average Fuel Expenditure of Non-Elderly Households Purchasing Particular Fuels--1985 (1978 Dollars)

A. 45 Per Person Average Fuel Expenditure of All Households Purchasing Particular Fuels--1985 (1978 Dollars)

A. 46 Per Person Average Fuel Expenditure of Elderly Households Purchasing Particular Fuels--1985 (1978 Dollars)

A. 47 Per Person. Average Fuel Expenditure of Non-Elderly Households Purchasing Particular Fuels--1985 (1978 Dollars)

A.48 Average Disposable Income of All Households Purchasing Particular Fuels--1985 (1978 Dollars)

A.49 Average Disposable İncome of Elderly Households Purchasing Particular Fuels--1985. (1978 Dollars)

A. 50 Average Disposable Income of Non-Elderly Households Purchasing Particular Fuels--1985 (1978 Dollars)

A.51 Per Person Average Disposable Income of All Households Purchasing Particular Fuels--1985 ( 1978 Dollars)

A.52 Per Person Average Disposable Income of Elderly Households Purchasing Particular Fuels--1985 (1978 Dollars)

A.53 Per Person Average Disposable Income of Non-Elderly Households Purchasing Particular Fuels--1985 (1978 Dollars) 
A.54 Average Fuel Expenditure of All Households as a Percentage of Disposable Income--1985

A.55 Average Fuel Expenditure of Elderly Households as a Percent of Disposable Income--1985

A.56 Average Fuel Expenditure of Non-Elderly Households as a Percentage of Disposable Income--1985

A.57 Percentages of All Households by Specific Characteristics by Type of Fuel Used--1985

A.58 Percentages of Elderly Households by Specific Characteristics by Type of Fuel Used--1985

A.59 Percentages of Non-Elderly Households by Specific Characteristics by Type of Fuel Used--1985

A.60 Percentages of All Households by Specific Fuels Used by Characteristic- -1985

A.61 Percentages of Elderly Households by Specific Fuels Used by Characteristic- -1985

A.62 Percentages of Non-Elderly Households by Specific Fuels Used by Characteristic- -1985

A.63 Department of Energy Regions by State and Energy Prices by Fuel Type--1975 and 1985 (1978 Dollars) 


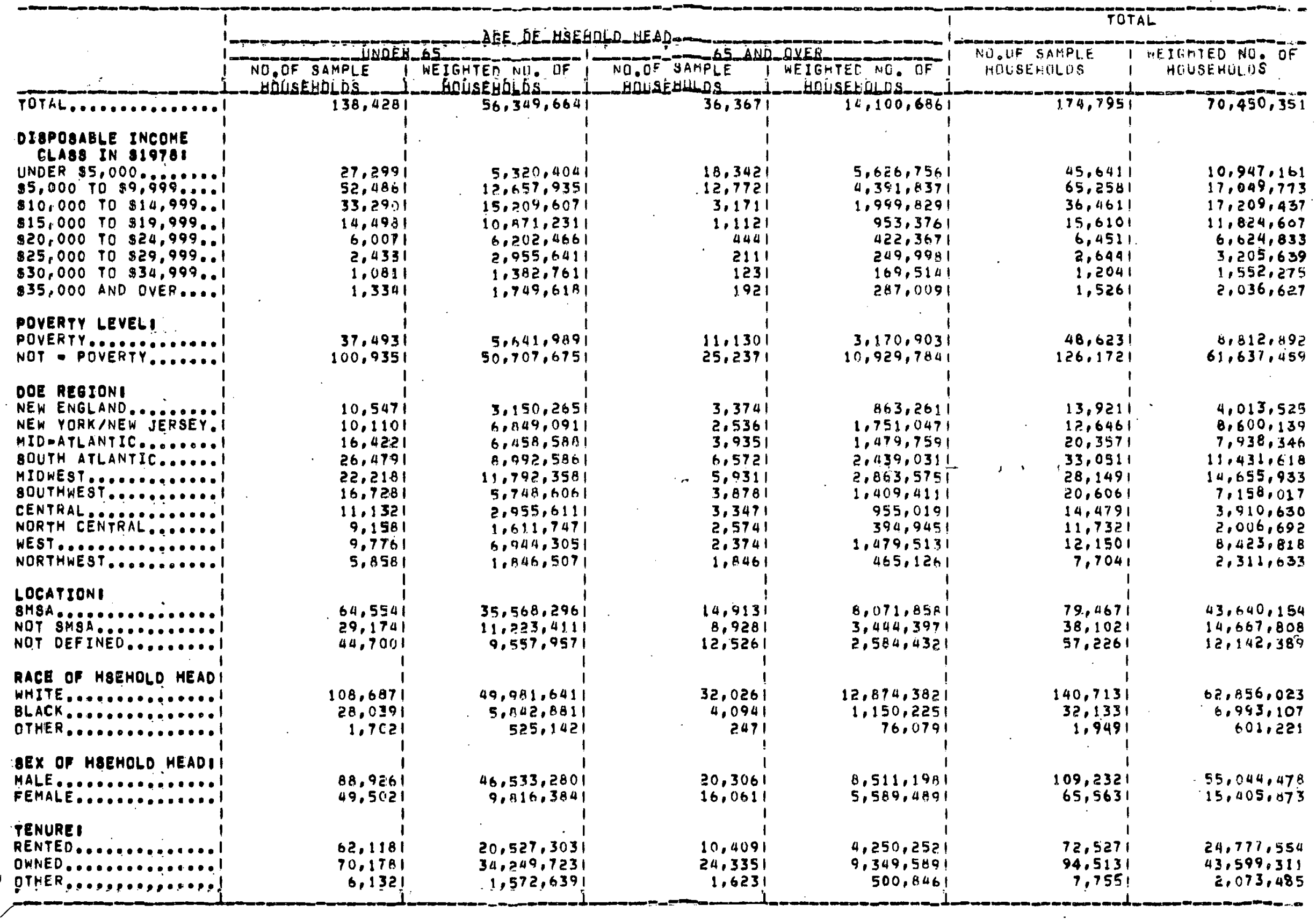




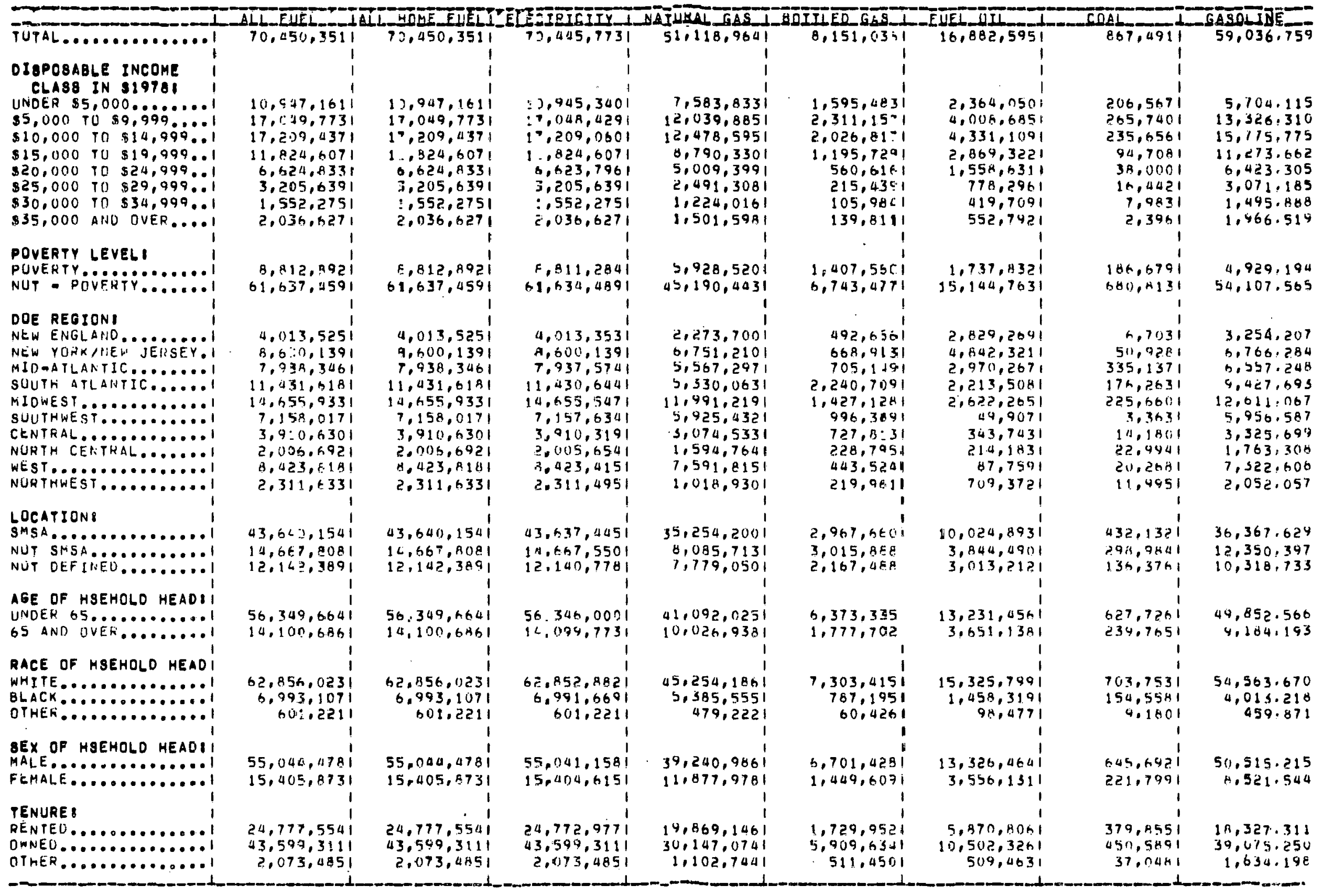


NUMBERS OF ELOERLY HOUSEHOLOS PURCHABIMO PARTICULAR PUELSMOITYS

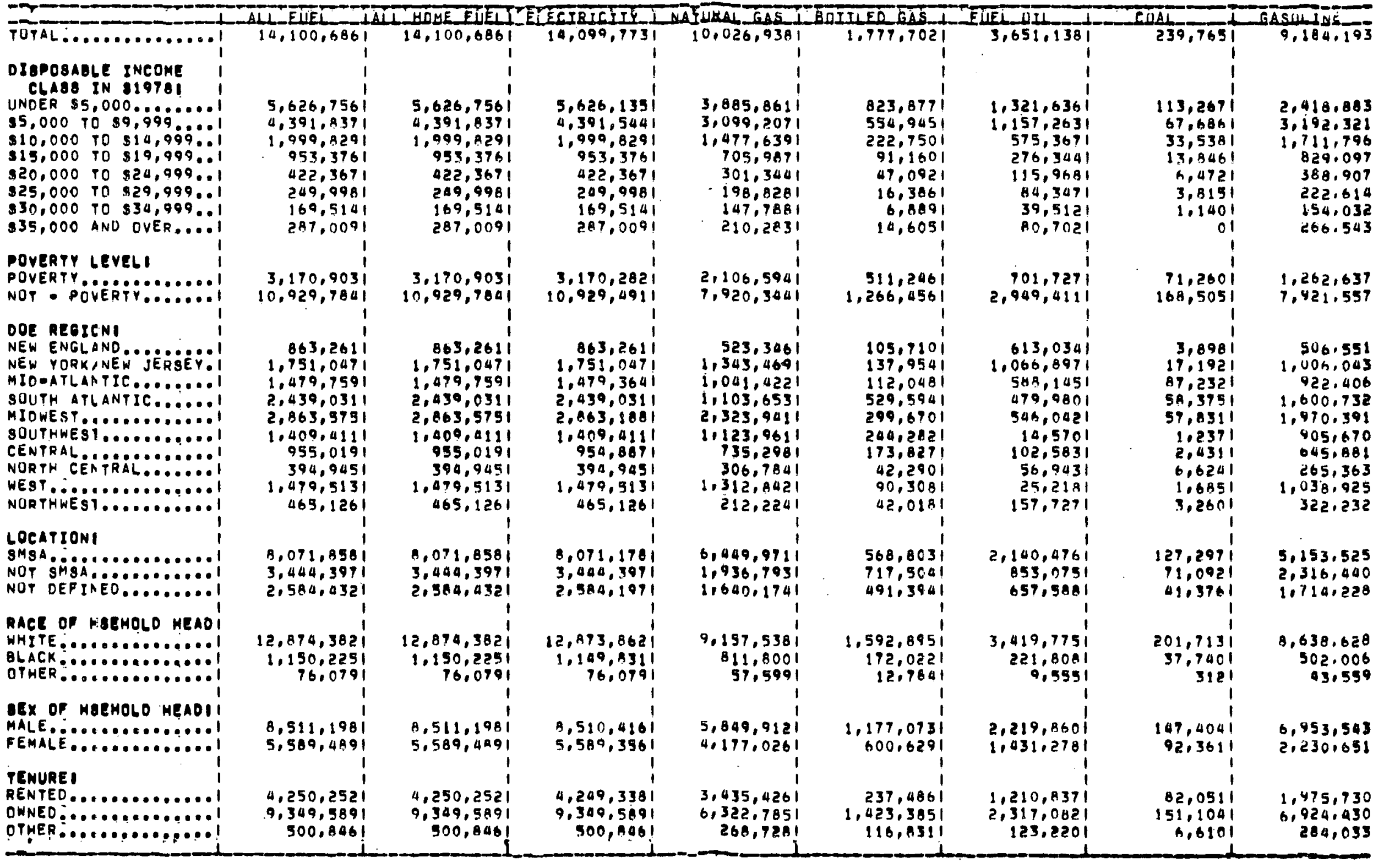

SEE STATISTICAL NOTES 


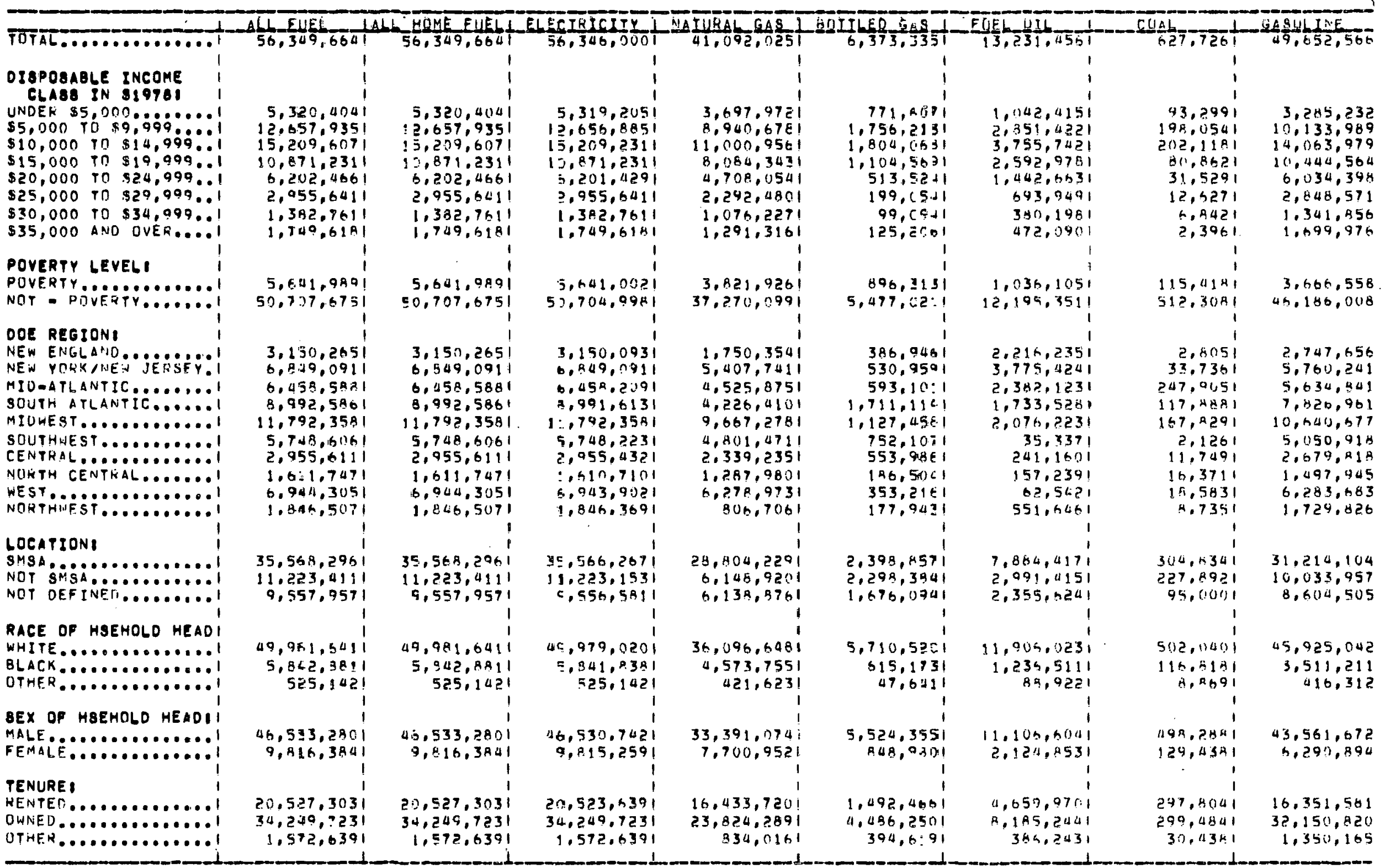




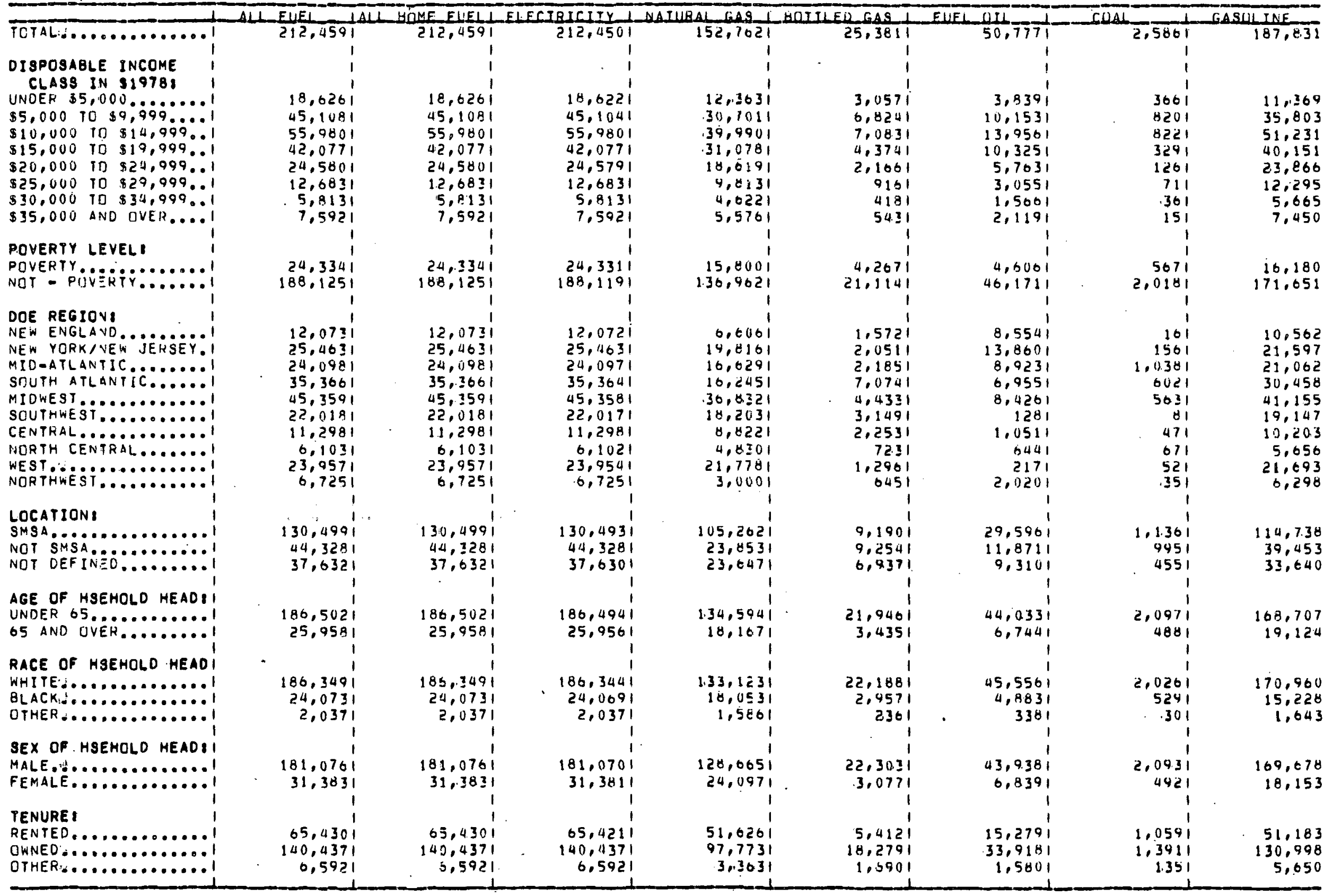

SEE STATISTICAL NOTES 


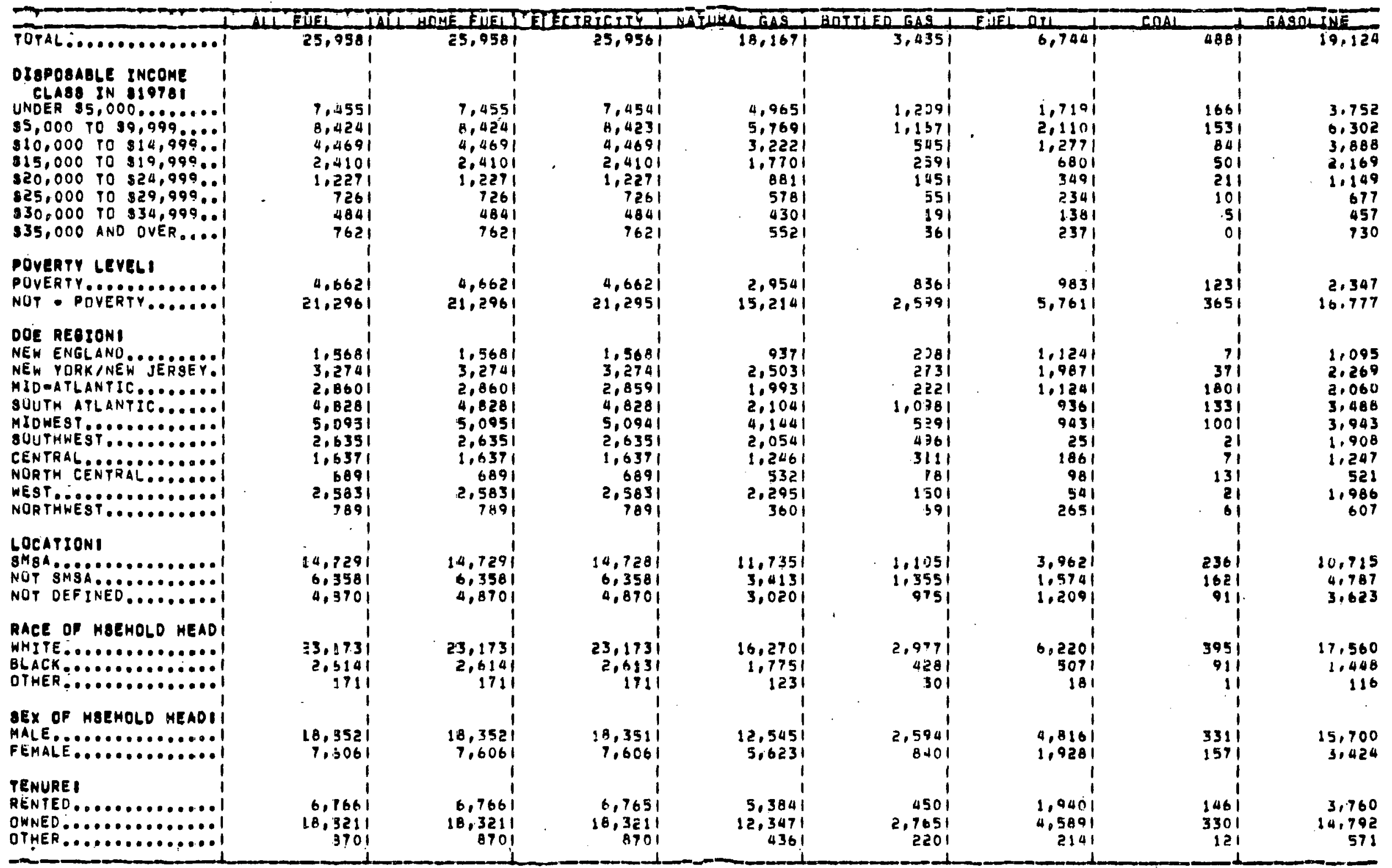

SEE STATISTICAL NOTES 
MUMBERS OF PERBONS IN NONGELDERLY HOUSEHOLDS PURCHASING PARTICULAR FUELSEIITS (IN THOUSANDS)

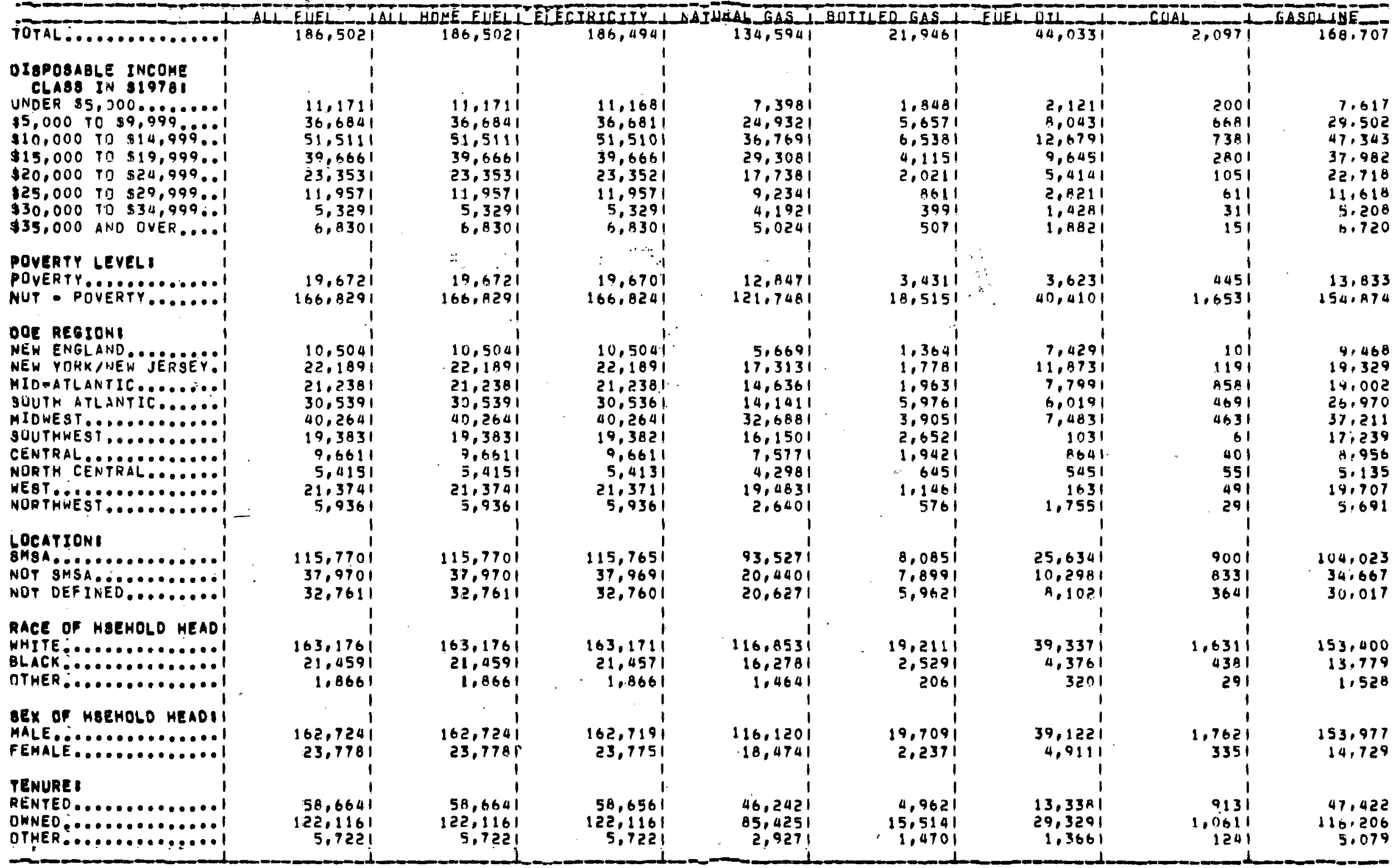

SEE STATISTICAL NOTES 
TABLE A. 8

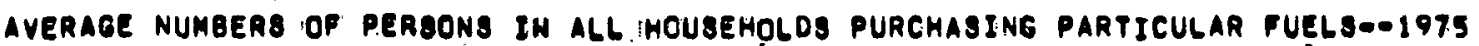

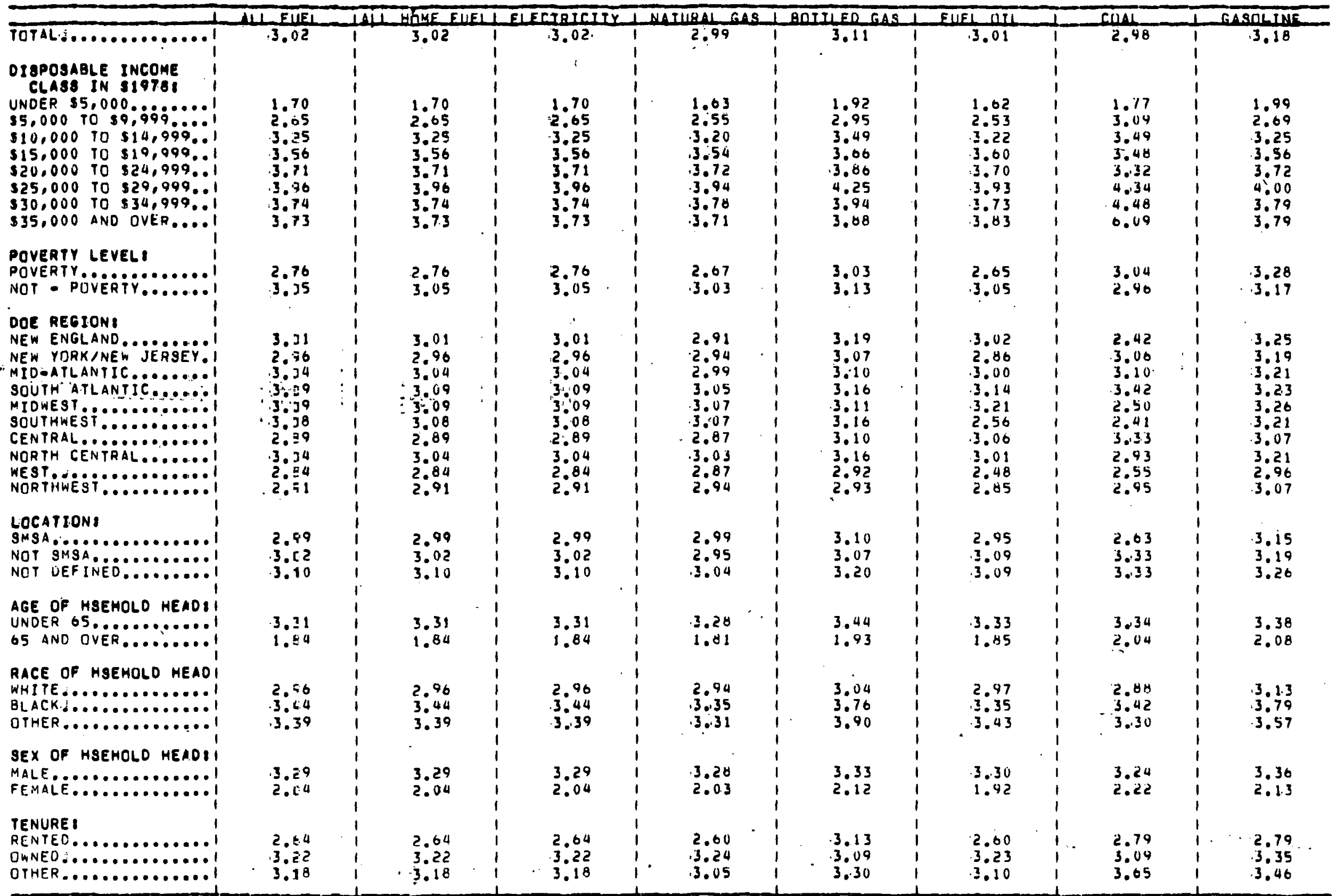

SEE SI - ITICAL NOTES 
TABLE A. $y$

AVERAGE NUMBERS OF PERBONB IN ELOERLY MOUSEHOLDS PURChASING PARTICULAR FUELBe-1979

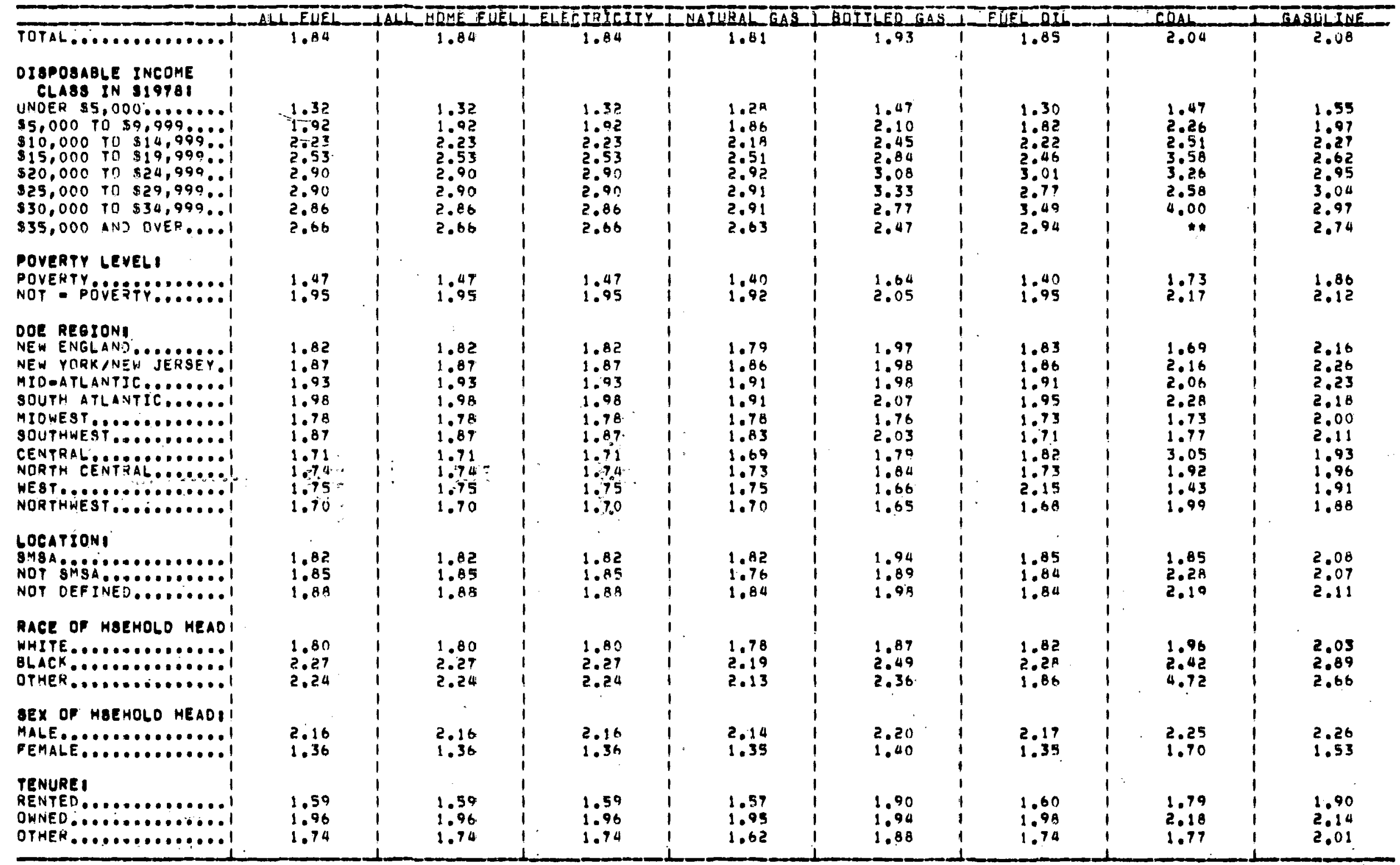

SEE STATISTICAL NOTES 
TABLE A. 10

AVERAGE NUMBERS OP PERSONS. IN NONGELOERLY HOUSEHOLDS FURCHASING PART!CULAR FUELSEOI9TS

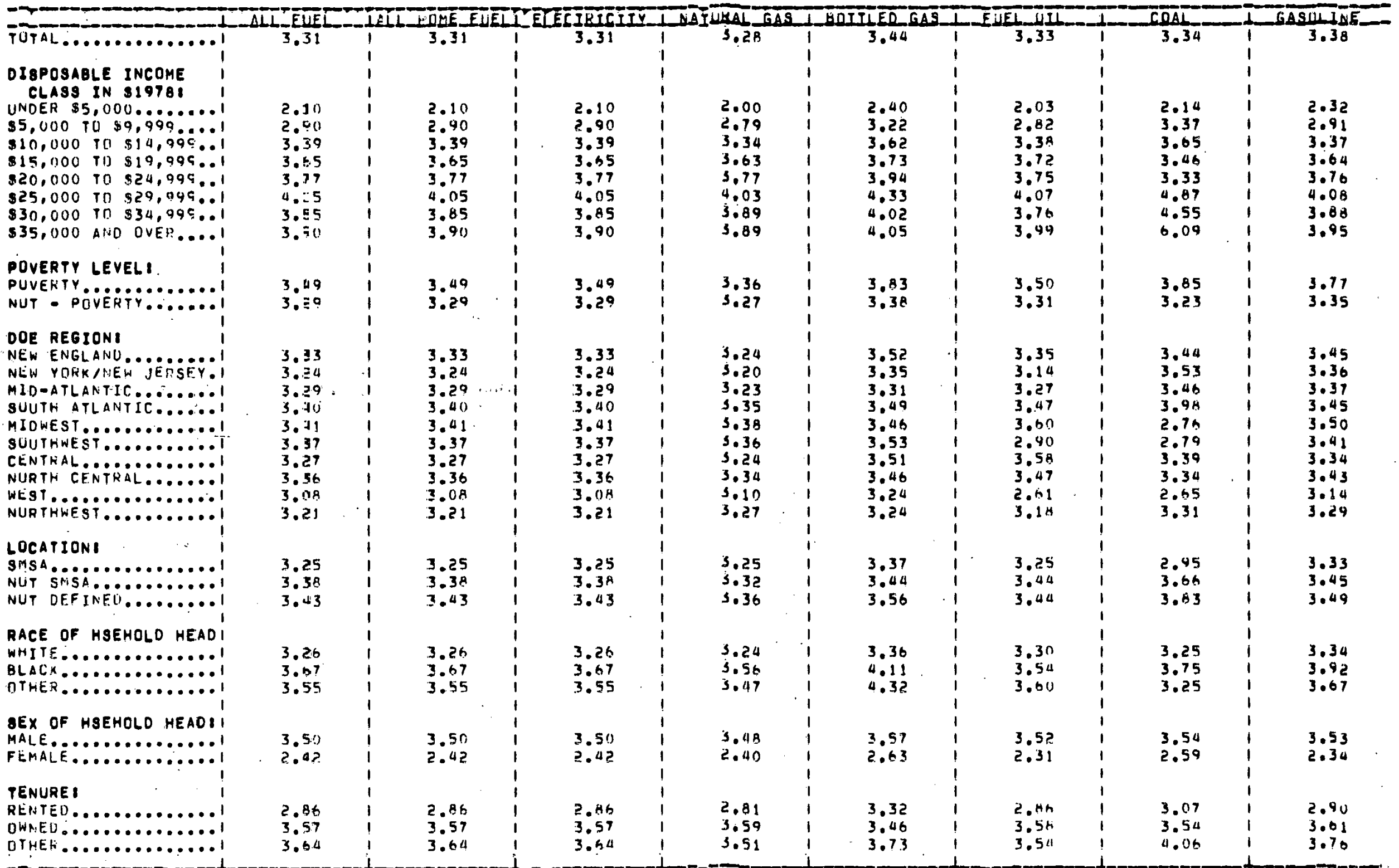

SEE STATISTICAL NOTES 
TABLE 1

AVERAC- . UEL EXPENDITUFE OF ALL HOUSEHOLDS PURCHASING PARTICULAR FUELS-91975 (IN 1978 S9)

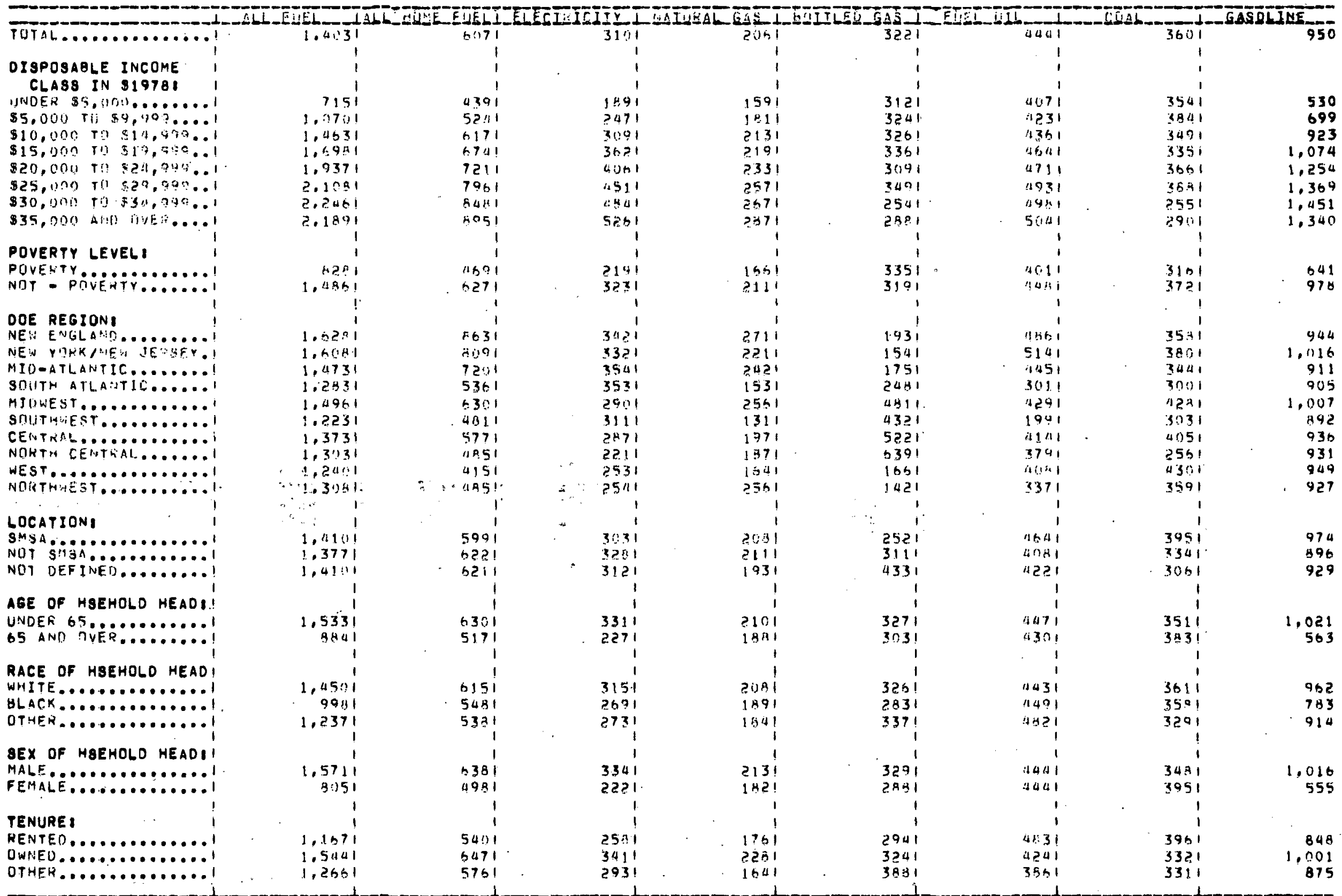

SEE STATISTICAL NOTES 
TABLE A. 12

AVERAGE PUEL EXPENDITURE OP ELEERLY MOUSE-OLDS PURCHASING PARTICULAR FUEL8001975 (IN 1978 88)

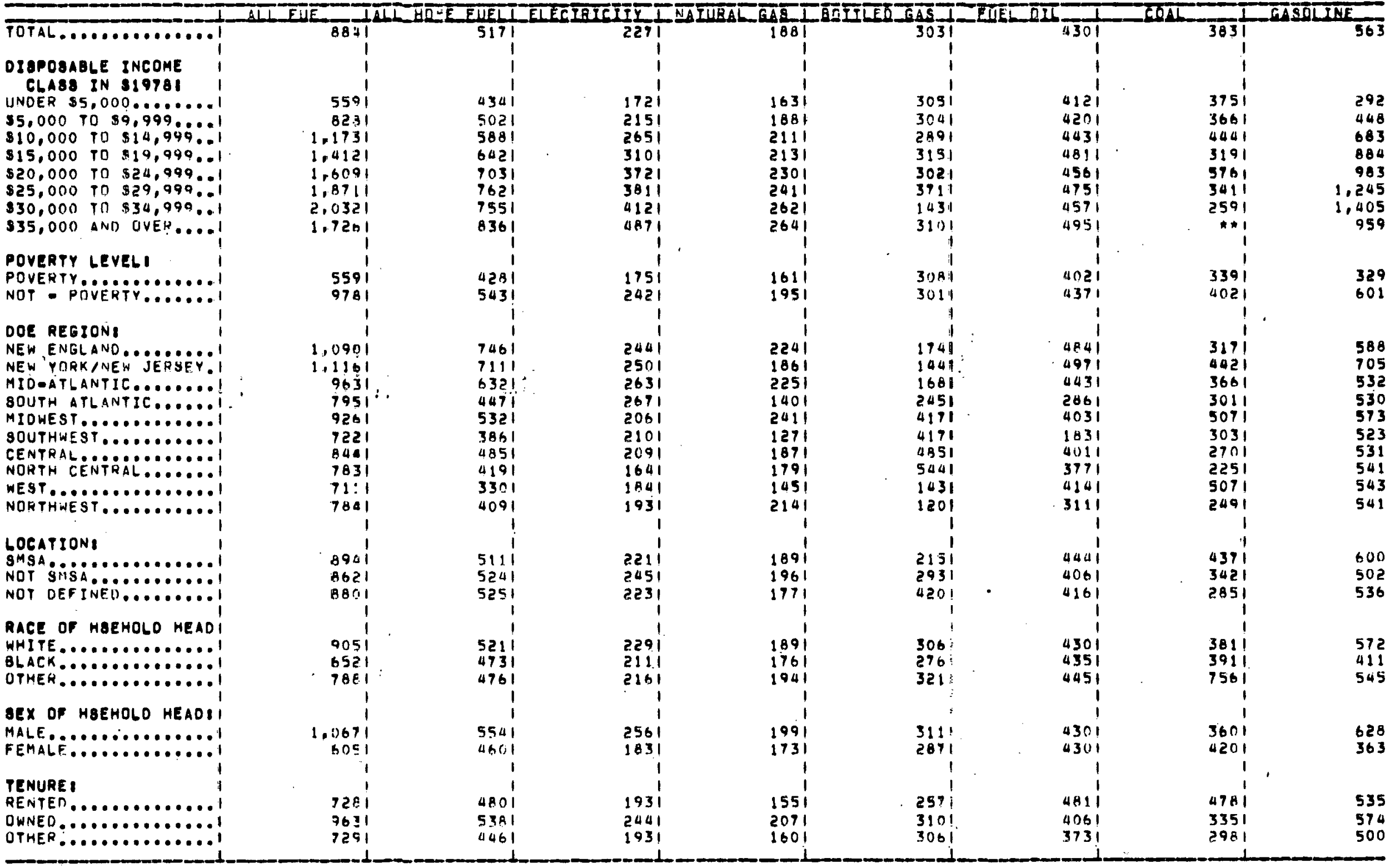

SEE STATISTICAL NOTES 
TABLE A. 13

AVERAGE FUEL EXPENDITURE OF NON-ELOERLY HOUSEHOLDE PURCHASING PARTICULAR FUELSA-19TS (IN I97B SS)

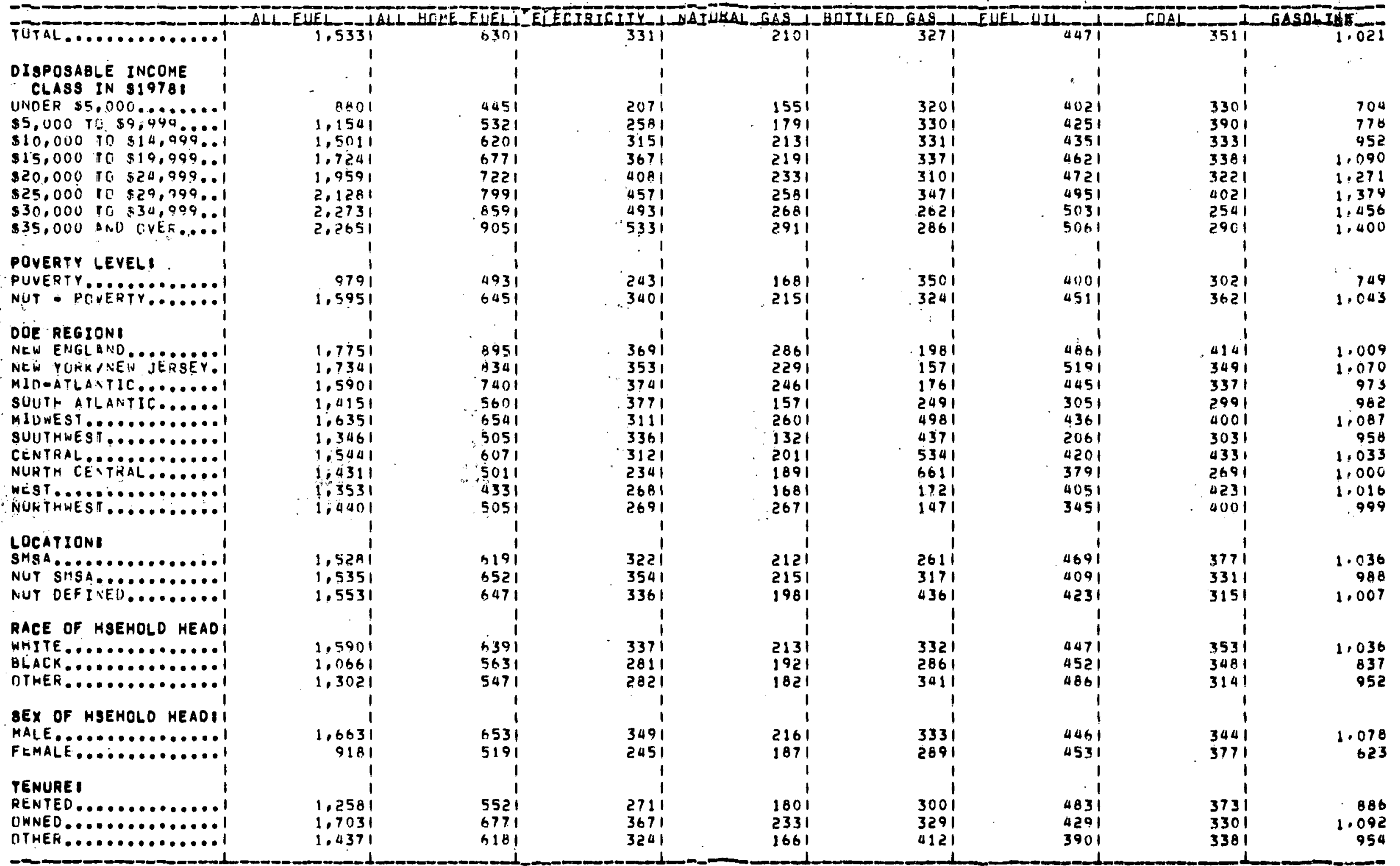

SEE STATISTICAL NOTES 
PER PERSON AVERAGE FUEL EXPENDITJRE OF ALL HOUSEHCLOS PURCHASING PARTICULAR FUELSOA1975 (IN 1978 S8)

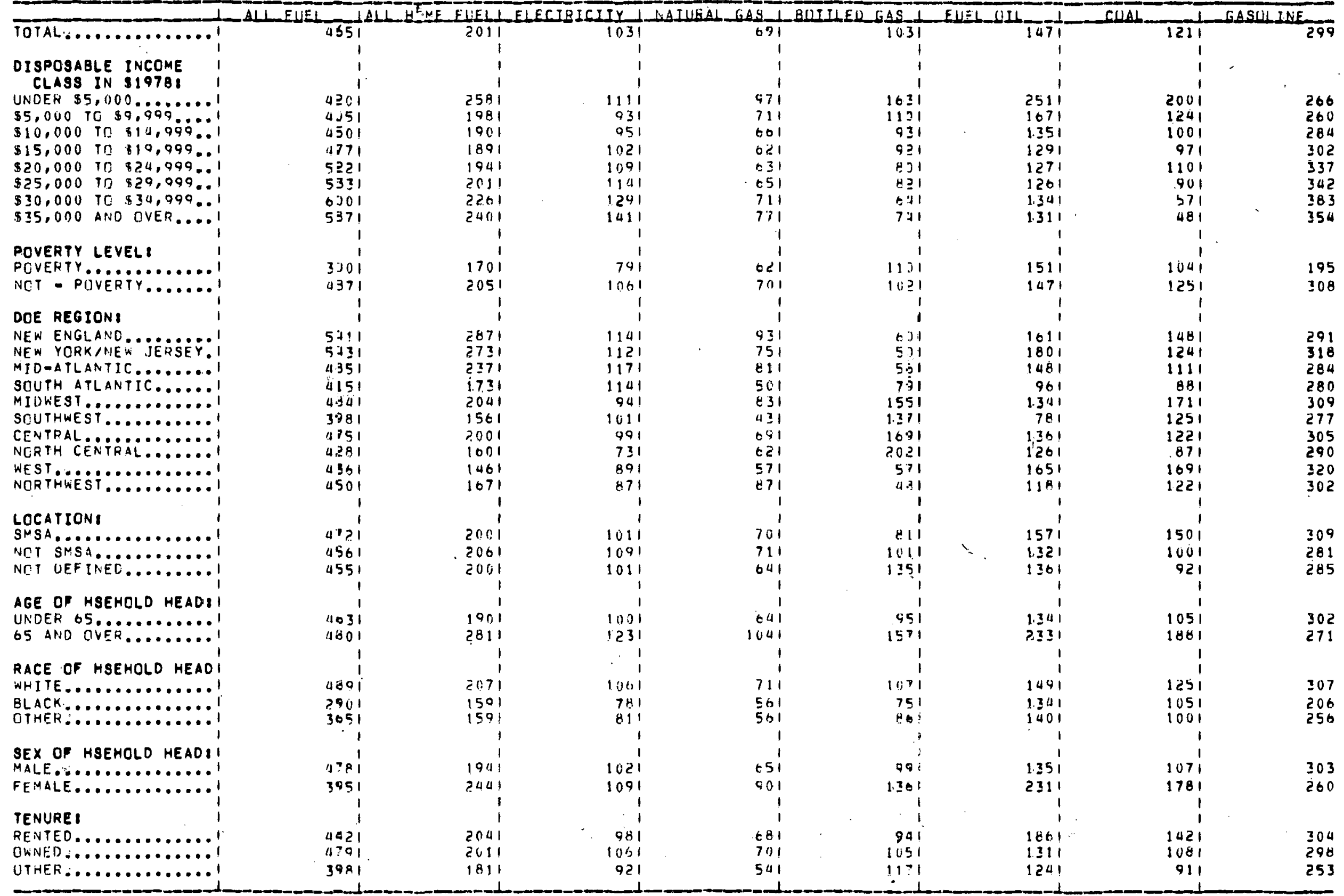

SEE STi TICAL NOTES 


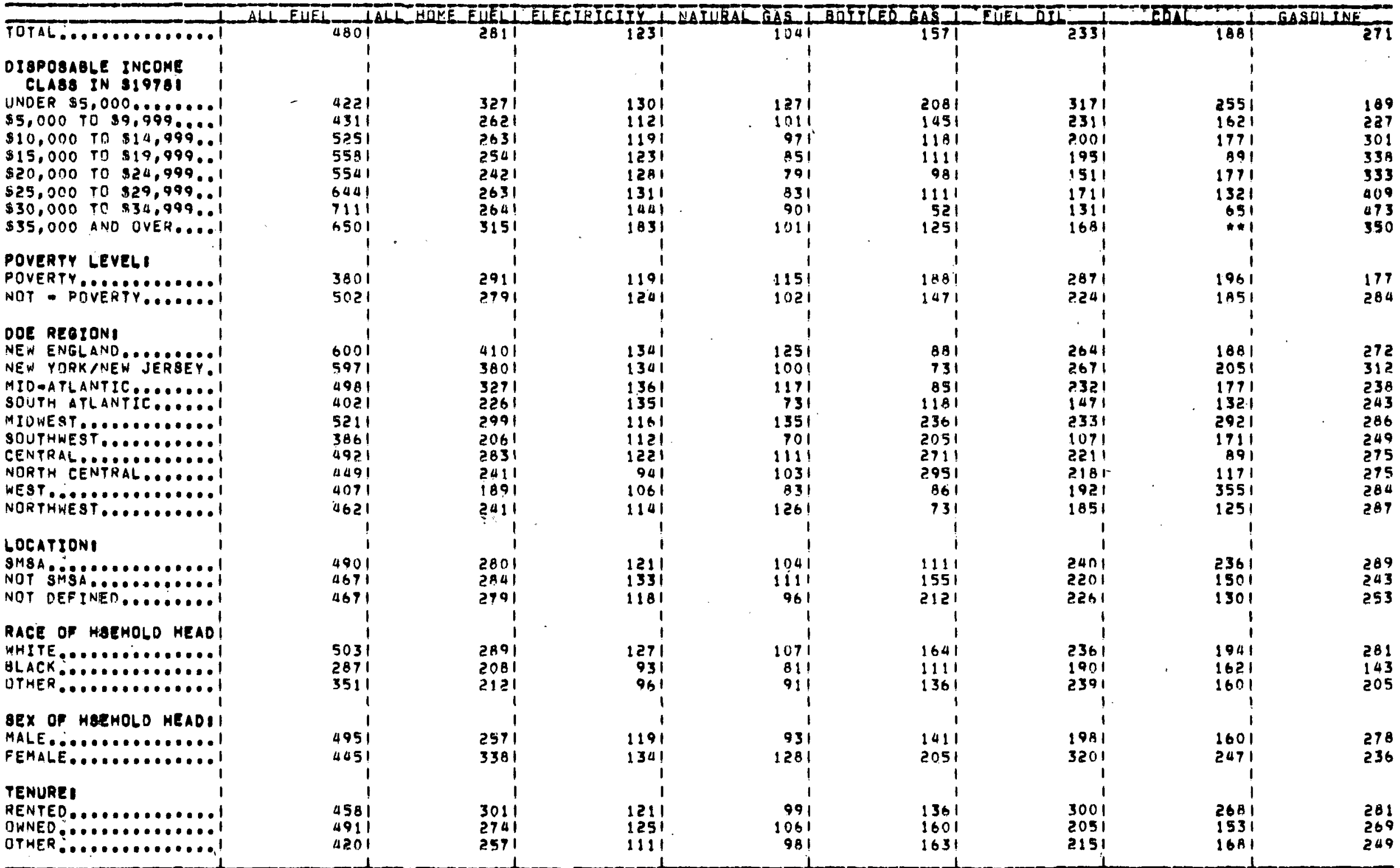

SEE STATISTICAL NOTES 


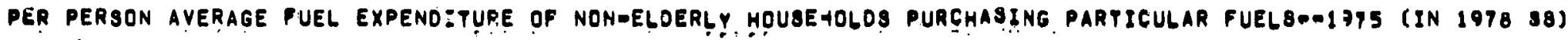

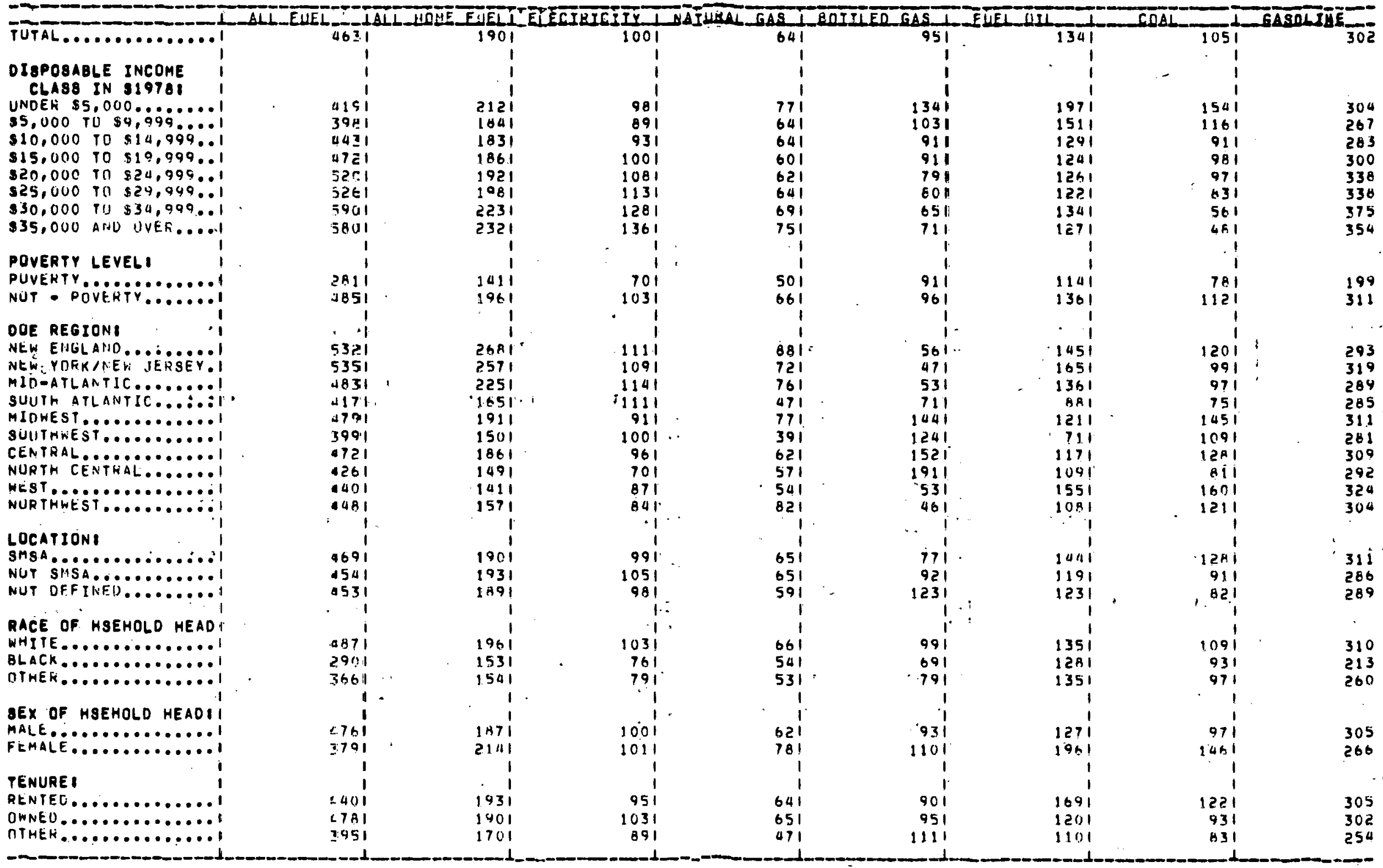

SEE STATISTICAL NOTES 
AVERAGE UISPOSABLE INCEME OF ALL HOUSEHOLOE PURCHASING PARTICULAR FUELSE-197.5 (IN 1978 S8)

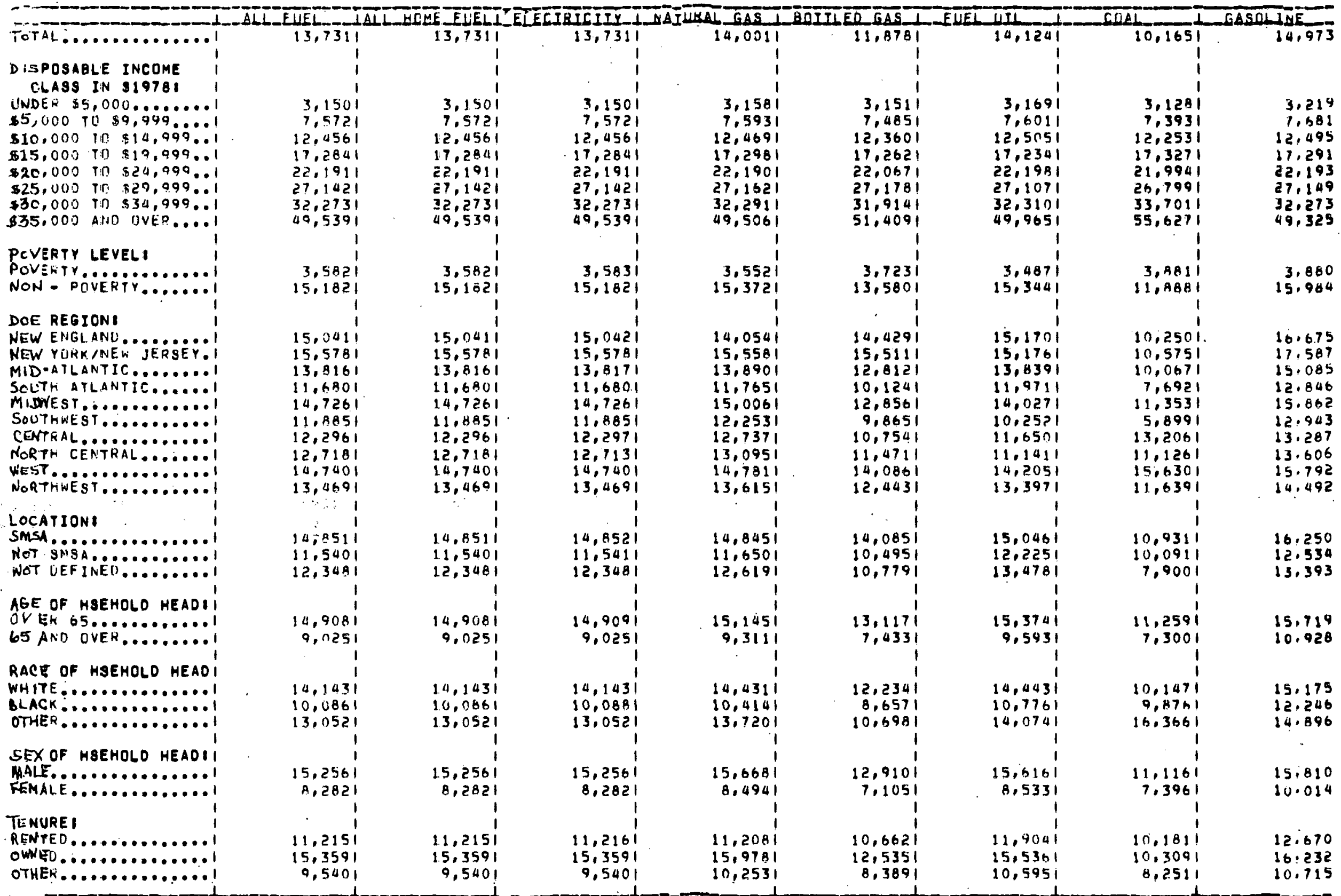

SEE STATISTICAL NOTES 
TABLE A. 18

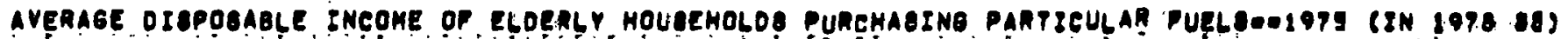

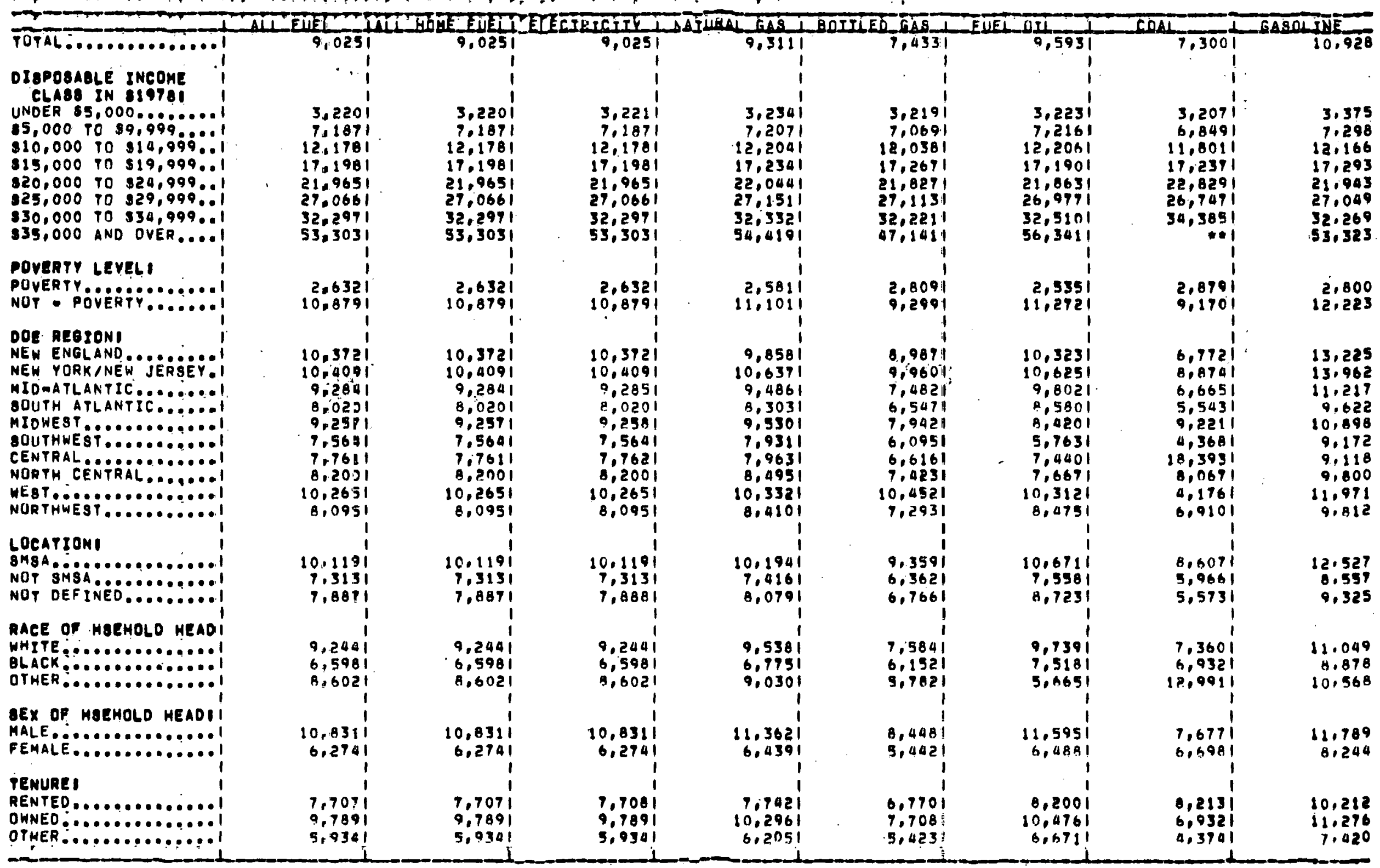

SEE STATISTICAL, NOTES 
AVERAGE DISPOSABLE INCEME OF NON-ELDERLY HEUSEMOLDB PURCHASING PARTICULAR FUELS-A1975 (IN 1978 SS)

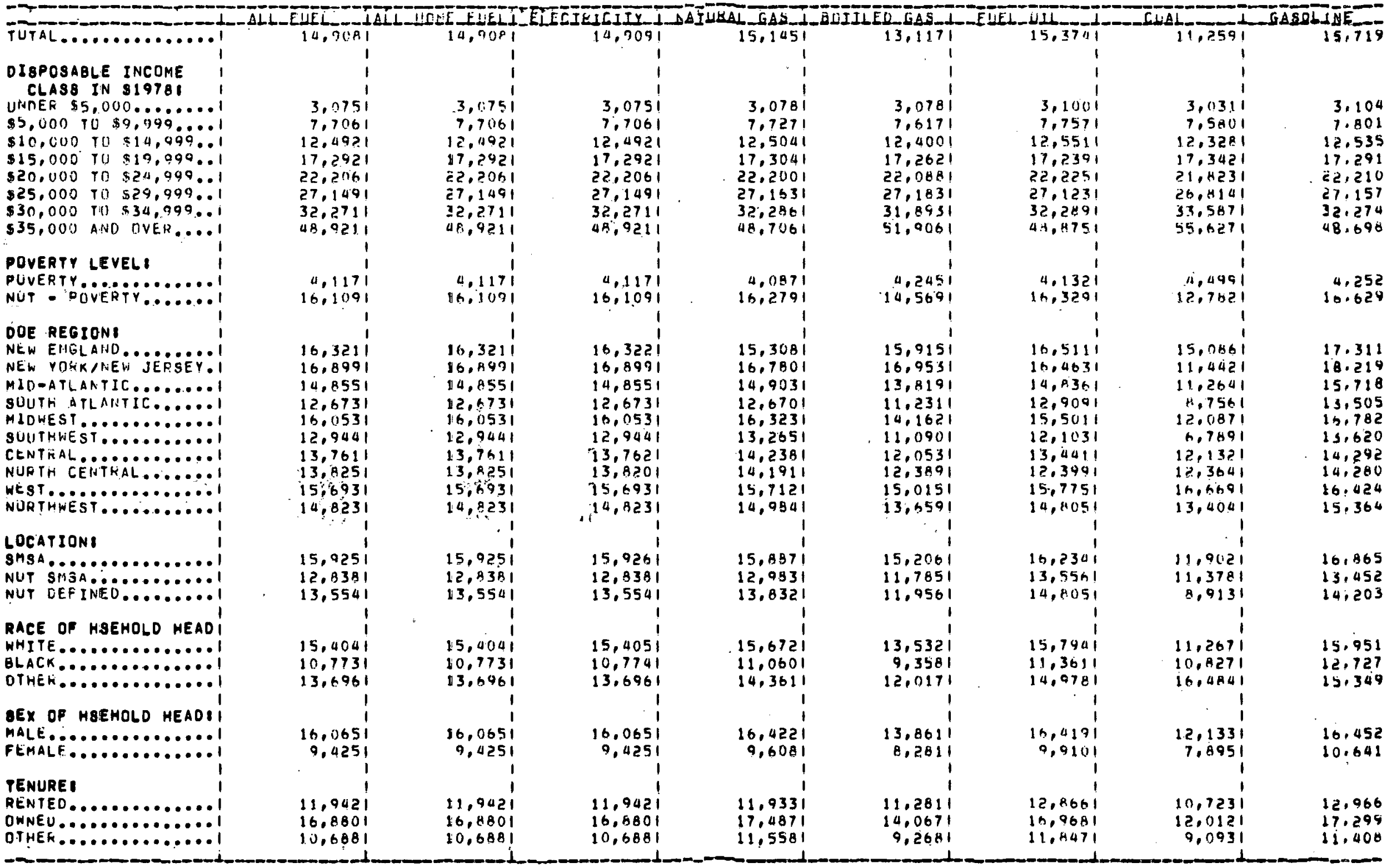

SEE STATISTICAL NOTES 


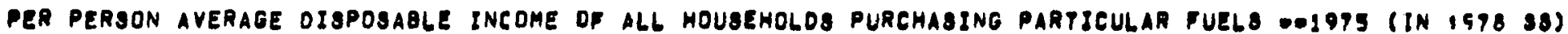

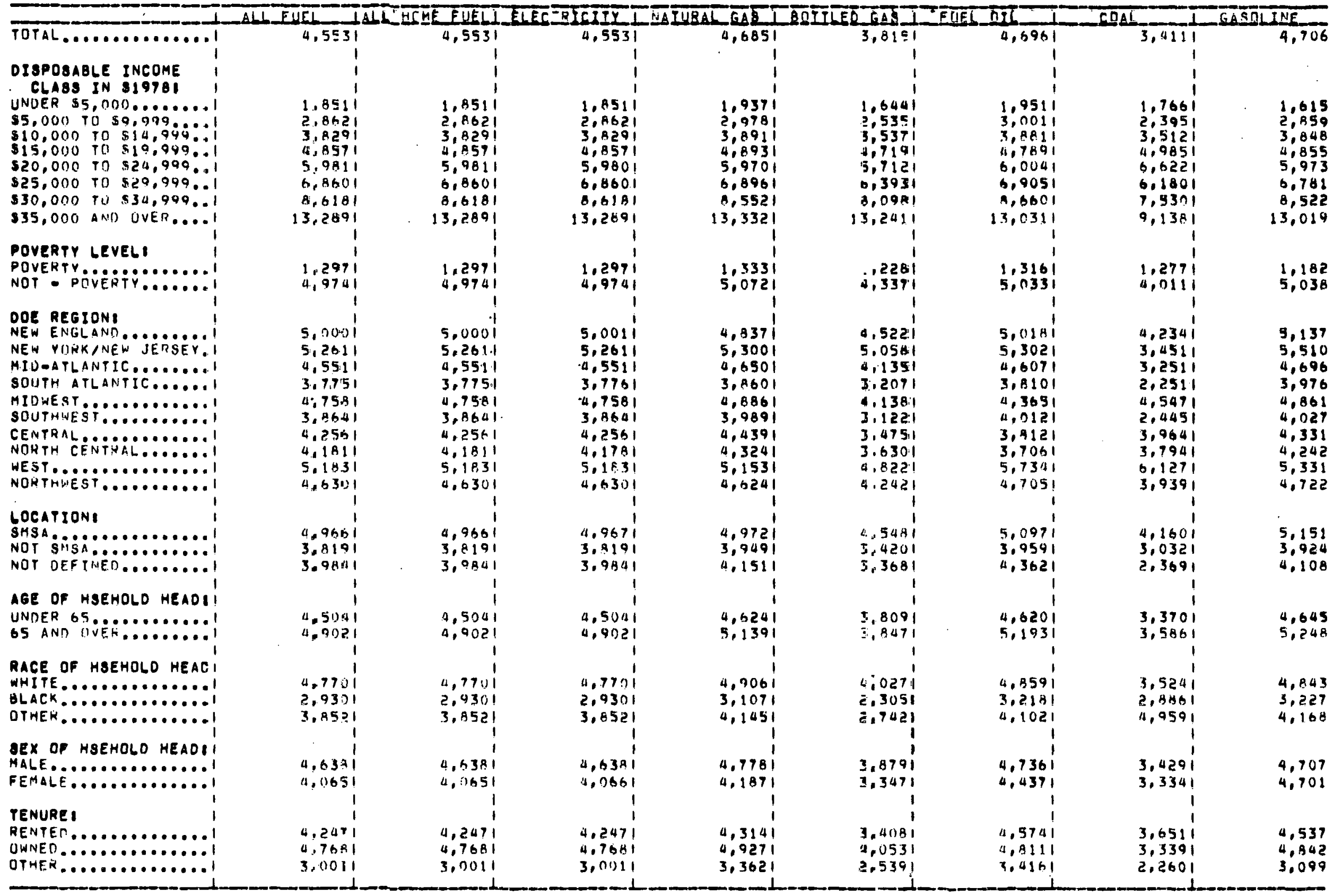


TABLE A. 21

PER PERSON AVERAGE DISPOSABLE INCOYE OF ELDERLY HOUBEHOLOS PURCHASING PARTICULAR FUELS - IQT5 (IN 1978 S8)

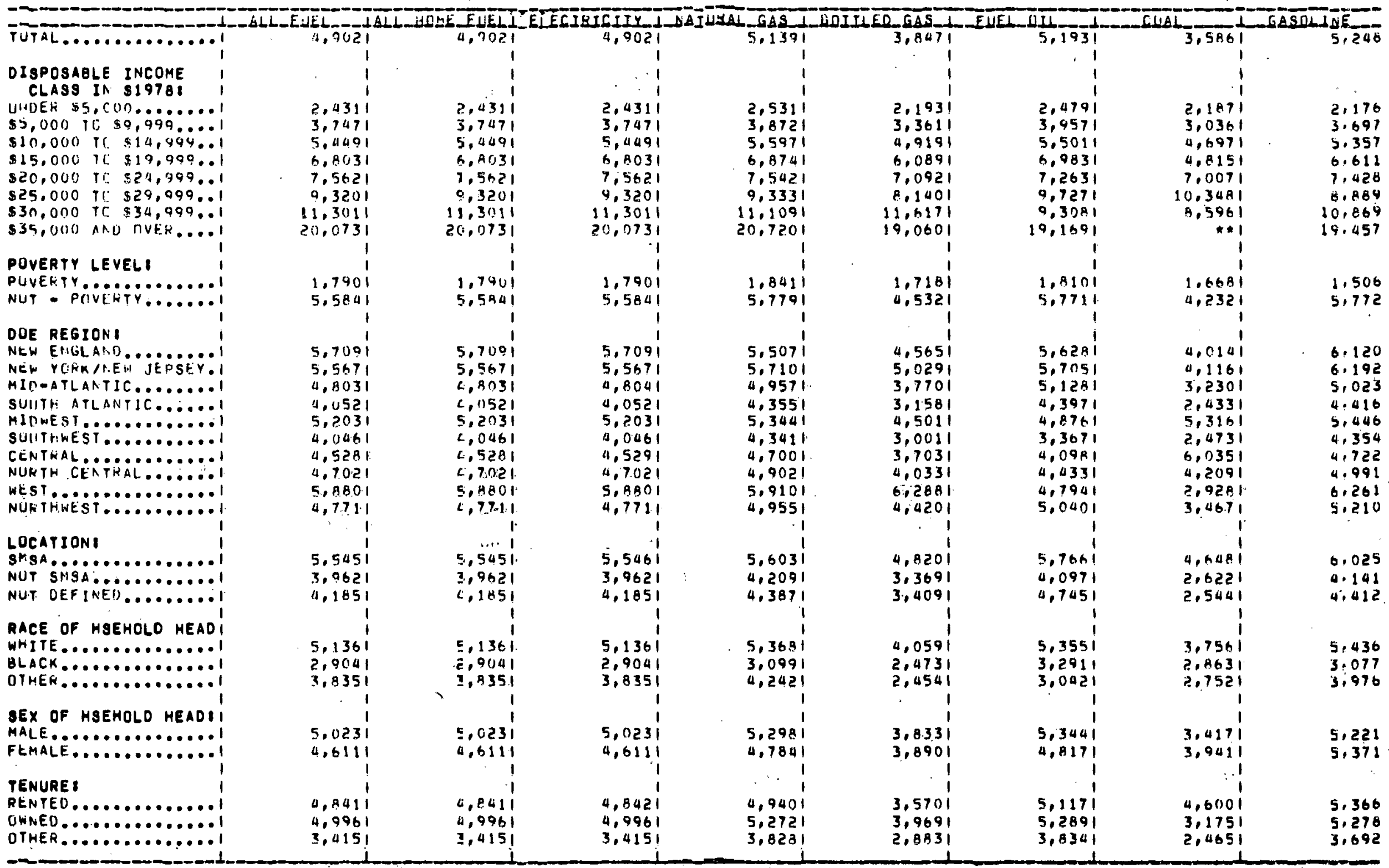

SEE STATISTICAL NOTES 


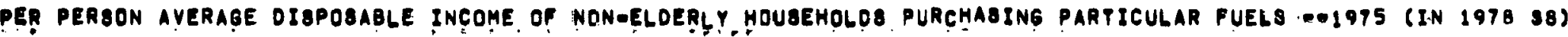

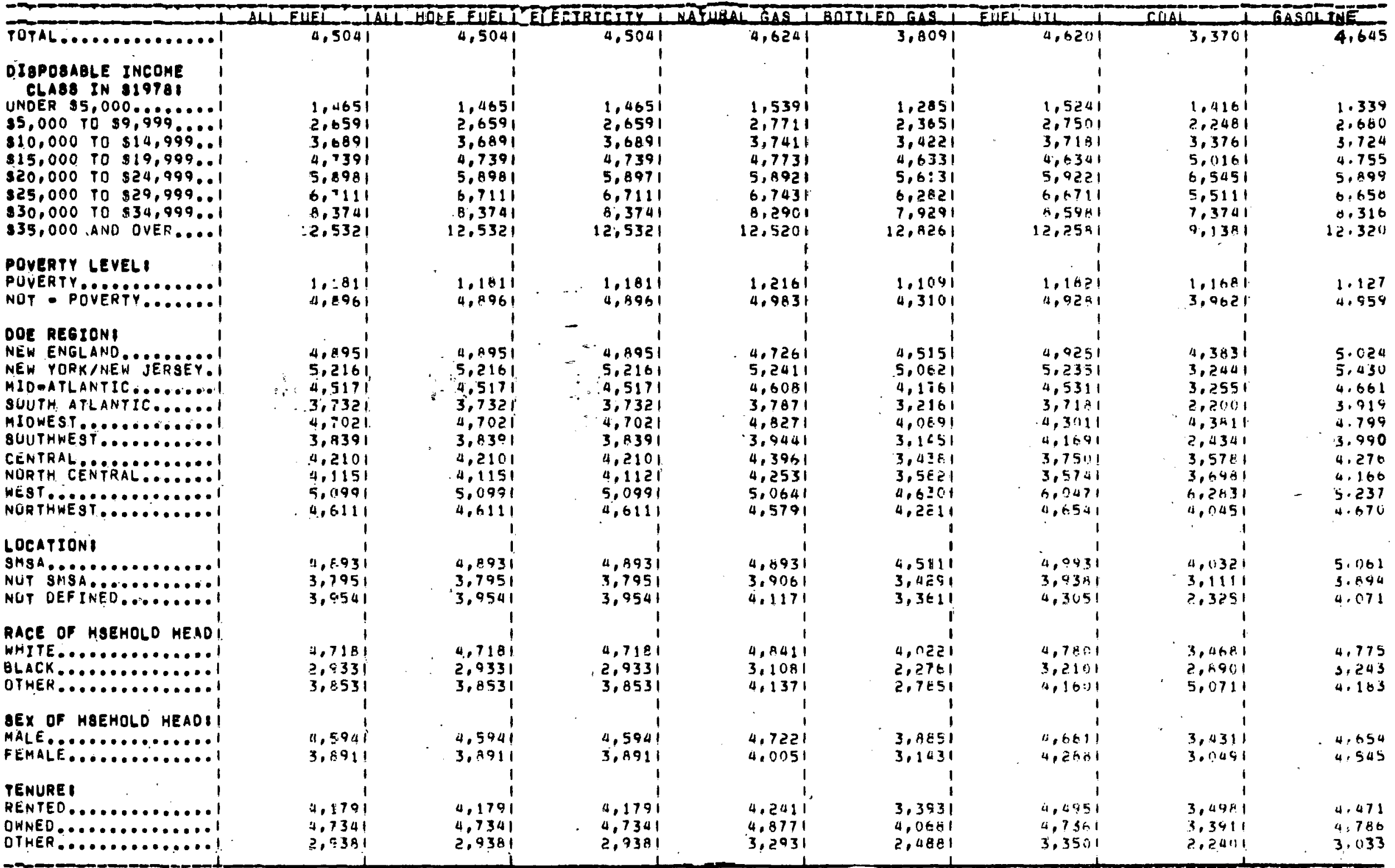

SEE STATISTICAL NOTES 
TABLE A. 23

AYERAGE FUEL EXPENDITURE OF ALL HOUBEHOLDA $A$ A A PERCENT OF DIBPOBABLE INCOMEOOI9TS

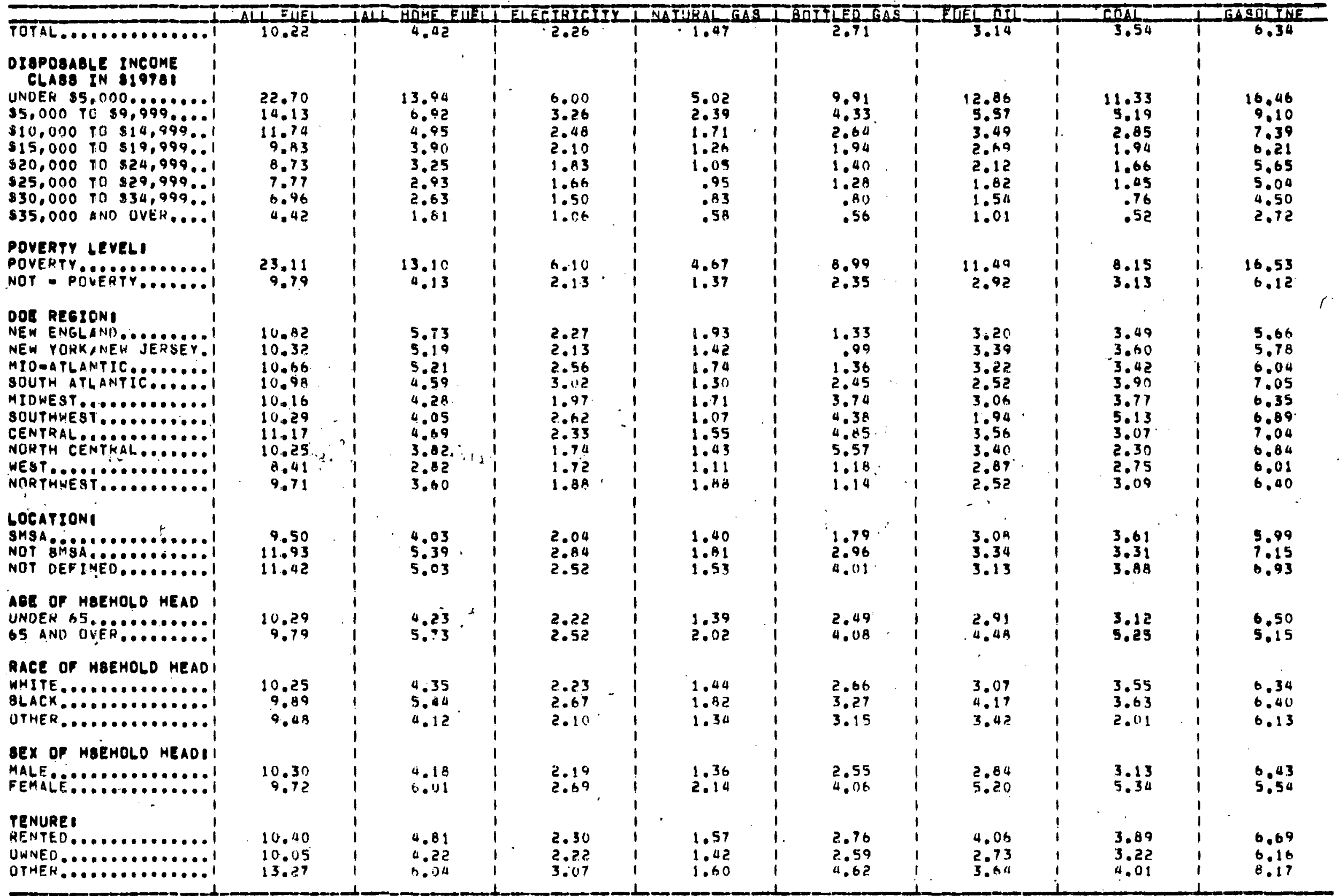

SEE STATISTICAL NOTES 
AYERAGE FUEL EXPENDITURE OF ELDERLY HOUSEHOLDS AS A PERCENT OF OISPUSABLE INCOMEM-IOTS

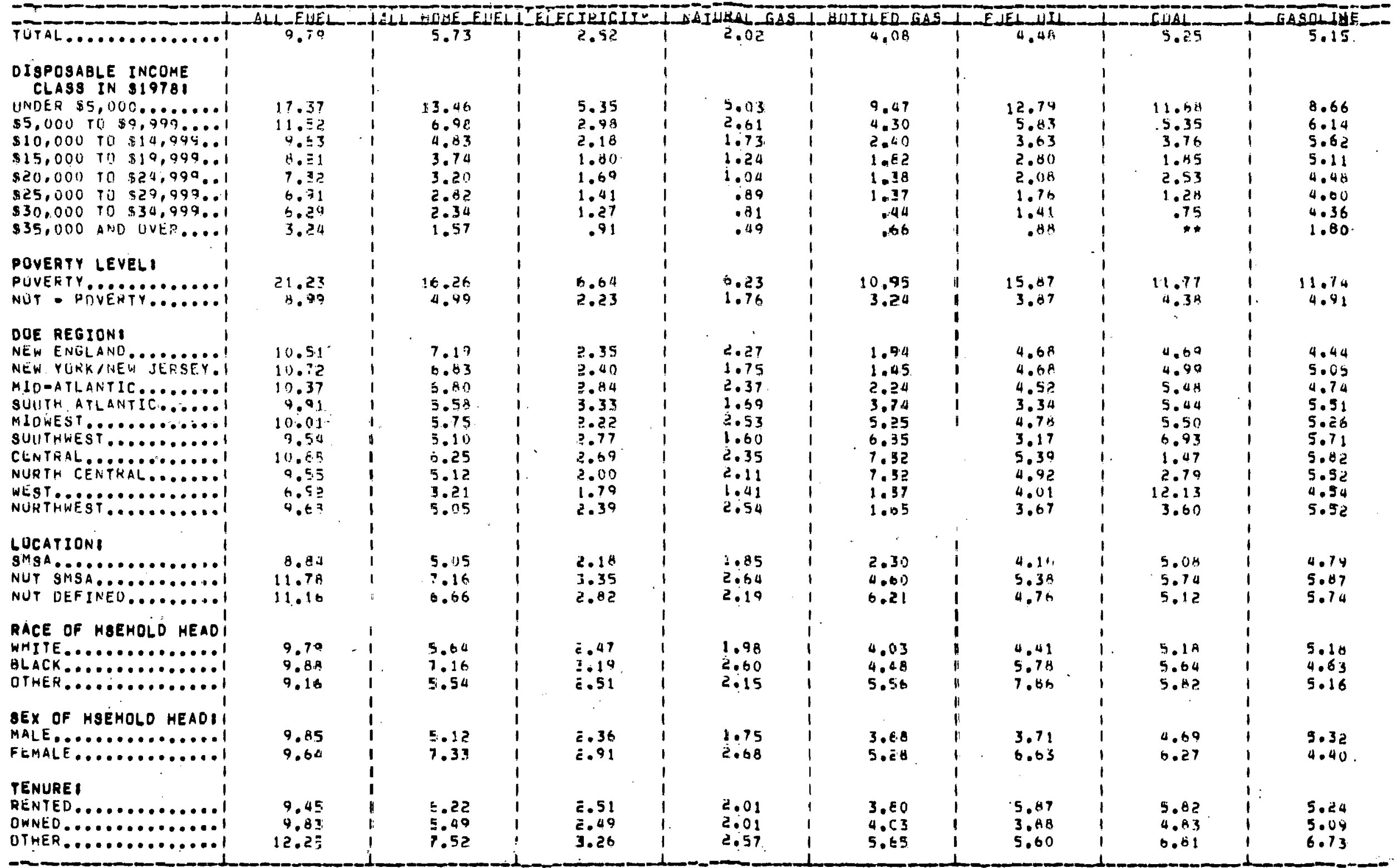

SEE STATISTICAL NOTES 
AVERAGE FUEL EXPENDITURE OF NONEELDERLY HOUSEHOLDS AS A PERCENT OF DISPOSABLE INCOME-OI97S

\begin{tabular}{|c|c|c|c|c|c|c|c|c|c|c|c|c|c|c|c|}
\hline & ALL_EUEL & - & HOLE_E & LUEL__E & ELESIEISIIY. & - NAI & IUSAL_GA & S_L_ & DUDILED_GAS. & $-\alpha$ & 年 & -1 & Cgal & 1. & GASOLIME \\
\hline TUTAL_............. & 10.29 & 1 & 4.23 & 1 & 2.22 & 1 & 1.33 & 1 & 2.49 & $!$ & 2.41 & 1 & 3.12 & 1 & 6.50 \\
\hline 1 & 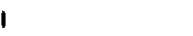 & 1 & & 1 & & 1 & & 1 & & 1 & & 1 & & 1 & 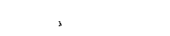 \\
\hline DISPOSABLE INCOME & 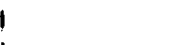 & 1 & & 1 & & 1 & & 1 & & 1 & & 1 & & 1 & \\
\hline CLAS8 IN 51978 I & 1 & 1 & & 1 & & 1 & & 1 & & 1 & & 1 & & 1 & \\
\hline UINDER $\$ 5,000 \ldots \ldots \ldots 1$ & 28.60 & 1 & 14.46 & 1 & 6.72 & 1 & 5.02 & 1 & 10.40 & 1 & 18.95 & 1 & 10.04 & 1 & 25,04 \\
\hline$\$ 5,000$ To $59,999 \ldots \ldots 1$ & 14.98 & $!$ & 0.90 & 1 & 3.35 & 1 & 2.32 & 1 & 4.33 & 1 & 5.47 & 1 & 5.14 & 1 & $y .97$ \\
\hline$\$ 10,000$ in $\$ 14,999 \ldots !$ & 12.01 & $i$ & 4.97 & 1 & 2.52 & 1 & 1.71 & 1 & 2.67 & $!$ & 3.47 & 1 & 2.711 & 1 & 7.00 \\
\hline$\$ 15,000$ TO $\$ 19,999 \ldots 1$ & 9.97 & 1 & 3.91 & 1 & 2.12 & 1 & 1.27 & 1 & 1.96 & $i$ & $2.0 i$ & $\mathbf{i}$ & 1.95 & 1 & $6.3 v$ \\
\hline$\$ 20,000$ T0 $\$ 24,999 . .1$ & 8.82 & 1 & 3.25 & 1 & 1.54 & 1 & 1.05 & 1 & 1.40 & $!$ & 2.12 & 1 & 1.98 & 1 & 3.72 \\
\hline$\$ 25,000$ T0 $\$ 29,999 \ldots 1$ & 7.84 & 1 & 2.94 & 1 & $1 \cdot 5$ & 1 & .95 & 1 & 1.28 & 1 & 1.43 & 1 & 1.31 & 1 & 5.0 .4 \\
\hline$\$ 30,000$ T0 \$34,999..1 & 7.04 & 1 & 2.66 & 1 & 1.53 & 1 & .83 & 1 & .82 & 1 & $1.5 h$ & 1 &. .76 & 1 & +.51 \\
\hline$\$ 35.000$ AND OVER....। & 4.63 & $!$ & 1.85 & 1 & 1.09 & 1 & .60 & 1 & .55 & 1 & 1.113 & 1 & $.5 ?$ & 1 & 2.03 \\
\hline & & 1 & & 1 & & 1 & & 1 & & 1 & & 1 & & 1 & \\
\hline POVERTY LEVELI & 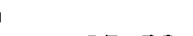 & 1 & & 1 & & 1 & & 1 & & $!$ & & 1 & & 1 & \\
\hline PUVERTY ............। & 23.79 & $!$ & 11.96 & 1 & 5.91 & 1 & $4.1 ?$ & 1 & 6.25 & 1 & 9.67 & 1 & $6.7 ?$ & 1 & 17.62 \\
\hline NUT - POVERTY........ I & 9.90 & 1 & 4.01 & 1 & 2.11 & 1 & 1.32 & 1 & 2.22 & 1 & $2.7 \%$ & 1 & 2.63 & 1 & 0.27 \\
\hline 1 & & 1 & & 1 & & 1 & & 1 & & 1 & & 1 & & 1 & \\
\hline DOE REGIONI & 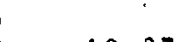 & 1 & & $!$ & & 1 & & 1 & & 1 & & 1 & & 1 & \\
\hline NLW ENGLAND $\ldots \ldots, \ldots !$ & 10.87 & 1 & 5.48 & $i$ & 2.26 & 1 & 1.87 & 1 & 1.24 & 1 & 2.45 & 1 & 2.75 & 1 & 5.83 \\
\hline NEW YORK/NEW JERSEY.I & 10.26 & $\mathbf{I}$ & 4.94 & 1 & 2.09 & 1 & 1.37 & 1 & .93 & 1 & 3.15 & 1 & 3.05 & 1 & $\$ .87$ \\
\hline MIDAATLGNYIC .......! & 10.70 & 1 & $4.9 B$ & 1 & 2.52 & 1 & 1.65 & 1 & 1.27 & 1 & 3.00 & 1 & 2.49 & 1 & 0.18 \\
\hline SUUTh ATLANTIC...... & 11.17 & 1 & 4.42 & 1 & 2.97 & 1 & 1.24 & 1 & 2.22 & 1 & 2.37 & 1 & 3.4 ? & $!$ & 7.27 \\
\hline MIDWEST _.......... & 10.18 & 1 & 9.07 & 1 & 1.94 & 1 & 1.59 & 1 & 3.51 & 1 & 2.31 & 1 & 3.31 & $i$ & 0.48 \\
\hline SOUTHWEST.......... & 10.40 & 1 & 3.90 & 1 & 2.59 & 1 & 1.00 & 1 & 3.94 & 1 & 1.70 & 1 & $4.4 n$ & 1 & 1.03 \\
\hline CENTRAL_........! & $1: 1 \cdot 22$ & 1 & .4 .41 & 1 & 2.27 & 1 & 1.41 & 1 & 0.43 & 1 & 3.12 & 1 & 3.57 & 1 & 7.23 \\
\hline NURTH CENTRAL_...... & 10.35 & 1 & 3,63 & 1 & 1.70 & 1 & 1.33 & 1 & 5.33 & 1 & 3.06 & 1 & $? \cdot 1, x^{2}$ & 1 & 1.00 \\
\hline WEST_............। & 8.62 & 1 & 2.76 & 1 & 1.71 & 1 & 1.07 & 1 & 1.14 & 1 & 2.57 & $!$ & 2.54 & 1 & 6.19 \\
\hline NURTHWEST $\ldots \ldots \ldots \ldots \ldots$. . & 9.72 & 1 & 3.41 & 1 & 1.81 & 1 & 1.78 & 1 & 1.08 & 1 & 2.33 & 1 & 2.94 & 1 & 6.50 \\
\hline 1 & & 1 & & 1 & & 1 & & 1 & & $!$ & & 1 & . & 1 & \\
\hline LOCATIOKI & & i & & 1 & & 1 & & 1 & & 1 & & 1 & & 1 & \\
\hline sMsA. $\ldots \ldots \ldots \ldots \ldots$ & 9.59 & 1 & 3.89 & 1 & 2.02 & 1 & $1 \cdot 34$ & 1 & 1.72 & 1 & 2. 4? & 1 & 3.17 & 1 & 0.14 \\
\hline NUT $8 M 9 A \ldots \ldots \ldots \ldots \ldots l$ & 11.96 & 1 & 5.03 & 1 & 2.75 & 1 & 1.66 & 1 & 2.69 & 1 & 3.112 & 1 & 2. . $\$ 1$ & 1 & 7.34 \\
\hline NOT DEFINEO ......... I & 11.46 & 1 & 4.77 & 1 & 2.46 & 1 & 1.43 & 1 & 3.65 & 1 & 2.96 & 1 & 3.54 & 1 & 7.04 \\
\hline & & 1 & & 1 & & 1 & & 1 & & 1 & & 1 & & 1 & \\
\hline RACE OP HAEHOLD HEADI & & $i$ & & 1 & & 1 & & 1 & & 1 & & 1 & & 1 & \\
\hline WHITE: $\ldots \ldots \ldots \ldots \ldots \ldots$ I & 10.32 & 1 & 4.15 & 1 & 2.19 & 1 & 1.36 & 1 & 2.45 & 1 & 2.93 & 1 & 3.13 & 1 & 6.49 \\
\hline 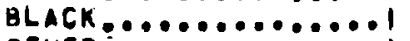 & 9.89 & 1 & 5.23 & 1 & 2.60 & 1 & 1.73 & 1 & 3.05 & 1 & 3.94 & 1 & 3.21 & 1 & 6.37 \\
\hline DTHER $\ldots \ldots \ldots \ldots \cdots \cdots \cdots$ I & 9.50 & 1 & 3.99 & 1 & 2.06 & 1 & 1.27 & 1 & $2 \cdot 34$ & 1 & 3.24 & 1 & 1.41 & 1 & 0.21 \\
\hline & & 1 & & 1 & & 1 & & 1 & & 1 & & 1 & & 1 & \\
\hline SEX OF HAEHOLO HEAOII & & 1 & & $\mathbf{I}$ & & 1 & & 1 & & 1 & & 1 & & 1 & \\
\hline MALE,$\ldots \cdots \cdots \cdots \cdots \cdots$ L & 10.35 & 1 & 4.07 & 1 & 2.17 & 1 & 1.31 & 1 & 2.40 & 1 & 2.72 & 1 & 2.34 & 1 & 6.56 \\
\hline FEMALE $\ldots \ldots \cdots \cdots \cdots \cdots$ । & 9.74 & 1 & 5.51 & $!$ & 2.60 & 1 & 1.94 & 1 & 3.49 & 1 & 4.57 & $\mathbf{i}$ & 4.75 & 1 & 5.85 \\
\hline 1 & & 1 & & 1 & & 1 & & 1 & & 1 & & 1 & & 1 & \\
\hline TENUAE I & & 1 & & 1 & & 1 & & 1 & & 1 & & 1 & & 1 & \\
\hline RENTED $\ldots \ldots \ldots \ldots \ldots \ldots$ I & 10.53 & 1 & 4.62 & 1. & 2.27 & 1 & 1.51 & $i$ & 2.66 & 1 & 3.70 & 1 & 3.48 & 1 & 6.83 \\
\hline OWNEO $\ldots \ldots \ldots \ldots \ldots \ldots$ I & 10.09 & 1 & 4.01 & 1 & 2.17 & 1 & 1.33 & 1 & 2.34 & $!$ & 2.53 & 1 & 2.75 & 1 & 6.31 \\
\hline QTHER_........... I & 13.44 & $!$ & 5.78 & 1 & 3.03 & 1 & 1.43 & 1 & 4.44 & 1 & $3 . ? 4$ & $!$ & 3.72 & 1 & 8.36 \\
\hline
\end{tabular}

SEE STATISTICAL NOTES 


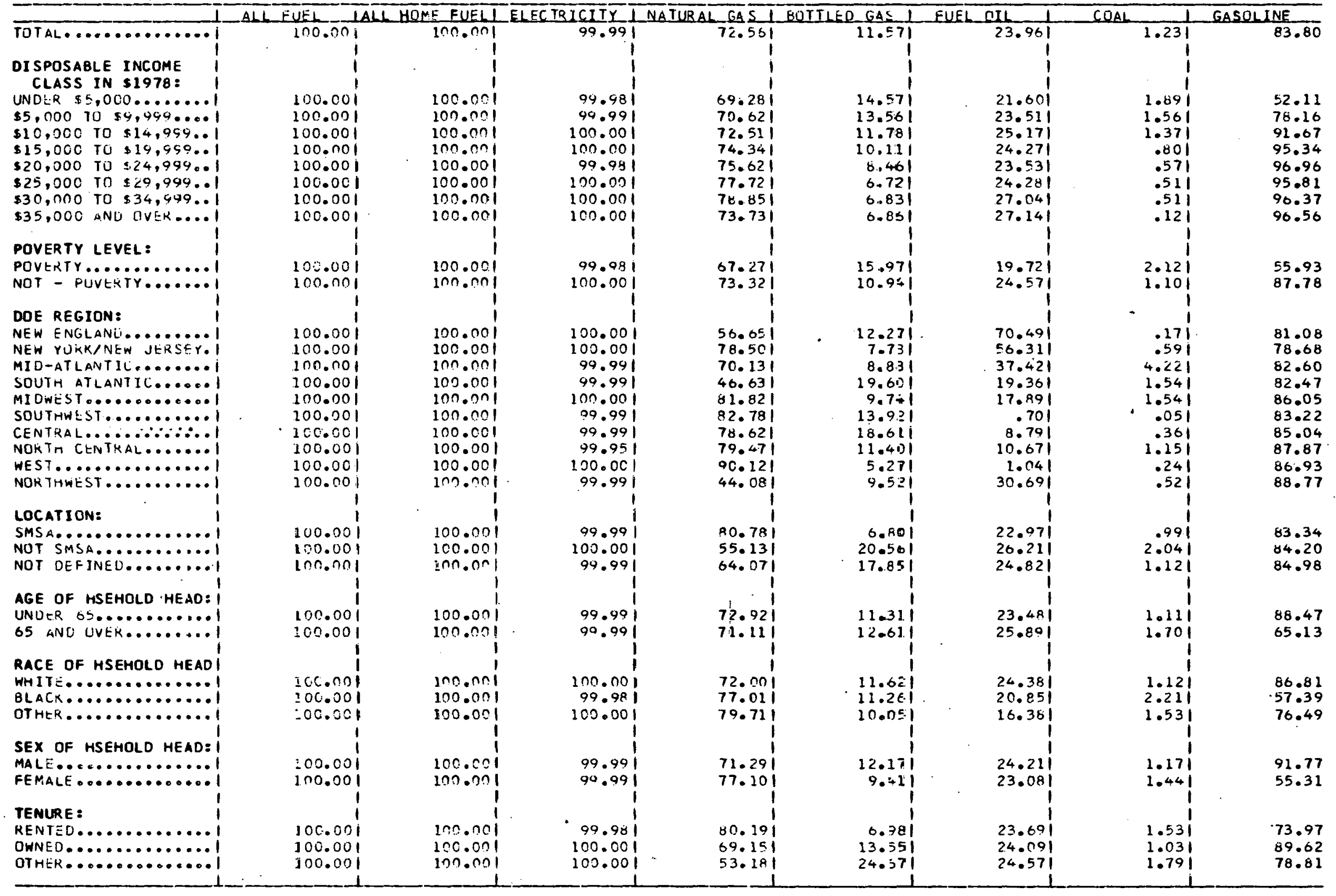




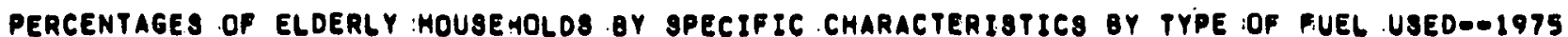

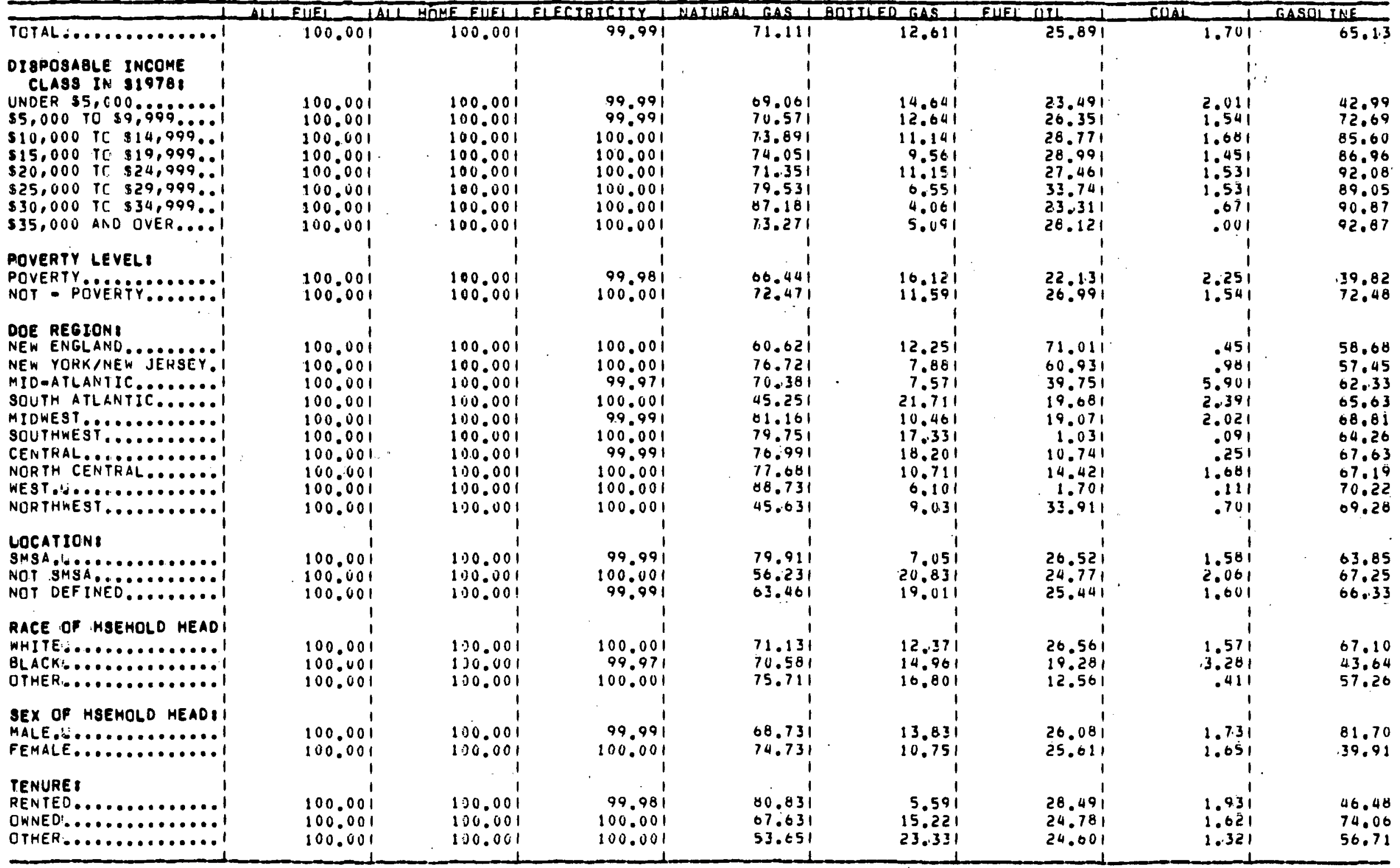

SEE STATISTICAL NOTES 


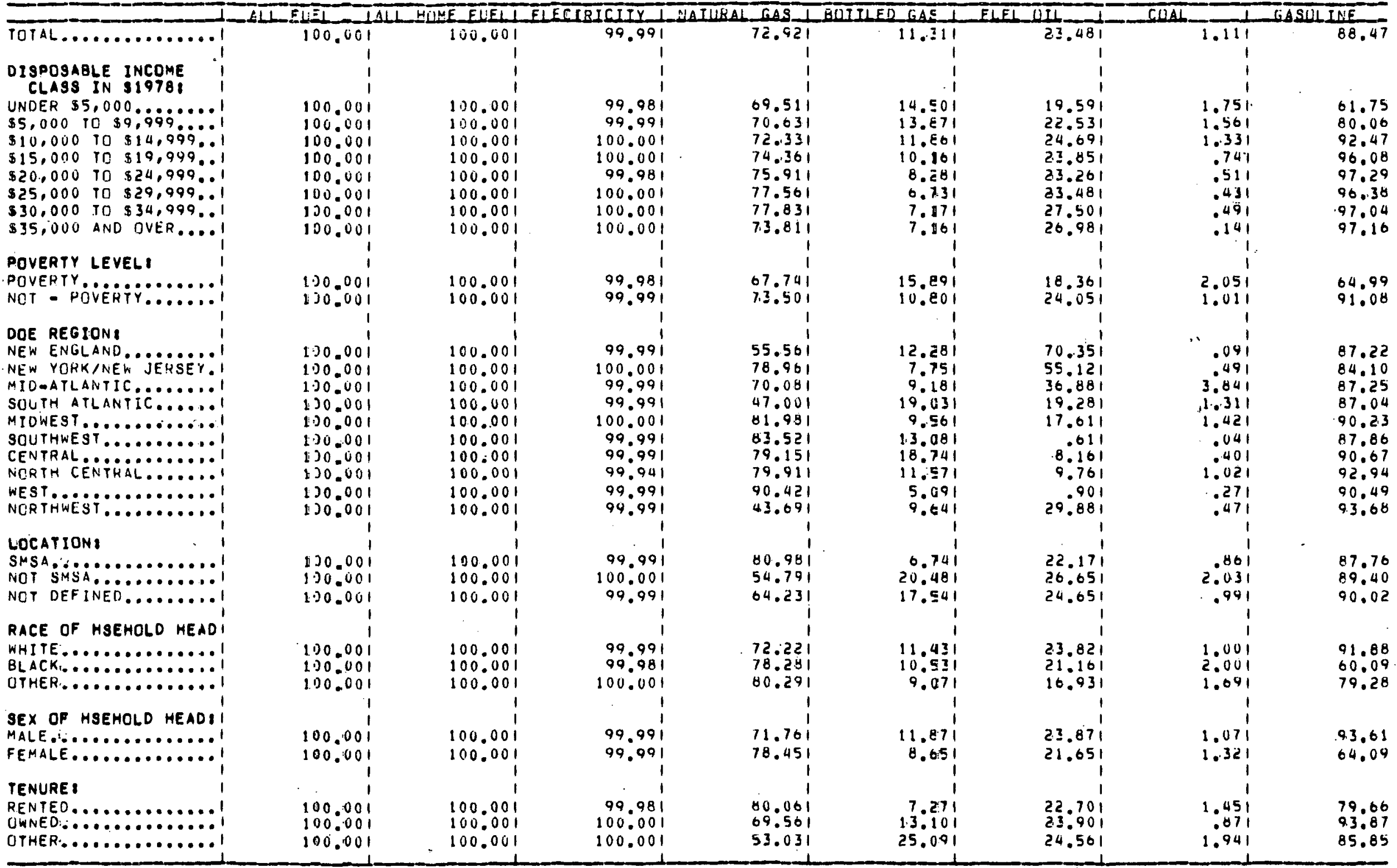

SEE STATISTICAL NOTES 


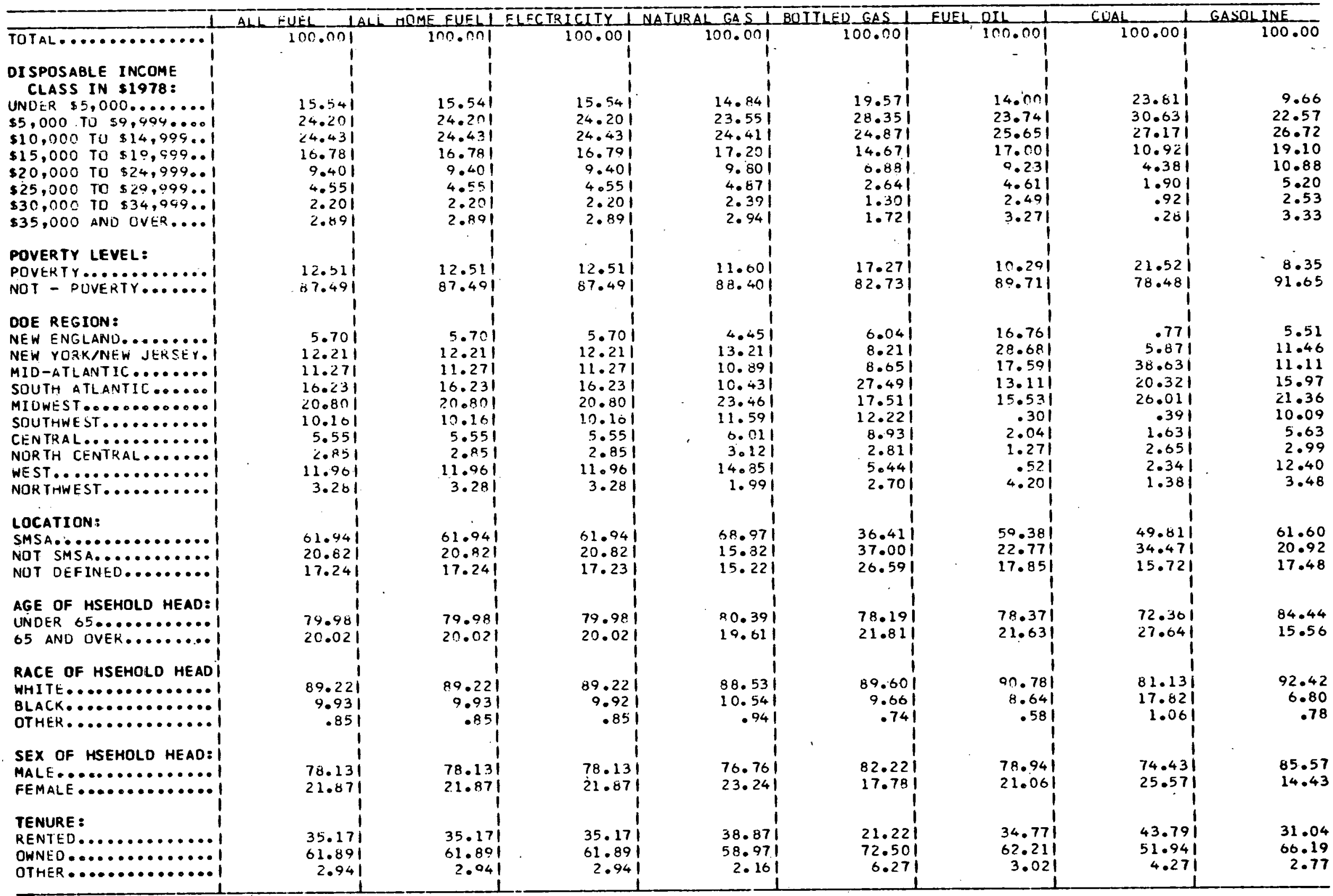

SEI STATISTICAL NOTES 


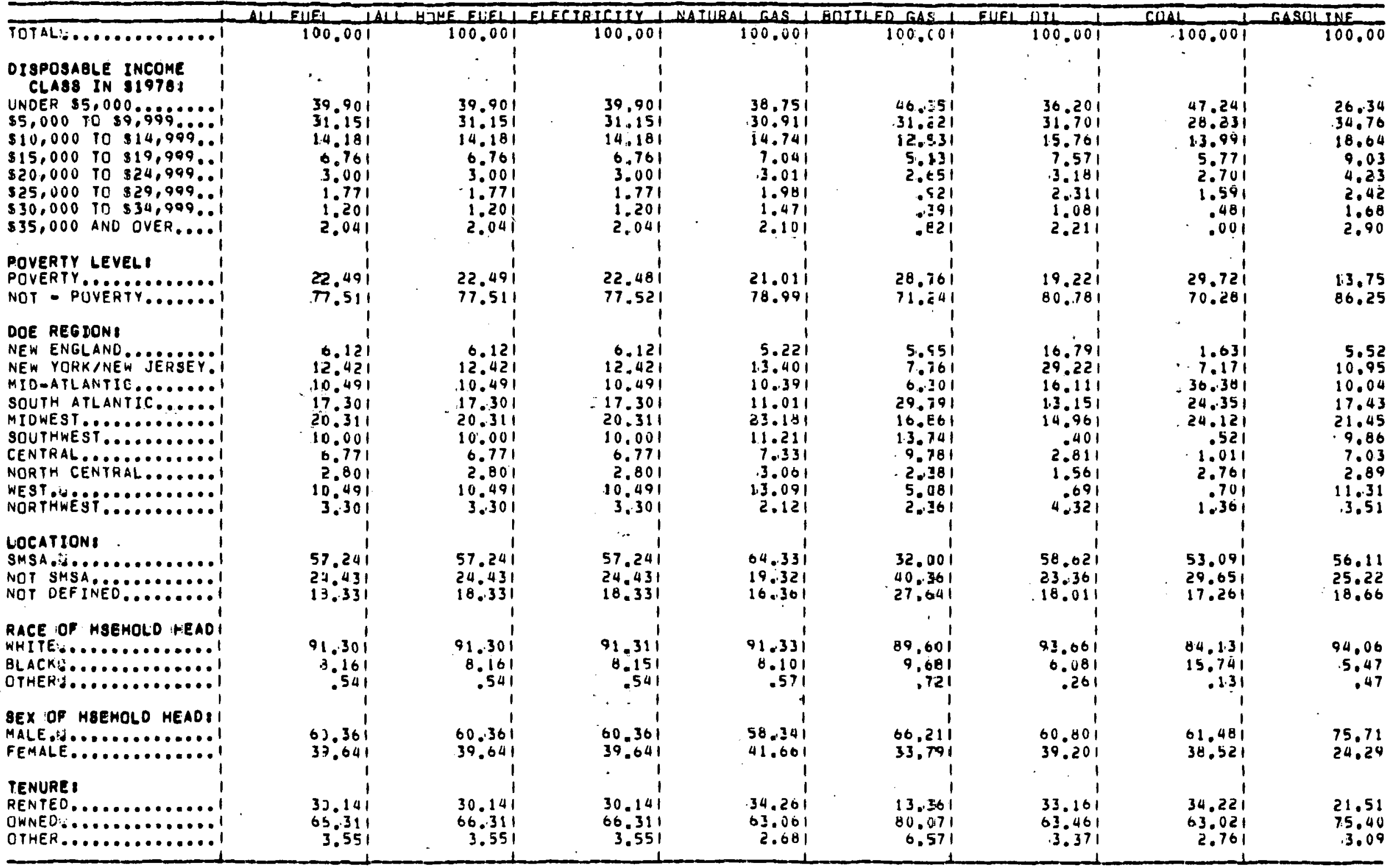


PERCENTAGES OF NON-ELDERLY HOUSEHOLOS BY SPECIFIC FUELS USED BY CHARACTERJSTIC-O1975

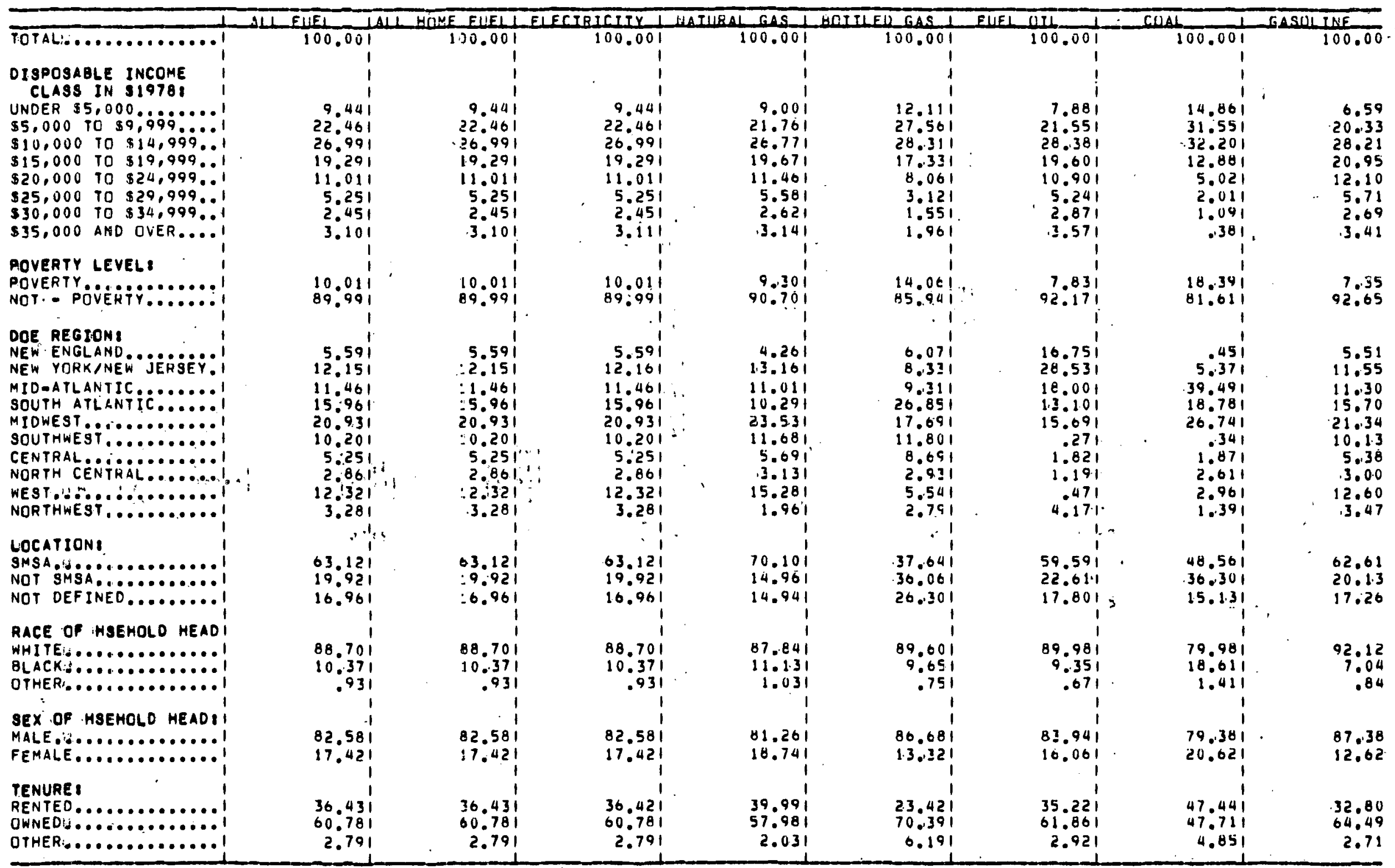

SEE STATISTICAL NOTES 


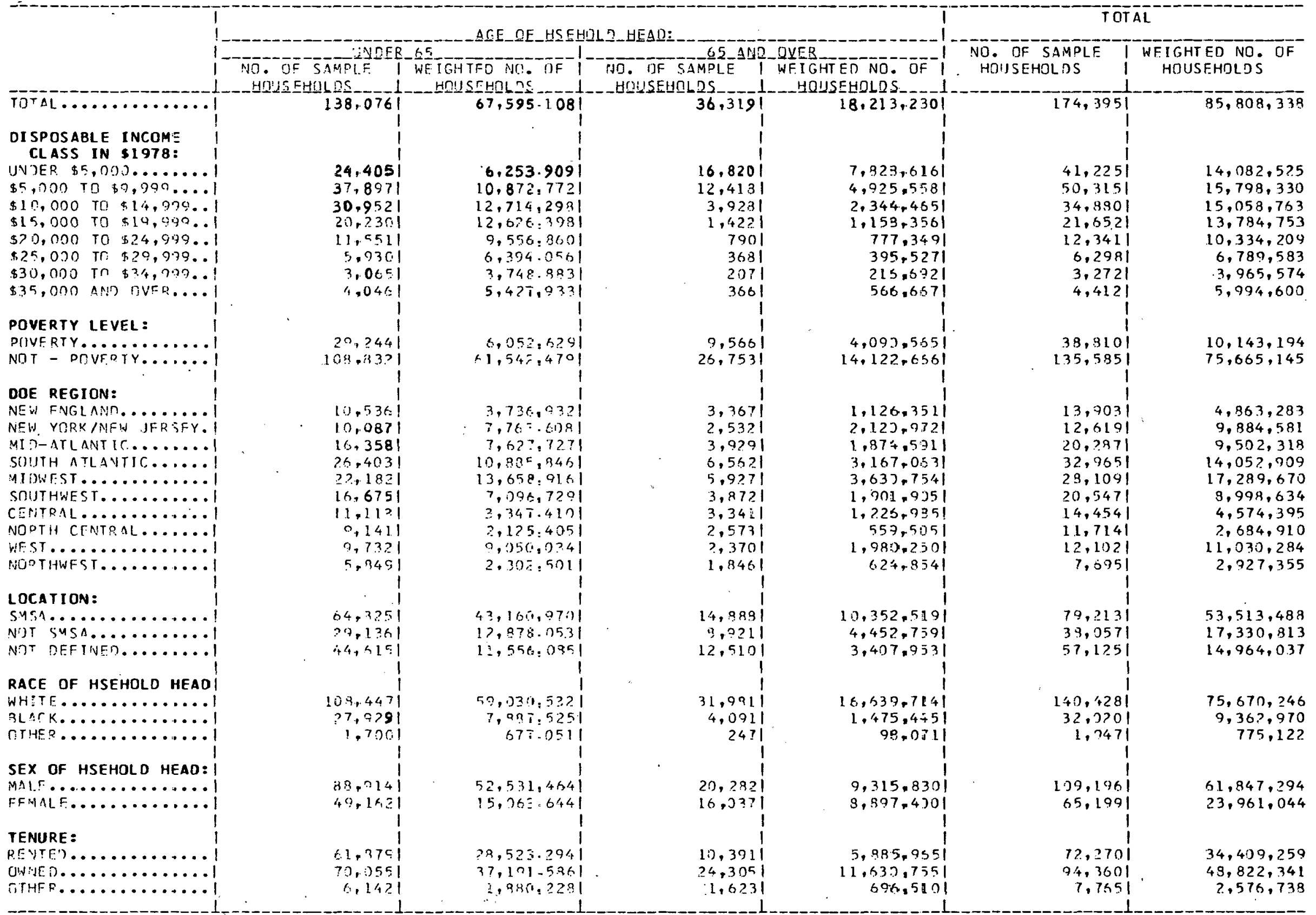




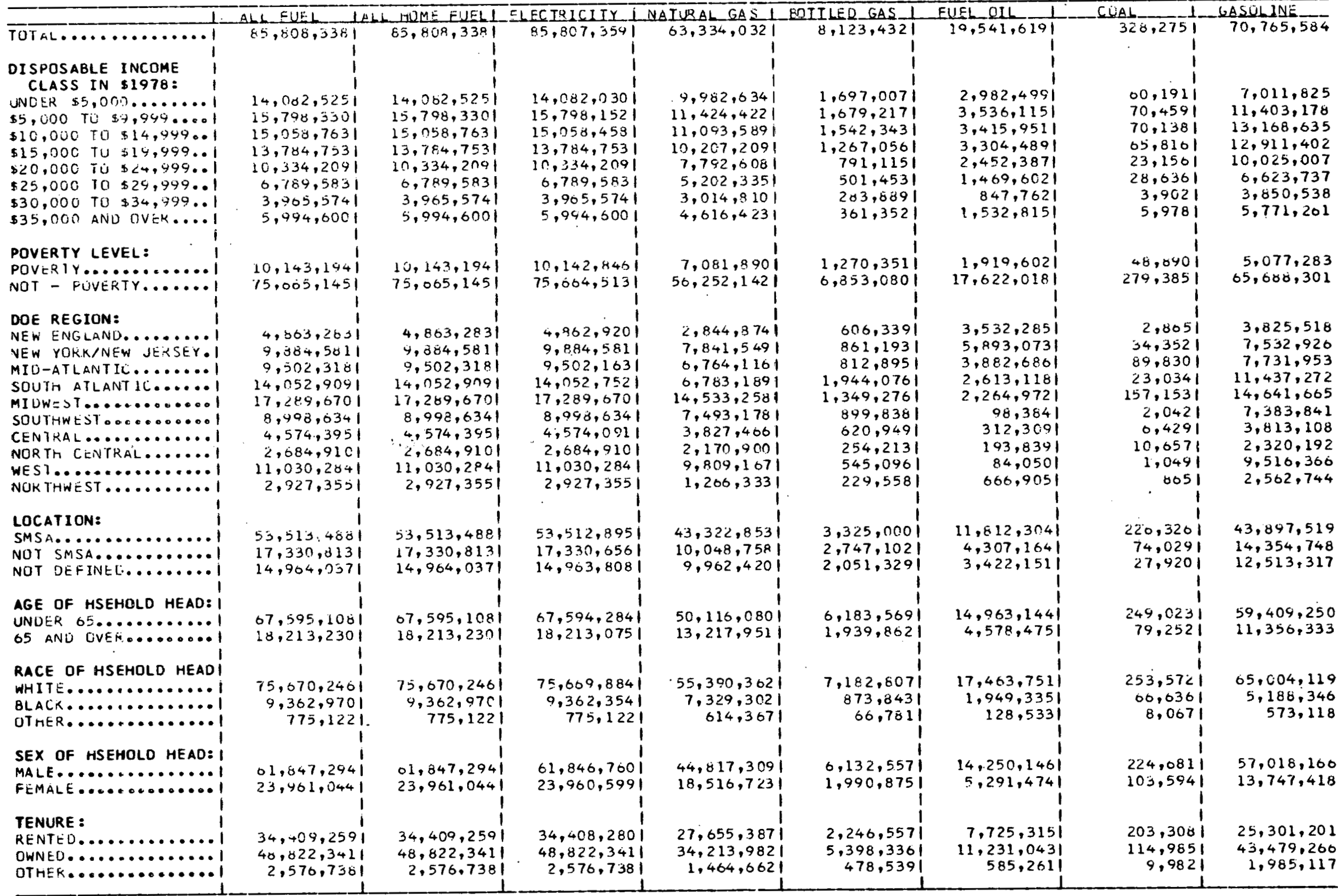


TABLE A. 34

NUMBERS OF ELOEREY HOUSEHOLDS PURCHASING PARTICULAR FUELS- 1985 BY 1978 ARC PROJECTION SERIES C

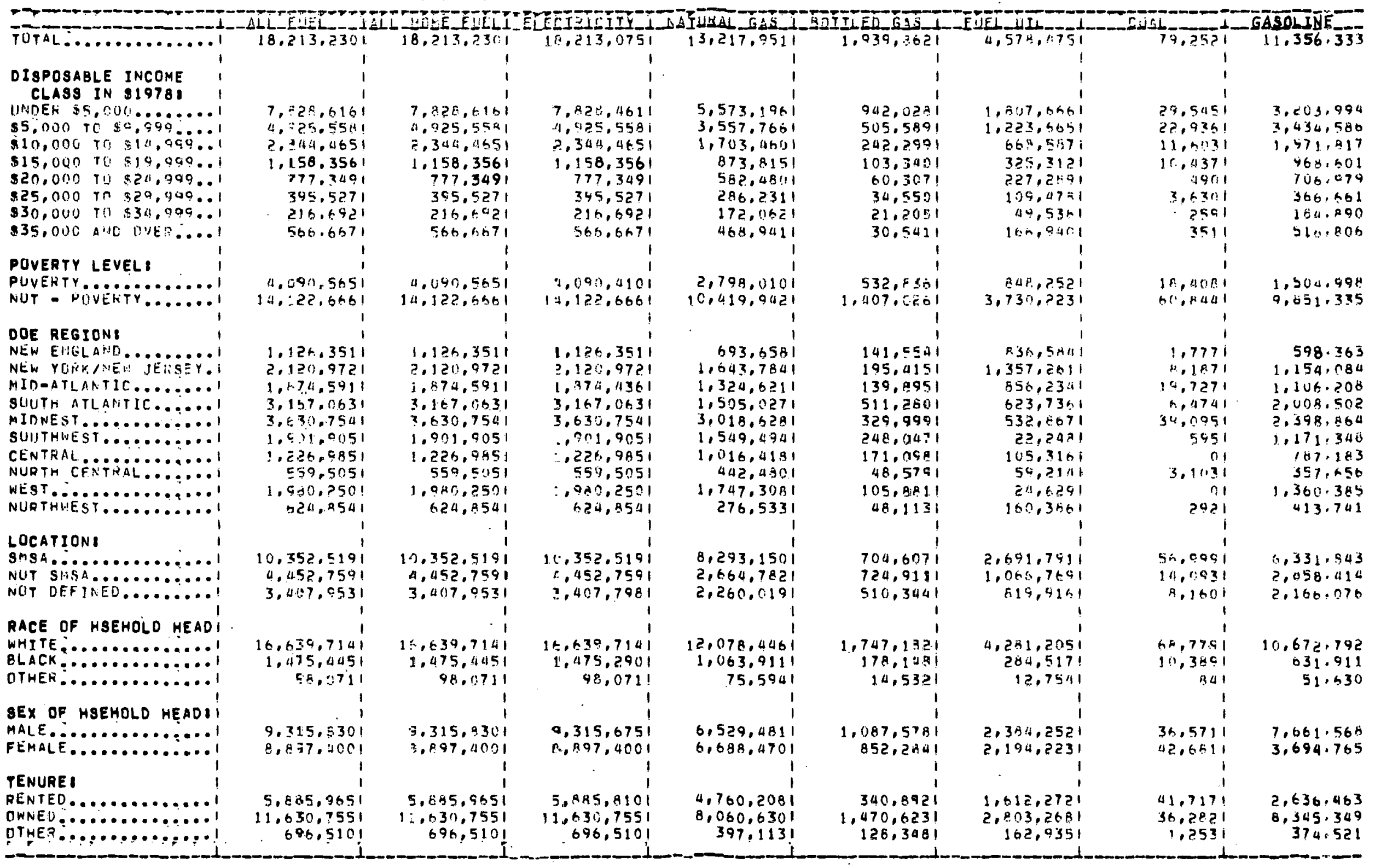

SEE STATISTICAL NOTES 


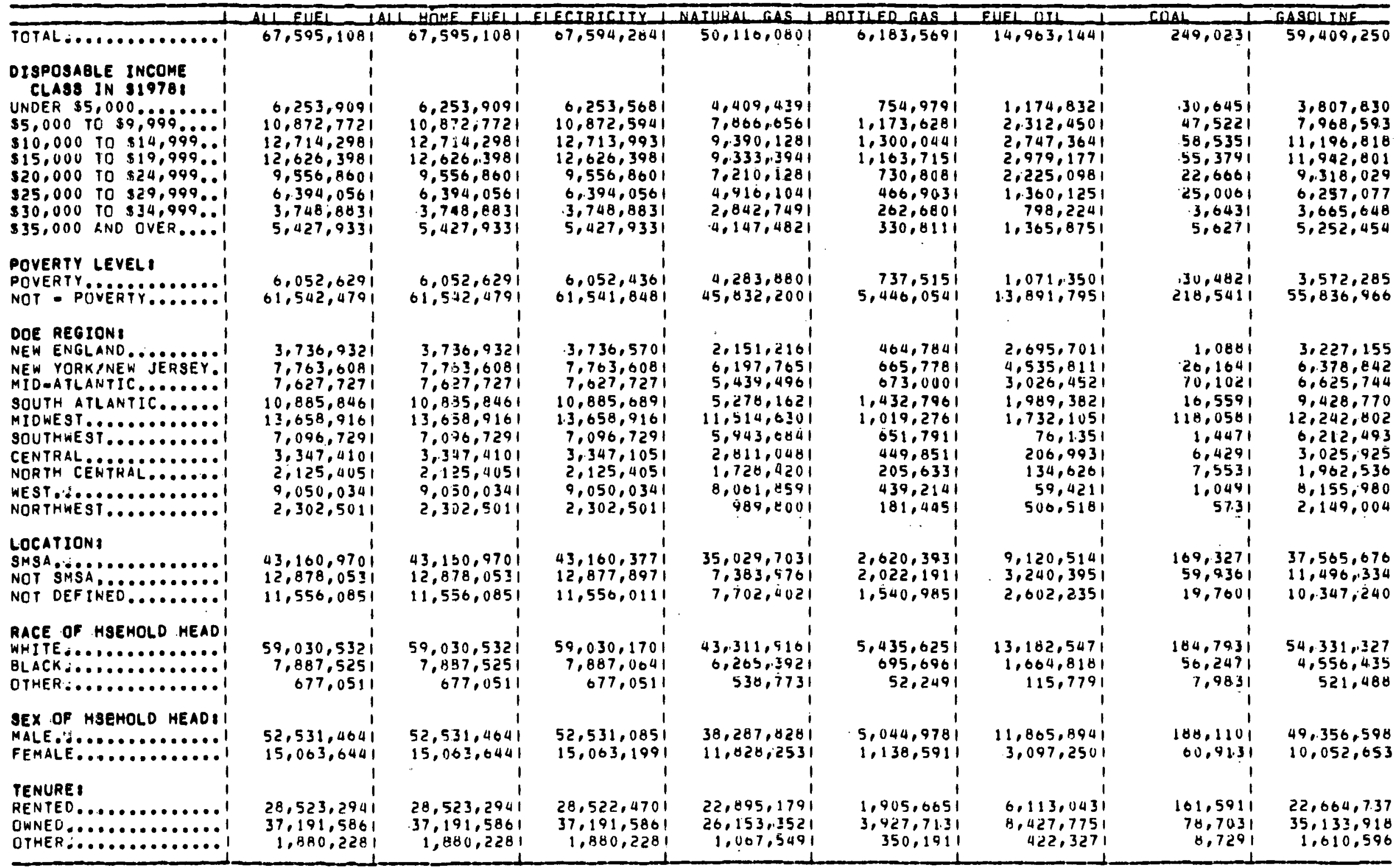


NUMBERS OF PERSONS IN ALL MEUSEHOLDS PURCHASING PARTICJLAR FUELS-O1985 (IN THOUSANDS) BY 1978 ARC PROJECTION SERIES C

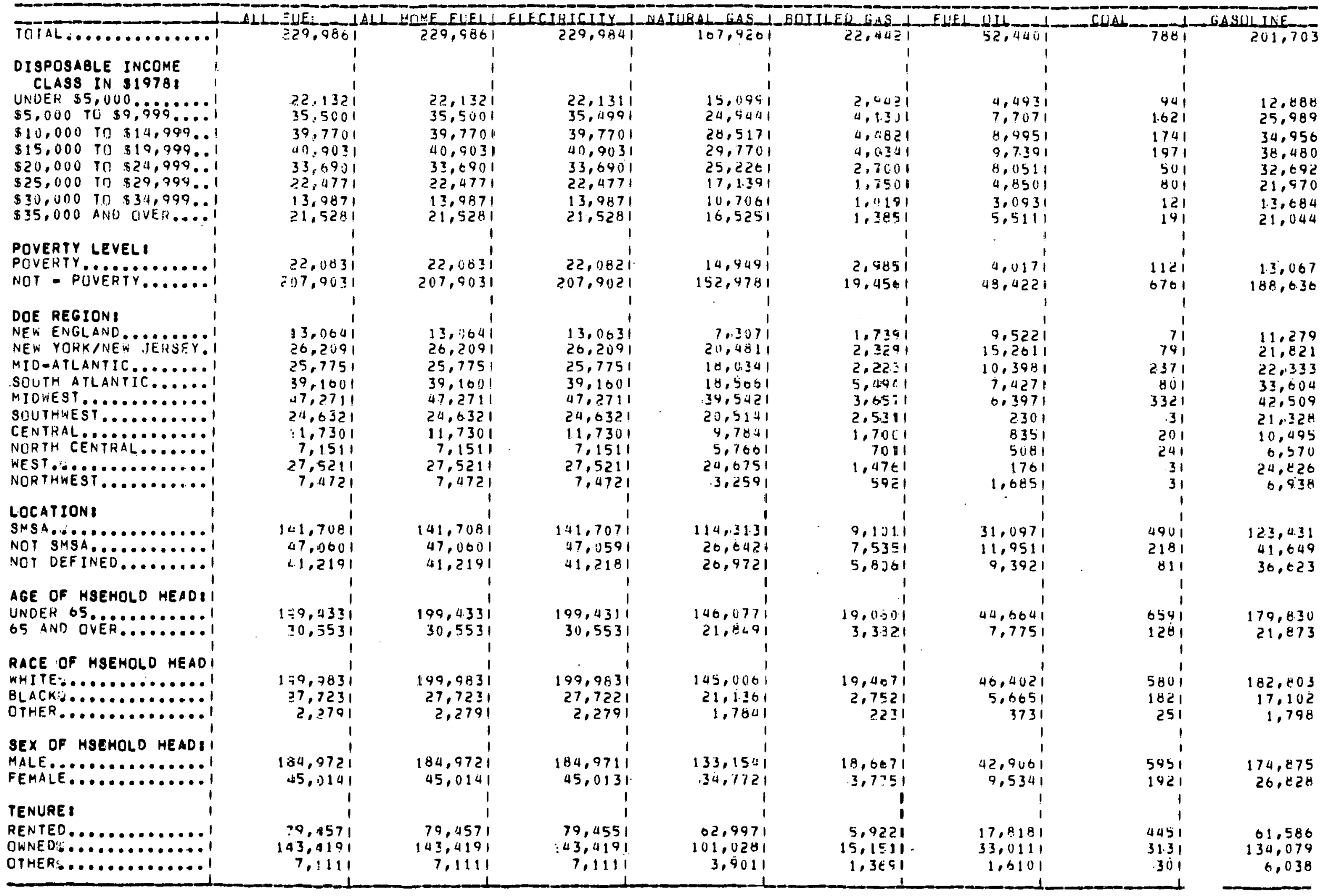




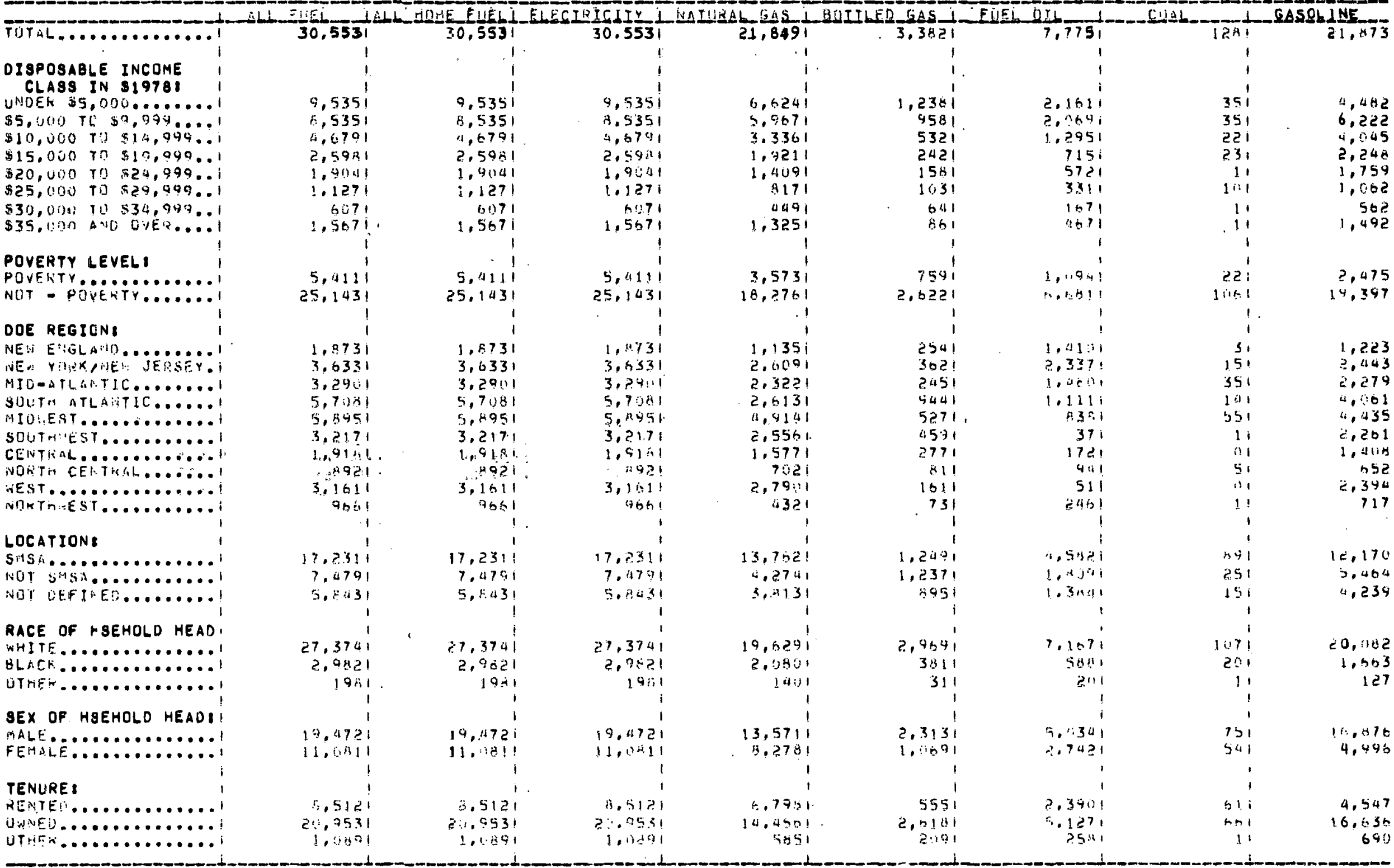


SILON THDILSILYLS IJS

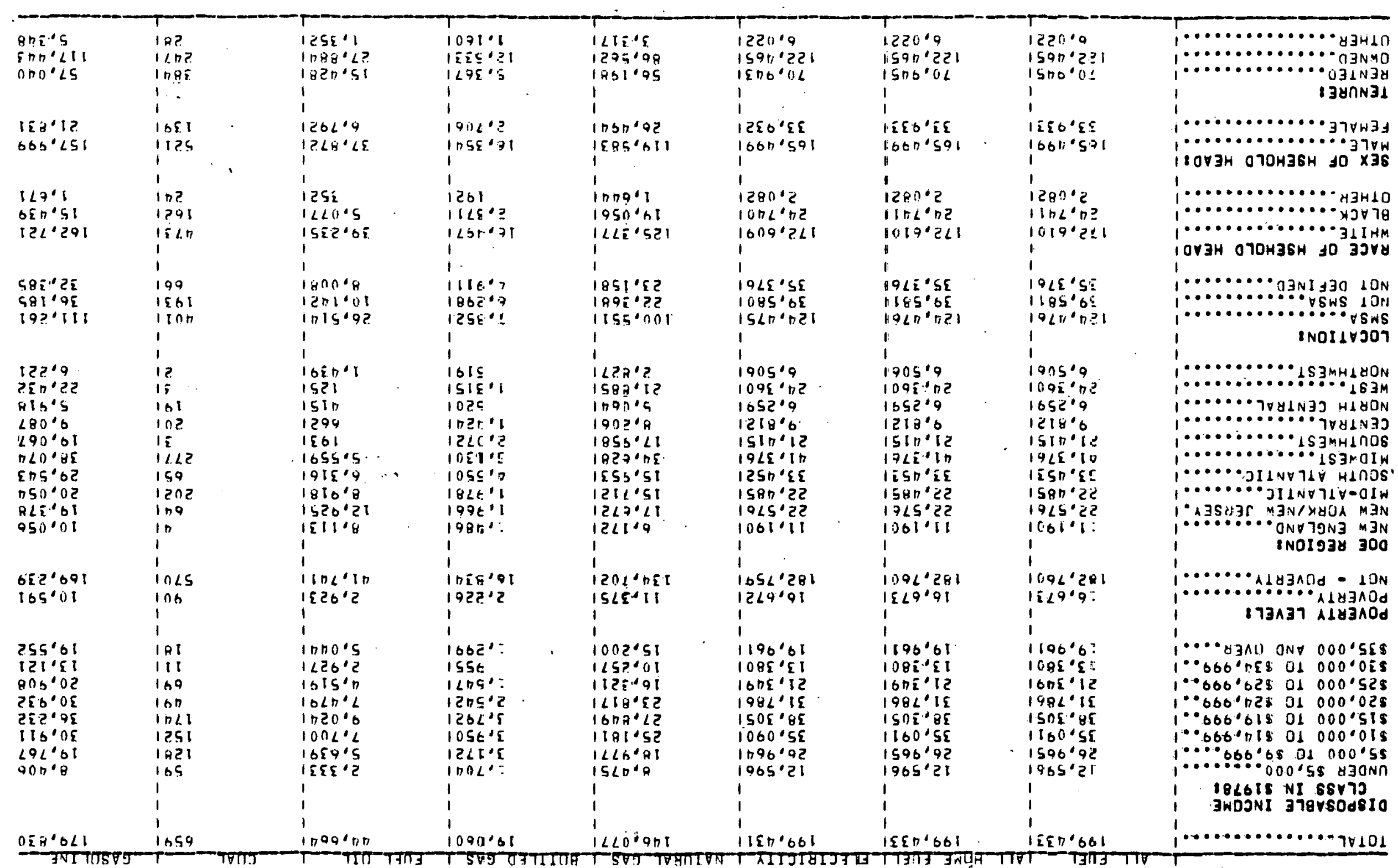

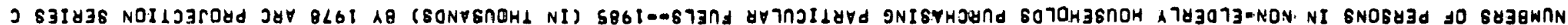


TABLE

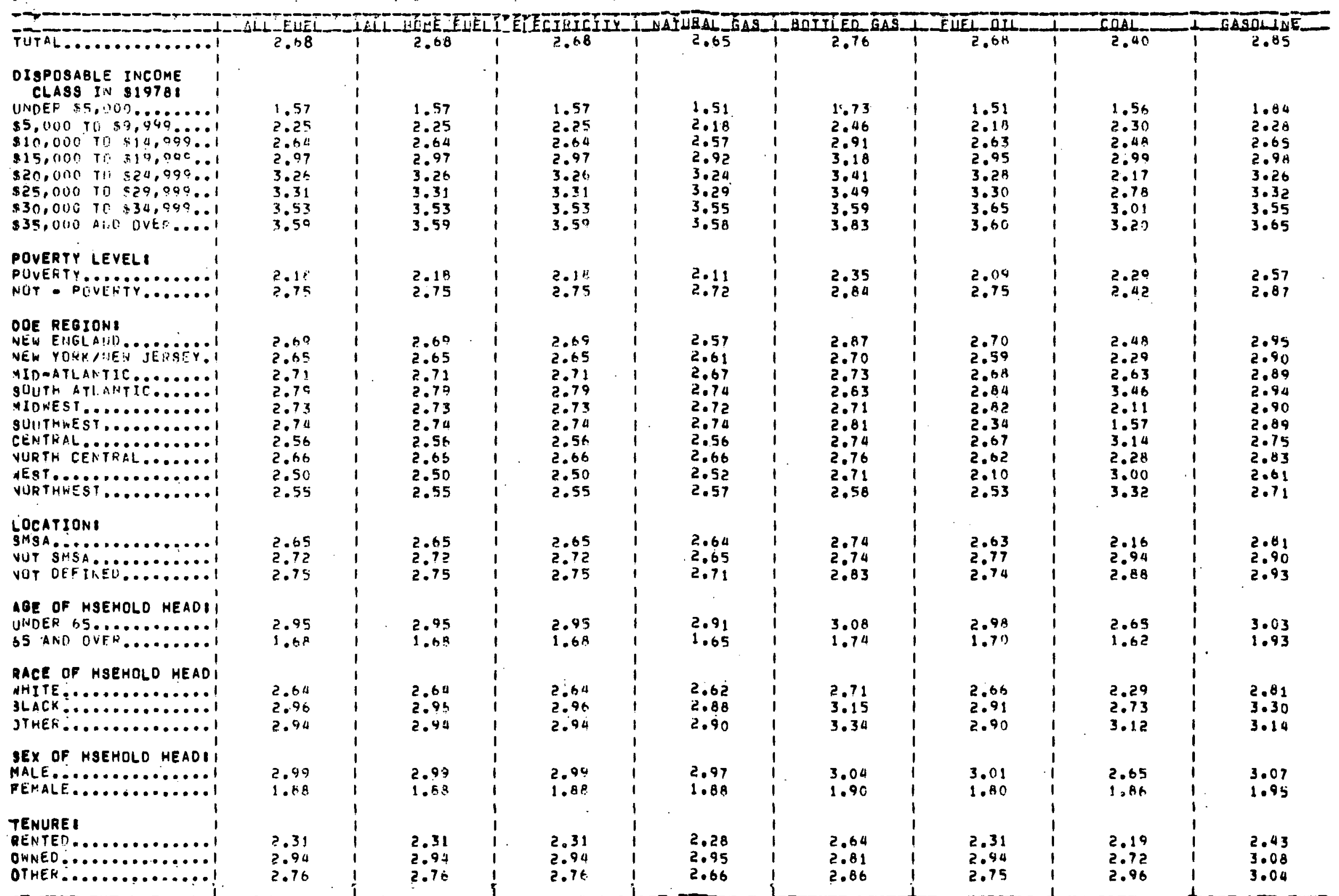

.SEE STATISTICAL NOTES 
TABLE A. 40

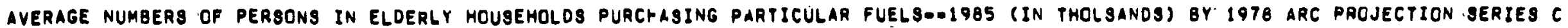

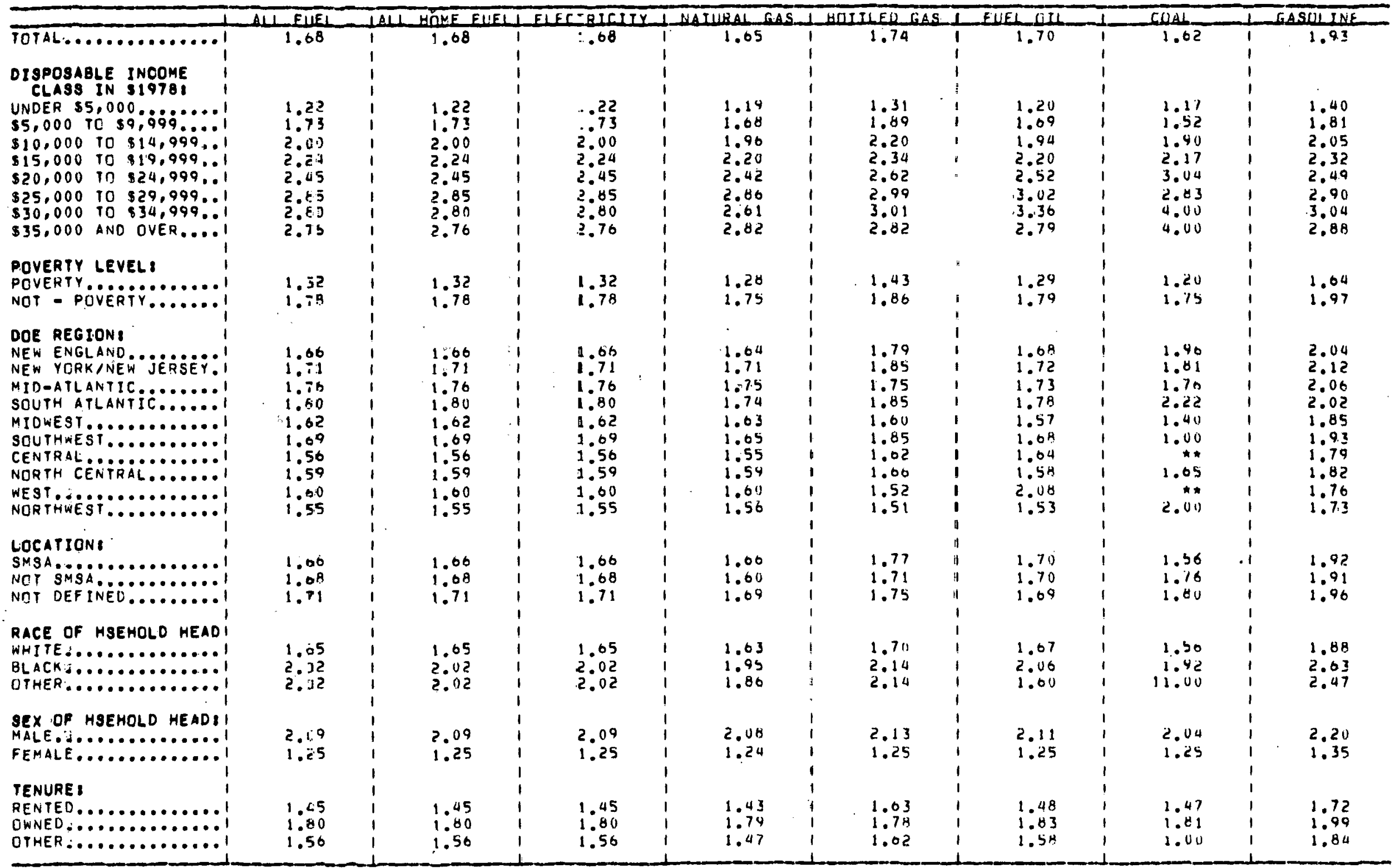

SEE STATISTICAL NCTES 
TABLE A. 41

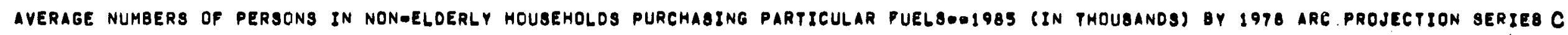

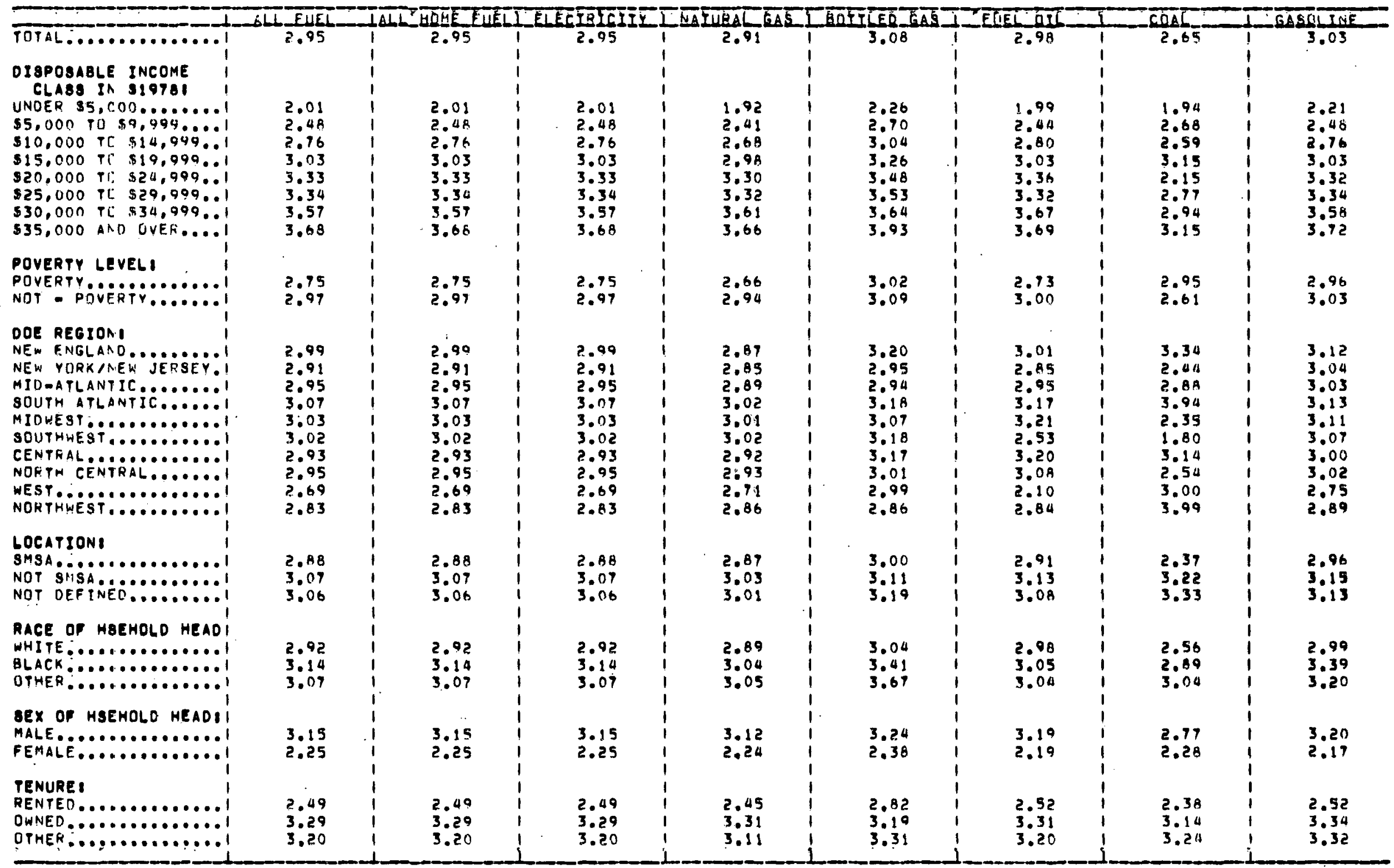

SEE STATISTICAL NOTES 


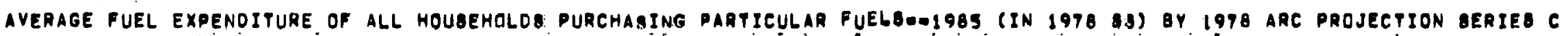

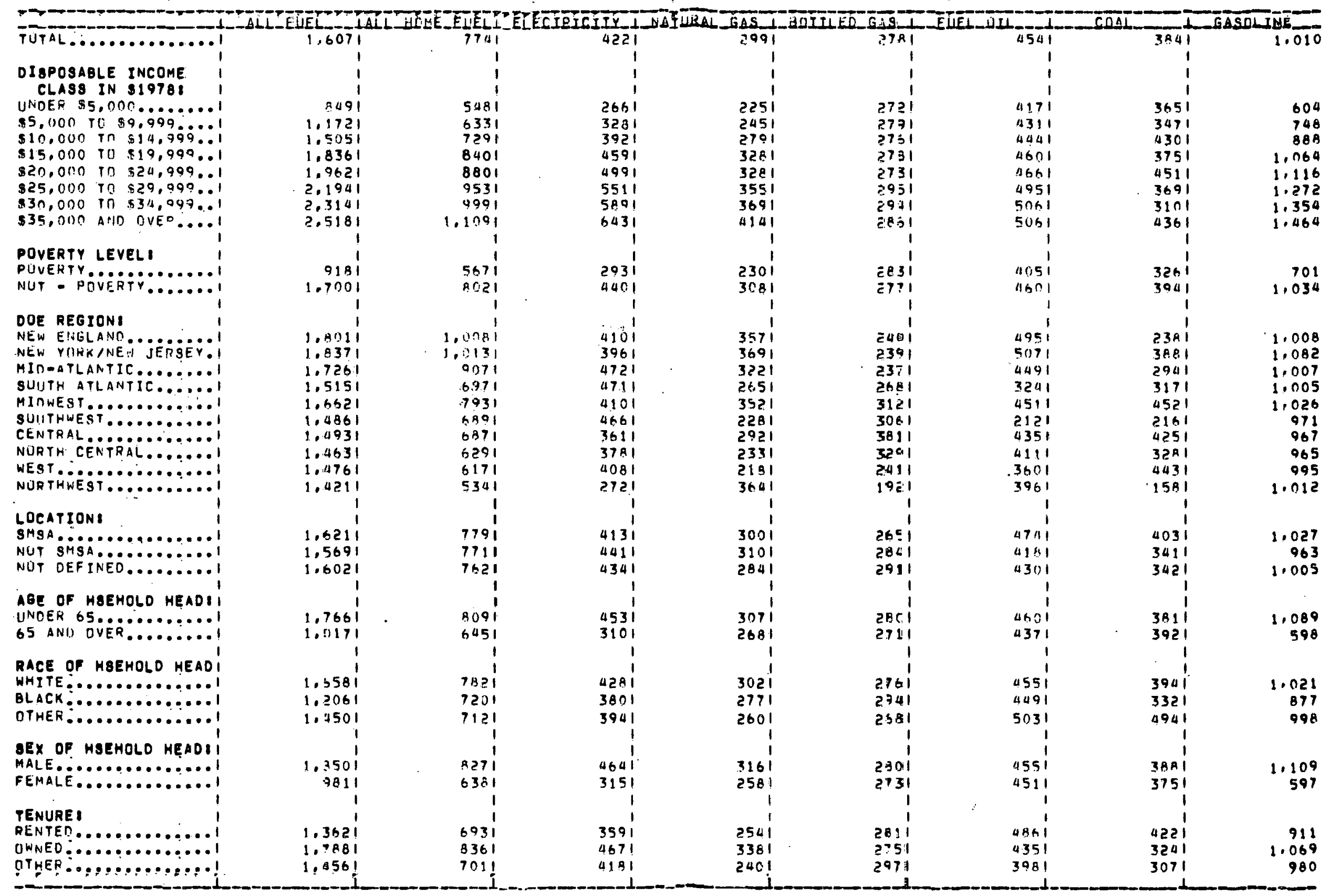

SEE S: STICAL NOTES 


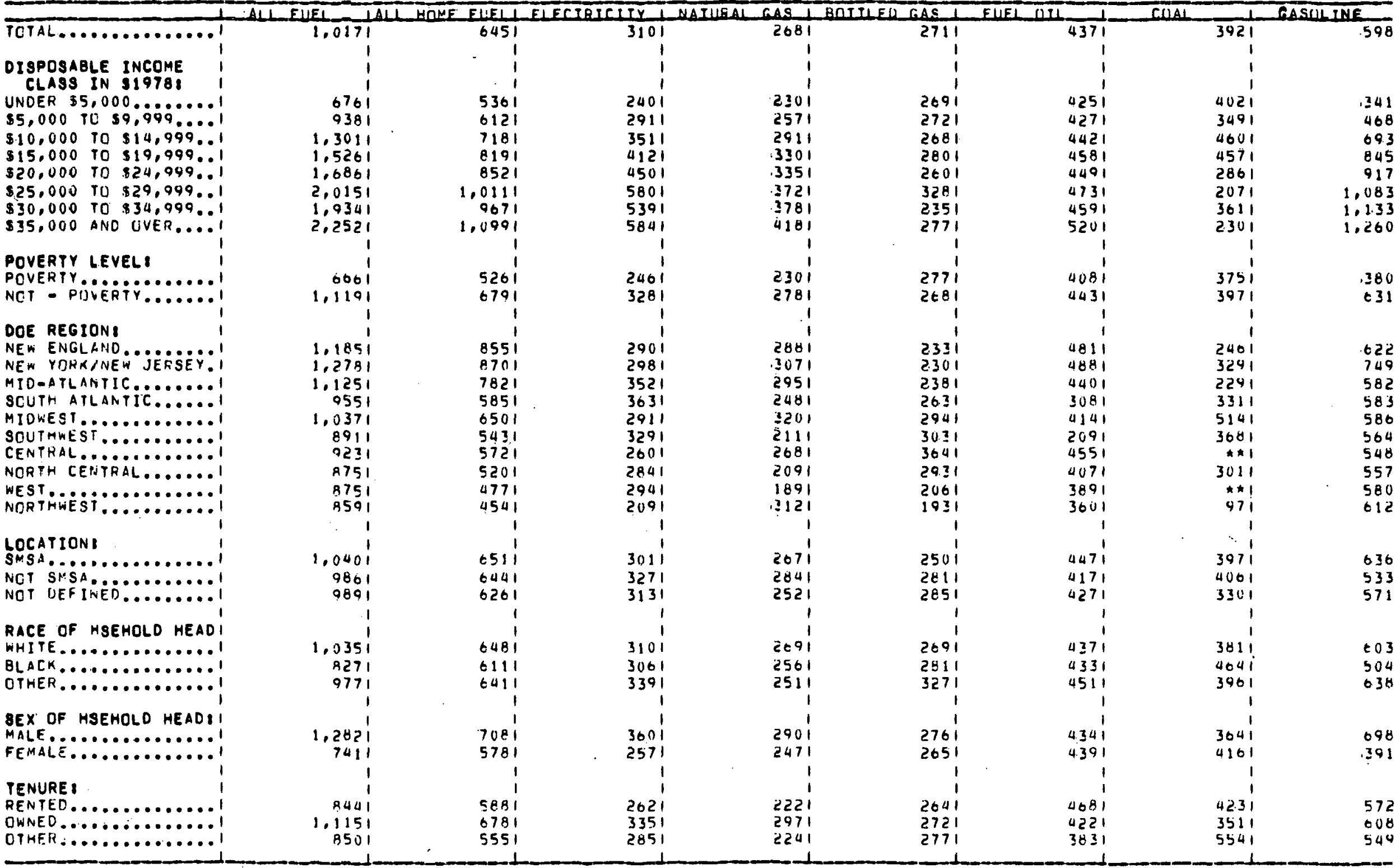

SEE STATISTICAL NOTES 
TABLE A. 44

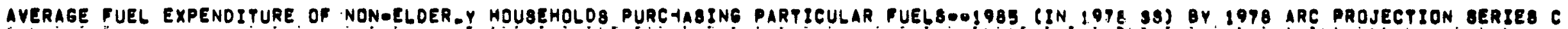

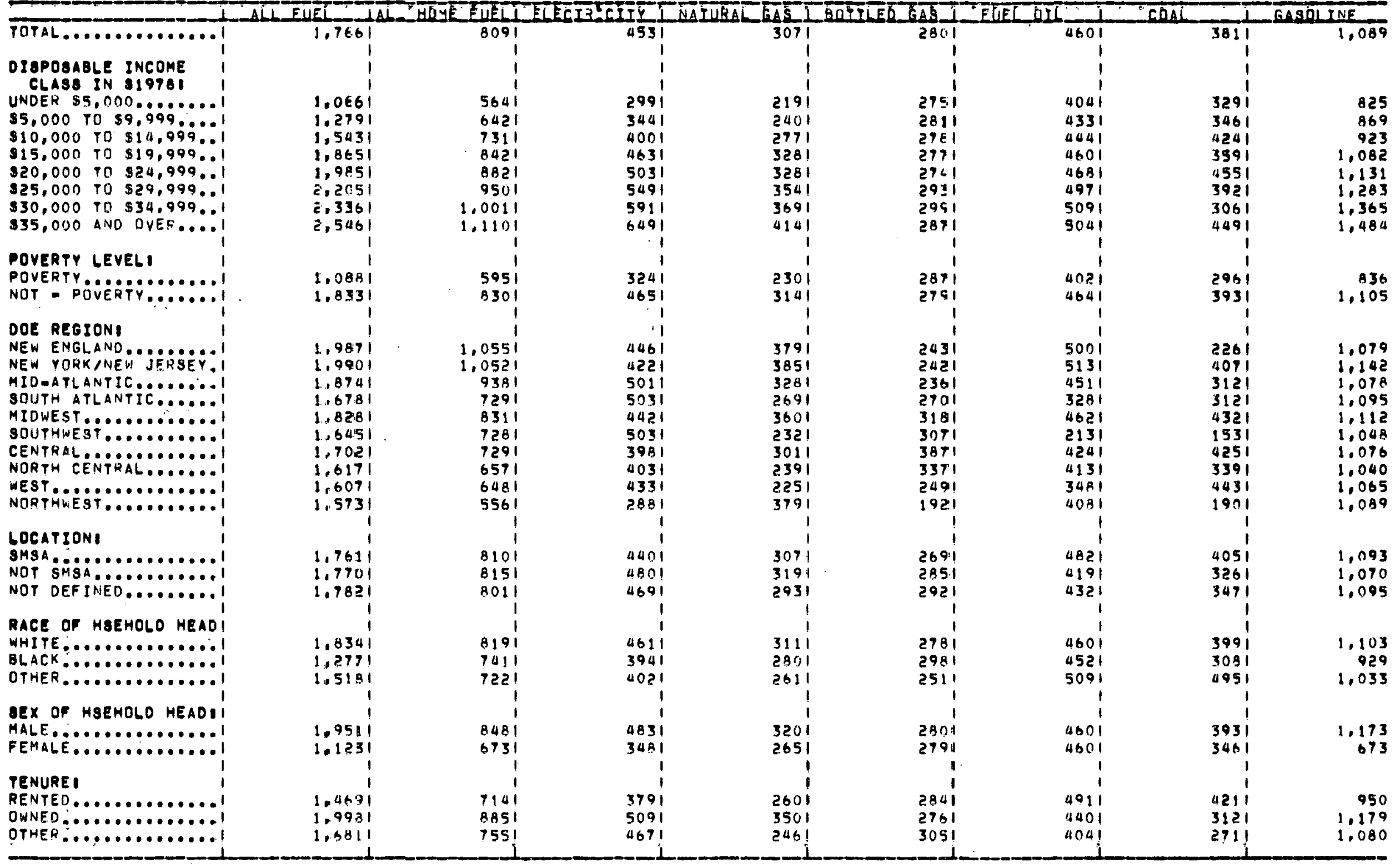

SEE STATISTICAL NOTES 


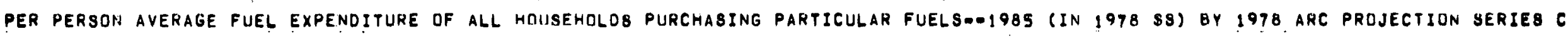

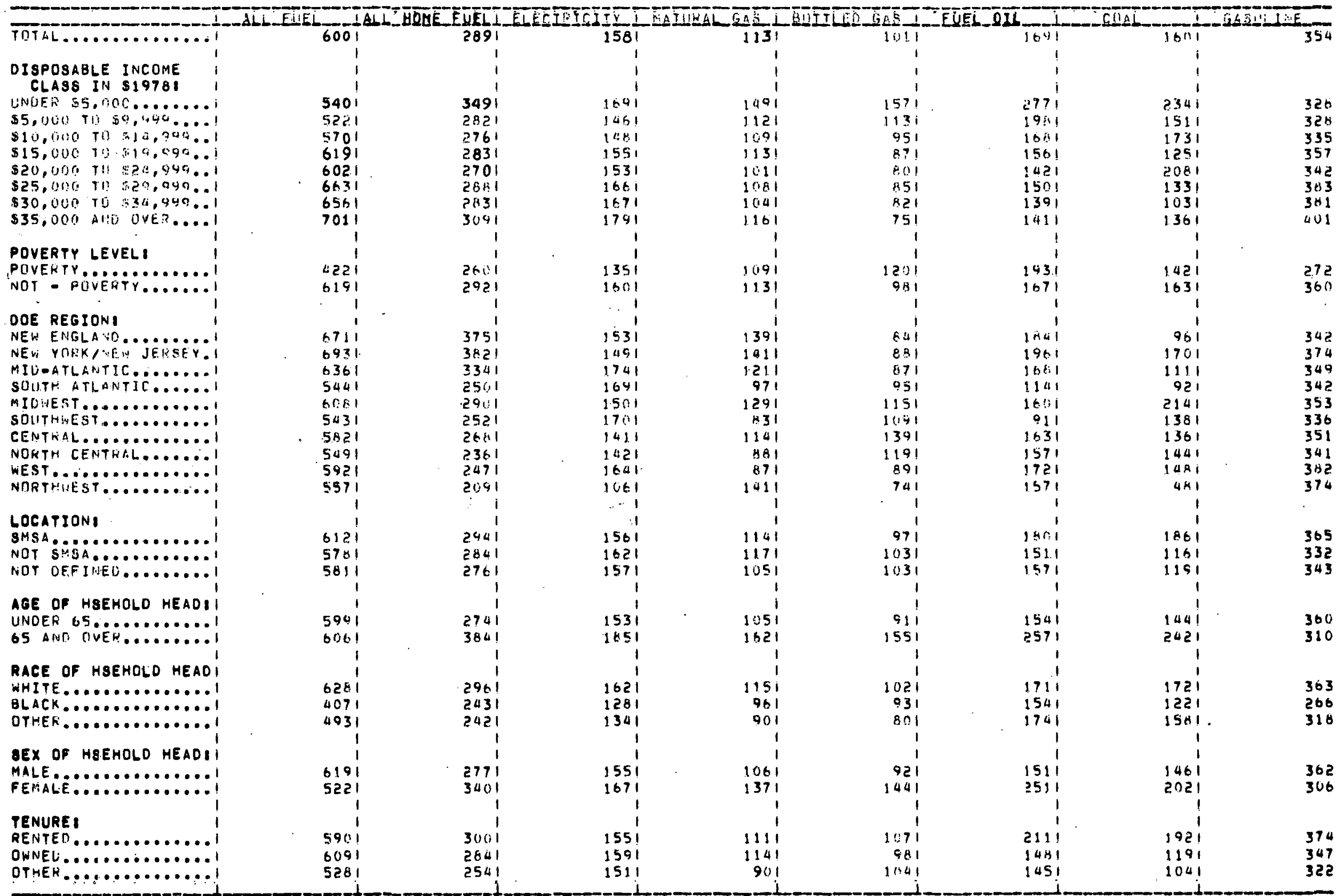

SEE STATISTICAL NOTES 
TABLE A. 46

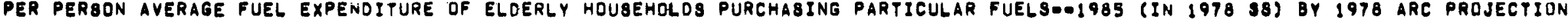
SERIES C

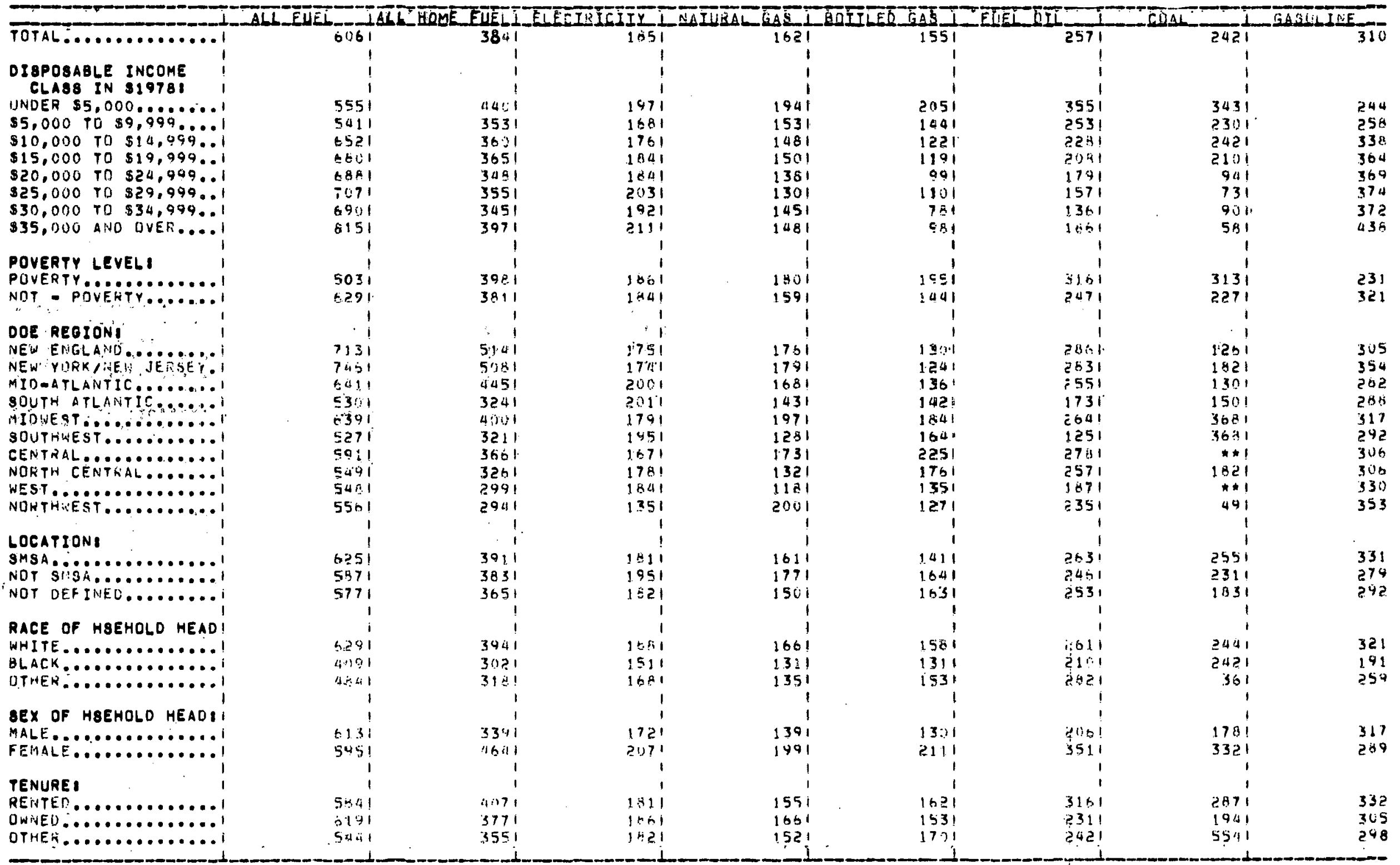

SEE STATISTICAL NOTES 


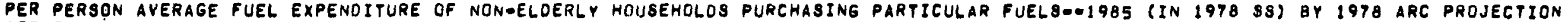
SERIES C

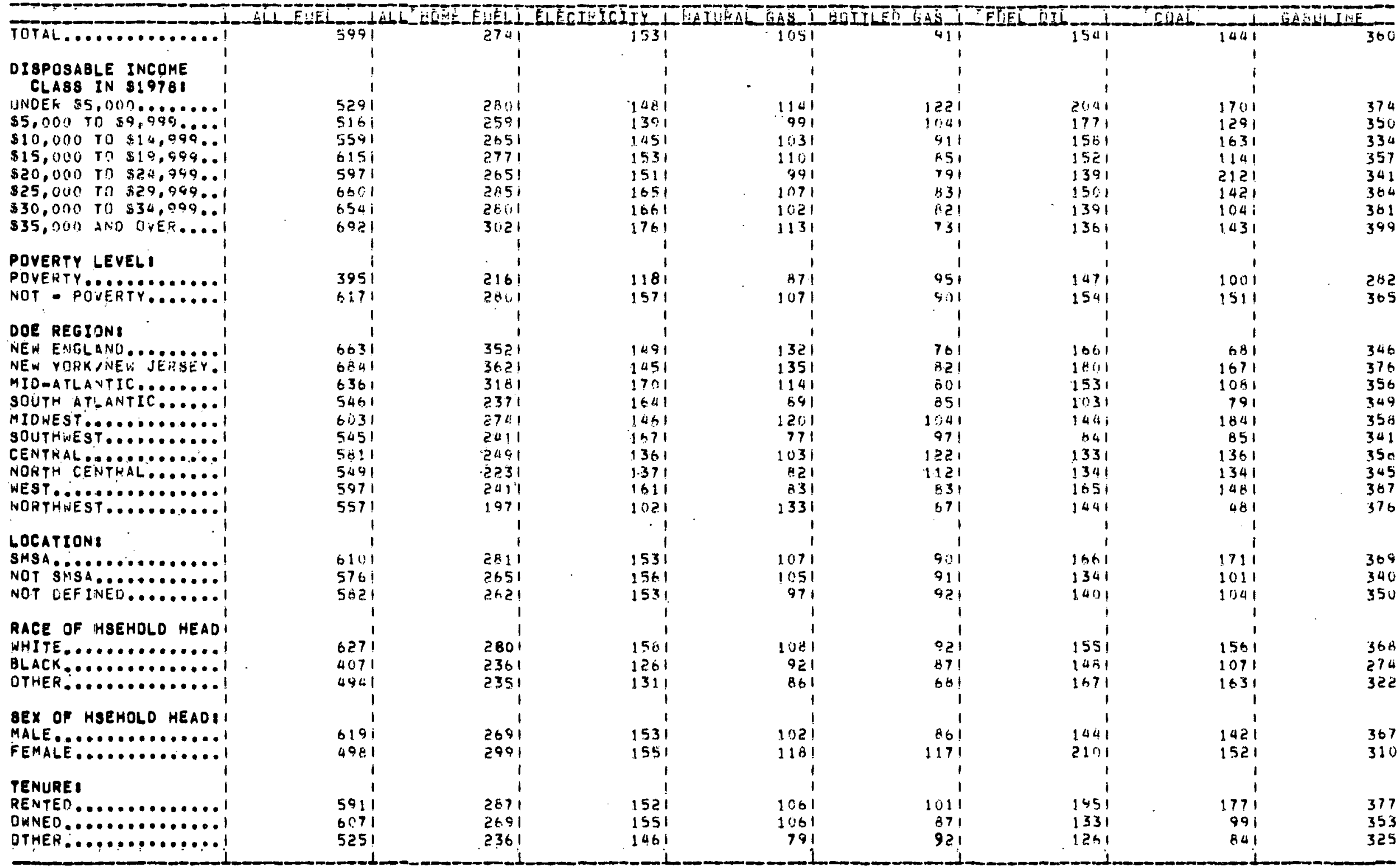

SEE STATISTICAL NOTES 
AVERAGE OIgPOSABLE INOOME OP ALL HOUSEHOLCS PURCHAgING PARTICULAR FUEL80-1985 (IN 1978 S8) BY I978 ARC PROJECTION SERIES C

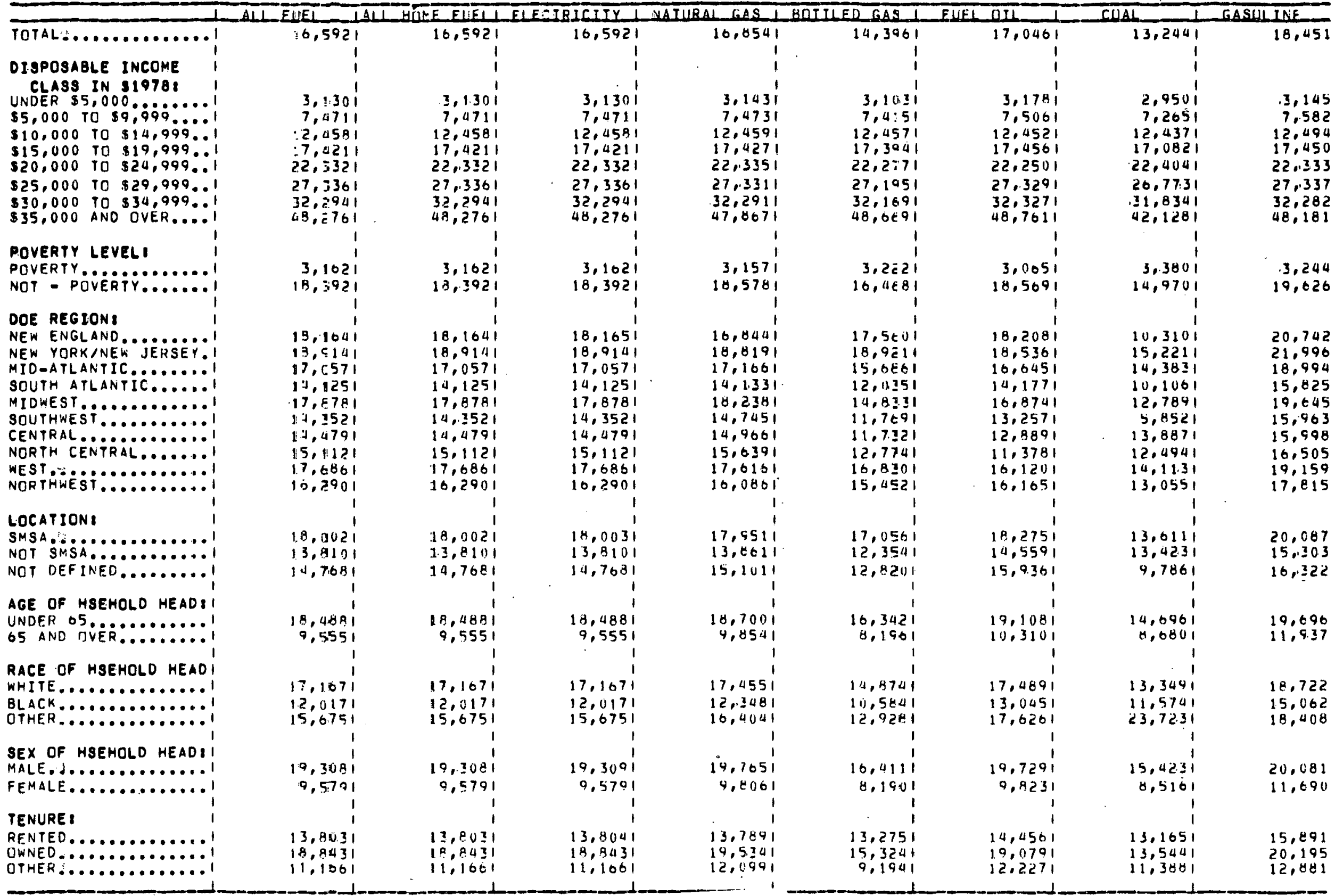


TABLE A. $\$ 9$

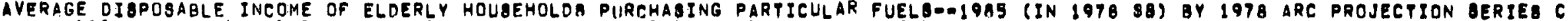

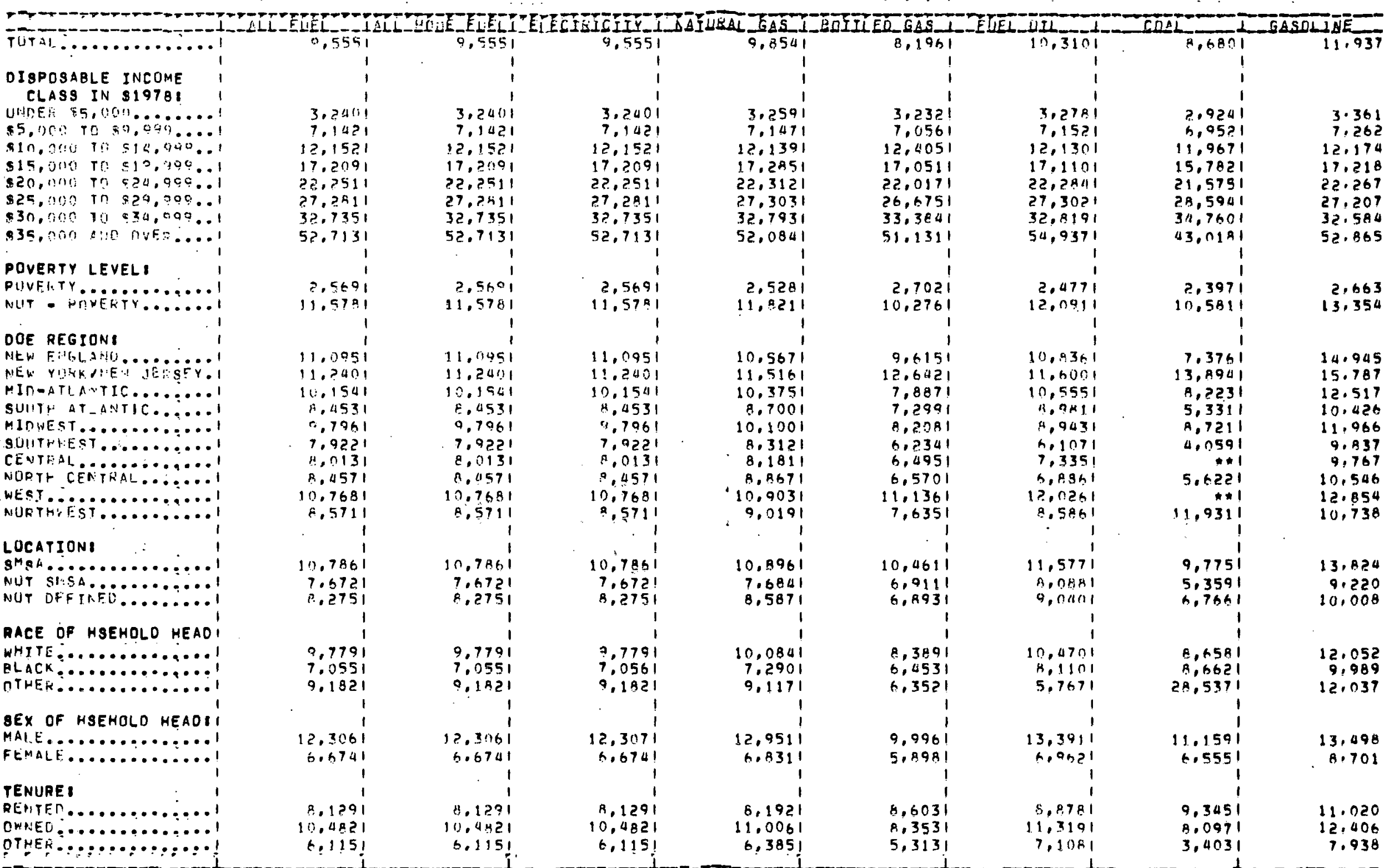

SEE STATISTICAL NOTES 


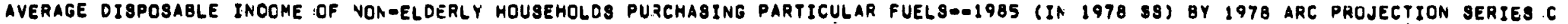

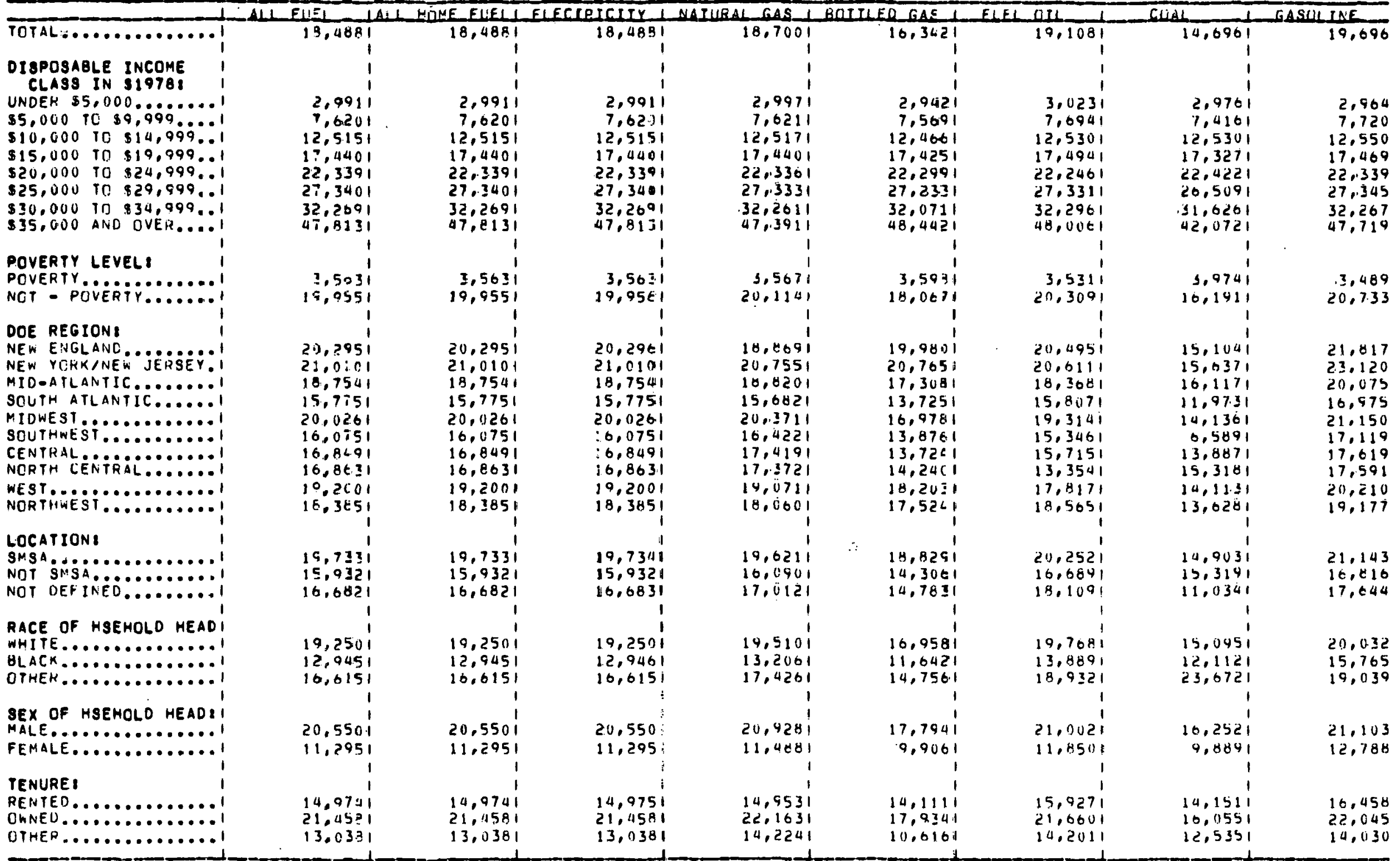

SEE STATISTICAL NOTES 


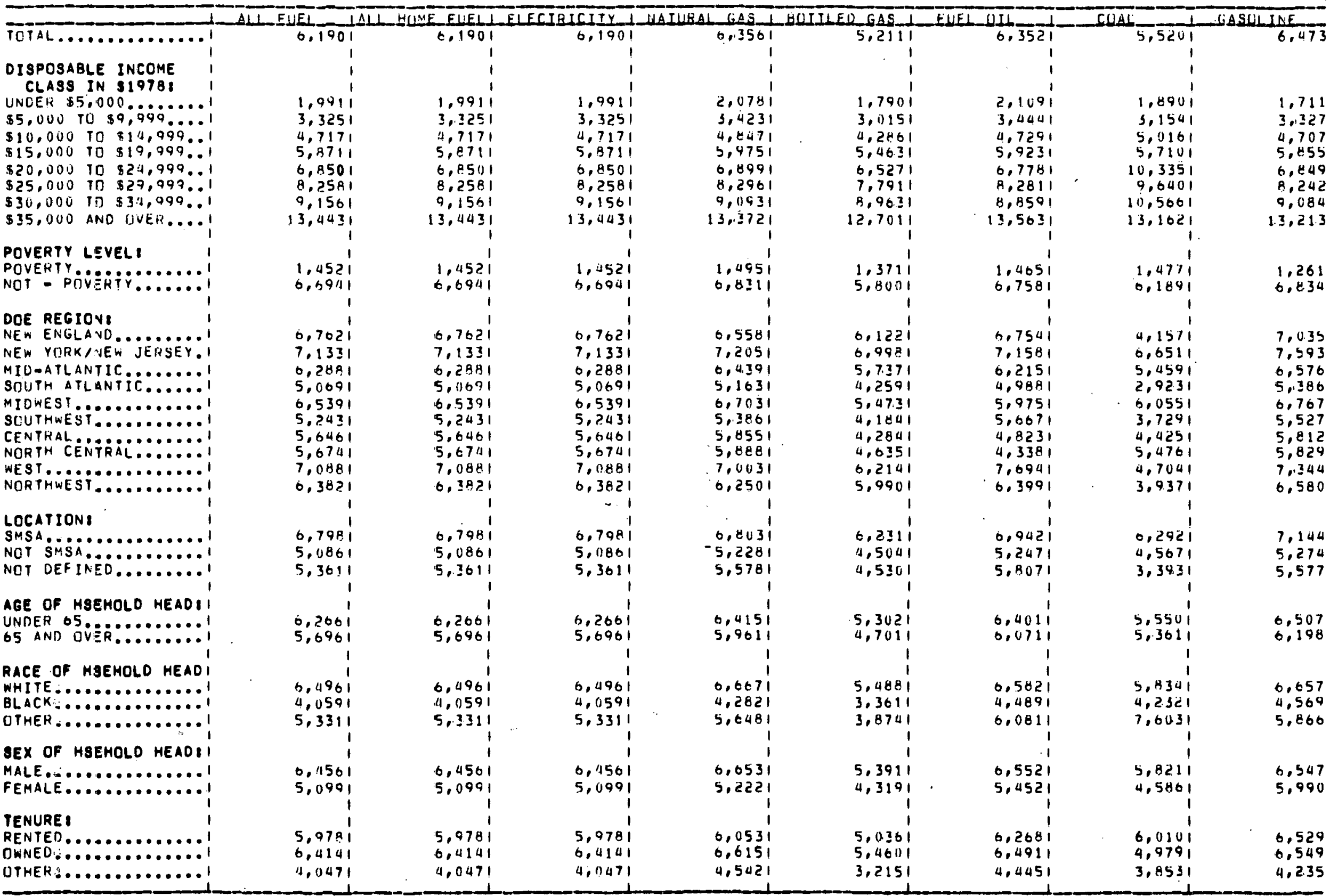

SEE STATISTICAL NOTES 
TABLE A. 52

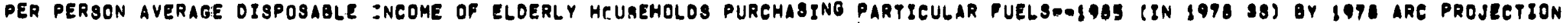
SERIES C

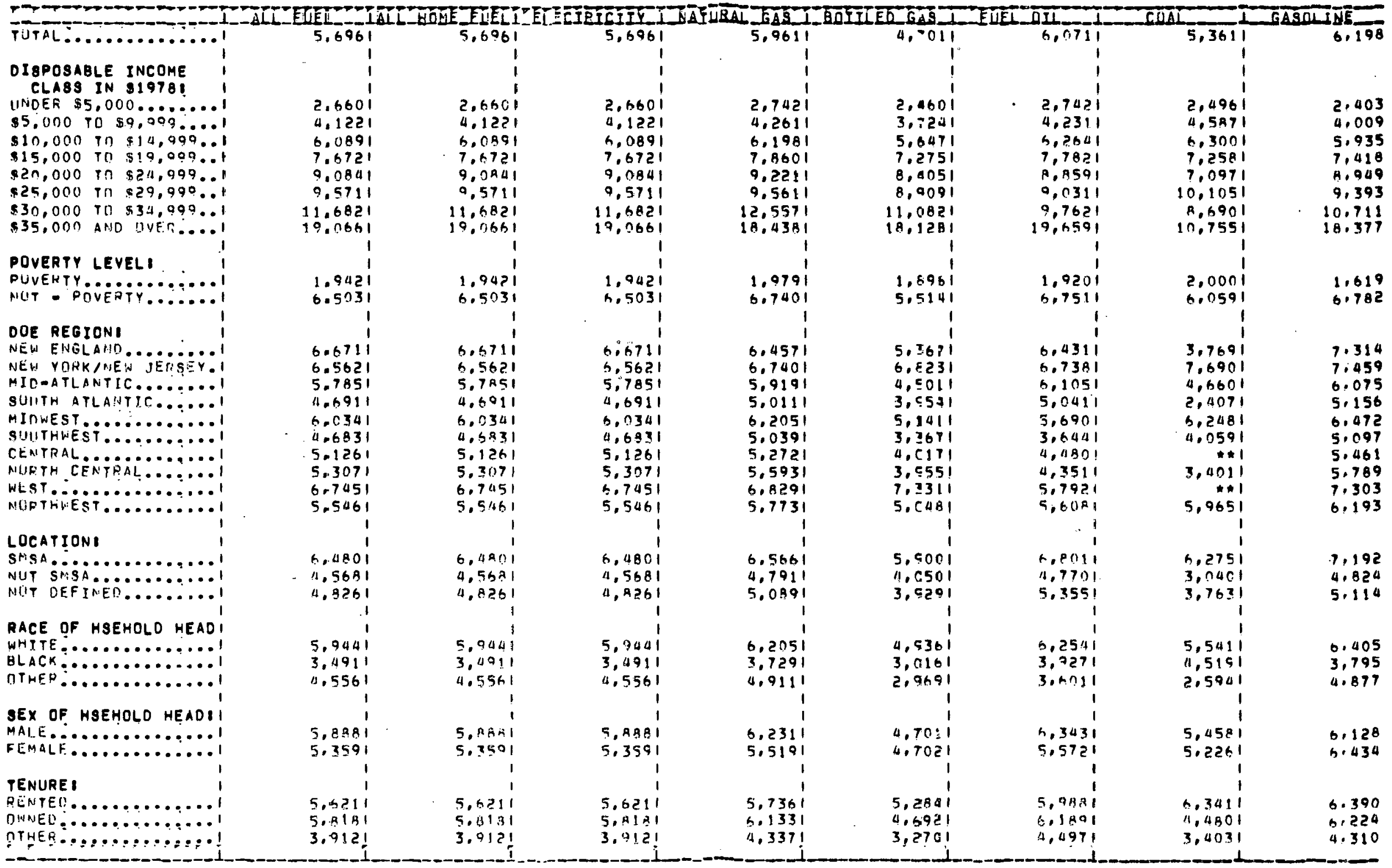

SEE STATISTICAL NOTES 


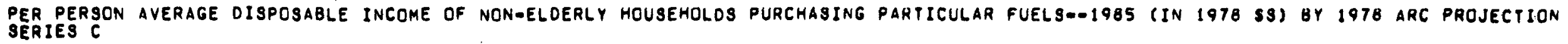

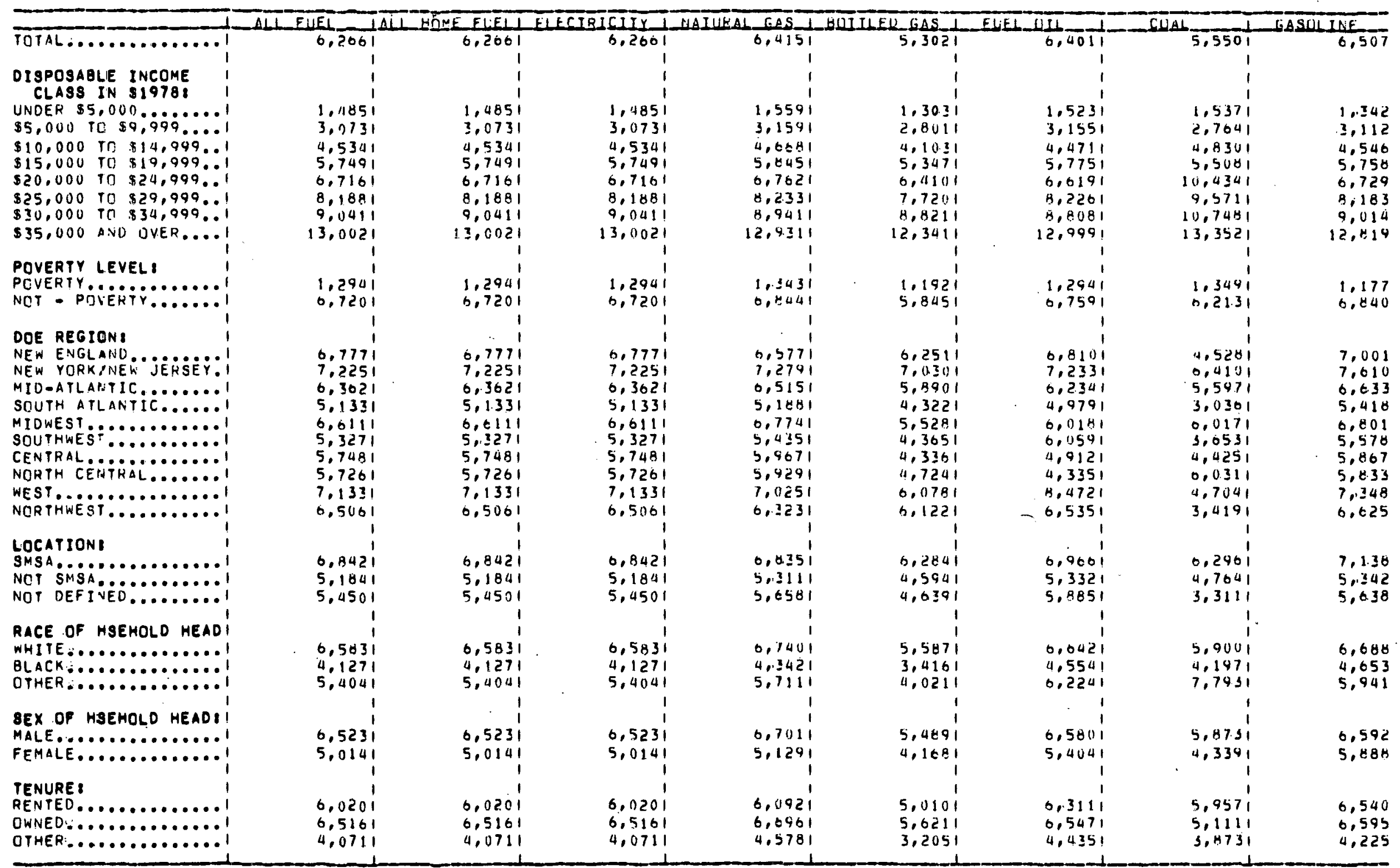

SEE STATISTICAL NOTES 
TABLE A. 54

AVERAGE FUEL EXPENOITURE OF ALL hOU.3EHOLOS AS A PERCENT OF OISPOSABLE INCOME--1985 bY 1978 aRC PROJECTION SERIES $C$

\begin{tabular}{|c|c|c|c|c|c|c|c|c|c|c|c|c|c|c|c|}
\hline \multirow{3}{*}{ TOTAL $\ldots \ldots \ldots \ldots \ldots \ldots$} & $A \perp \perp E \perp E \perp$ & $111 L$ & AOHE E & EliELL L & ELETIRICIIY & سـا & NAIUBAL GAS & 1 & BCIIIEU RIES & $\perp$ & EUE L & -1. & CUal & \multicolumn{2}{|c|}{ - GASOLINE } \\
\hline & 9.59 & 1 & 4.67 & 1 & 2.55 & 1 & 1.77 & 1 & 1.9 .3 & 1 & 2.67 & 1 & 2.90 & 1 & 5.47 \\
\hline & & 1 & & 1 & & 1 & & 1 & & 1 & & 1 & & 1 & \\
\hline DISPOSABLE INCOME I & & 1 & & 1 & & 1 & & 1 & & 1 & & 1 & & 1 & \\
\hline CLASS IN 919781 & & 1 & & 1 & & 1 & & 1 & & 1 & & 1 & & 1 & \\
\hline 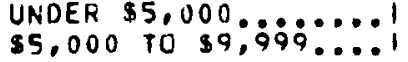 & $\begin{array}{l}27.13 \\
15: 59\end{array}$ & 1 & 17.52 & 1 & 8.51 & 1 & 7.10 & 1 & 8.75 & 1 & 1.3 .12 & 1 & 12,26 & 1 & 19.19 \\
\hline $\begin{array}{l}\$ 5,000 \\
\$ 10,000 \text { 10 } \$ 14,999 \ldots 1\end{array}$ & $\begin{array}{l}15.59 \\
12.38\end{array}$ & $\begin{array}{l}1 \\
1\end{array}$ & $\begin{array}{l}8.47 \\
5.85\end{array}$ & 1 & $\begin{array}{l}4.39 \\
.3 .15\end{array}$ & $\begin{array}{l}1 \\
1\end{array}$ & $\begin{array}{l}13.28 \\
2.24\end{array}$ & $i$ & $\begin{array}{l}3.76 \\
2.22\end{array}$ & 1 & $\begin{array}{l}5.74 \\
.3 .56\end{array}$ & 1 & $\begin{array}{l}4.14 \\
3.46\end{array}$ & 1 & 9.86 \\
\hline$\$ 15,000$ TD $819,999 . .1$ & 10.54 & 1 & $4.8 ?$ & 1 & 2.63 & 1 & 1.88 & 1 & 1.60 & 1 & $\begin{array}{l}3.36 \\
2.04\end{array}$ & $i$ & $\begin{array}{l}3.46 \\
2.19\end{array}$ & 1 & .11 \\
\hline$\$ 20,000 \quad 70 \$ 24,999 \ldots 1$ & 8.79 & 1 & 3.94 & 1 & 2.24 & 1 & 1.47 & 1 & 1.22 & 1 & 2.10 & 1 & 2.02 & 1 & 5.00 \\
\hline 525,000 TO $529,999 \ldots 1$ & 8.1 .3 & 1 & 3.49 & 1 & 2.02 & 1 & 1.30 & 1 & 1.09 & 1 & 1.81 & 1 & 1.38 & 1 & 4.65 \\
\hline $530,000 \quad 10834,999 \ldots 1$ & 7.16 & 1 & 3.09 & 1 & 1.82 & 1 & 1.14 & 1 & .92 & 1 & 1.57 & 1 &. .47 & 1 & 4.20 \\
\hline$\$ 35,000$ AND DVER....! & 5.22 & 1 & 2.30 & 1 & 1.33 & 1 & .87 & 1 & .59 & 1 & 1.04 & 1 & 1.04 & 1 & 3.04 \\
\hline - 1 & & 1 & & 1 & & 1 & & 1 & & 1 & & 1 & & 1 & \\
\hline POVERTY LEVEL: & & 1 & & 1 & & 1 & & I & & 1 & & 1 & & 1 & \\
\hline POVERTY ............ & 29.02 & 1 & $: 7.93$ & 1 & 9.27 & 1 & 7.27 & 1 & 0.78 & 1 & 1.3 .21 & 1 & 9.04 & 1 & 21.01 \\
\hline NOT - POVERTY...... ! & 9.24 & 1 & 4.36 & 1 & 2.39 & 1 & 1.60 & 1 & 1.68 & 1 & 2.48 & 1 & 2.63 & 1 & 5.27 \\
\hline DOE REGION: & & 1 & & i & & 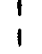 & & 1 & & 1 & & $\begin{array}{l}1 \\
1\end{array}$ & & $\begin{array}{l}1 \\
1\end{array}$ & \\
\hline VEW ENGLAND....... I & 9.92 & $i$ & 5.55 & 1 & 2.26 & 1 & 2.12 & 1 & 1.37 & 1 & 2.72 & 1 & 2.31 & $i$ & 4.86 \\
\hline NEW YORK/NEW JERSEY.I & 9.71 & 1 & 5.35 & 1 & 2.09 & 1 & 1.96 & 1 & 1.26 & 1 & 2.74 & 1 & 2.55 & 1 & 4.92 \\
\hline MID-ATLANTIC $\ldots \ldots \ldots$ I & $10 .: 2$ & 1 & 5.32 & 1 & 2.76 & 1 & 1.87 & 1 & 1.51 & 1 & 2.70 & 1 & 2.04 & 1 & 5.30 \\
\hline SOUTH ATLANTIC...... ! & 10.72 & 1 & 4.93 & 1 & -3.34 & 1 & 1.87 & 1 & 2.23 & 1 & 2.28 & 1 & 3.14 & 1 & 6.35 \\
\hline YIDWEST $\ldots \ldots \ldots \ldots \ldots \ldots$. . . & 9.30 & 1 & 4.44 & 1 & 2.29 & 1 & 1.93 & 1 & 2.10 & 1 & 2.07 & 1 & 3.54 & 1 & $5.2 ?$ \\
\hline SOUTHWEST . . . . . . . . . I & 10.35 & 1 & 4.80 & 1 & .3 .25 & 1 & 1.55 & 1 & 2.00 & 1 & 1.60 & 1 & 3.69 & 1 & $6.0 \%$ \\
\hline 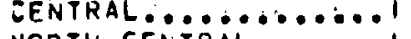 & 10.31 & 1 & 4.74 & 1 & 2.49 & $\mathbf{I}$ & 1.95 & 1 & 3.24 & 1 & .2 .37 & 1 & 3.06 & 1 & 0.05 \\
\hline VORTH CENTRAL........ & $9 .=8$ & 1 & 4.16 & 1 & 2.50 & 1 & 1.49 & $\mathbf{I}$ & 2.57 & 1 & .3 .01 & 1 & 2.63 & 1 & 5.85 \\
\hline NEST_............. & 8.2 .4 & 1 & 3.49 & 1 & 2.31 & 1 & 1.24 & 1 & 1.43 & 1 & 2.23 & 1 & 3.14 & 1 & 5.19 \\
\hline VORTHWEST .......... & 8.72 & 1 & $3.2^{\AA}$ & 1 & 1.67 & 1. & 2.26 & 1 & 1.24 & 1. & 2.45 & 1 & 1.21 & I & 5.68 \\
\hline LOCATIONI & & 1 & & 1 & & 1 & & 1 & & 1 & & 1 & & $!$ & \\
\hline $\begin{array}{l}\text { LOCATIONI } \\
\text { SMSA. } \ldots \ldots \ldots \ldots \ldots \ldots\end{array}$ & & 1 & & 1 & & 1 & & I & & 1 & & 1 & & 1 & \\
\hline SMSA $\ldots \ldots \ldots \ldots \ldots \ldots$ & $9 .: 1$ & 1 & 4.33 & 1. & 2.30 & 1 & 1.07 & I & 1.56 & 1 & 2.60 & 1 & 2.40 & 1 & 5.11 \\
\hline WOI SNSA $\ldots \ldots \ldots \ldots \ldots$ & $11 \cdot 50$ & 1 & 5.58 & 1 & 3.19 & 1 & 2.24 & 1 & 2.30 & 1 & 2.87 & 1 & 2.54 & 1 & 6.30 \\
\hline NOT DEF INEO ......... & $10 . .5$ & 1 & 5.16 & 1 & 2.94 & 1 & 1.88 & 1 & 2.27 & 1 & 2.70 & 1 & 3.50 & 1 & 0.16 \\
\hline 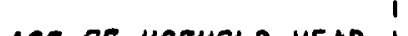 & & 1 & & 1 & & 1 & & 1 & & 1 & & 1 & & 1 & \\
\hline AGE OF HSEHOLO HEAO I & $\cdot$ & 1 & & 1 & & 1 & & 1 & & 1 & & 1 & & I & \\
\hline UNDER OS,.......... & $9 . \equiv 5$ & 1 & 4.38 & 1 & 2.45 & 1 & 1.04 & 1 & 1.71 & 1 & 2.41 & 1 & 2.54 & 1 & 5.53 \\
\hline 65 AND DVER ........ ! & $.10 . \pm 5$ & 1 & 6.75 & 1 & 3.24 & i & 2.72 & 1 & 3.30 & $\vdots$ & 4.23 & 1 & 4.52 & 1 & 5.01 \\
\hline RACE OF HSEHOLO HEADI & & 1 & & 1 & & 1 & & 1 & & 1 & & 1 & & 1 & \\
\hline WHITE,.........। & $9 . a b$ & 1 & 4.55 & i & 2.49 & 1 & 1.73 & 1 & 1.86 & 1 & 2.60 & 1 & 2.95 & 1 & 5.45 \\
\hline BLACK............. & 10.34 & 1 & 5.99 & 1 & 3.16 & 1 & 2.24 & 1 & 2.78 & 1 & .3 .44 & i & 2.87 & 1 & 5.82 \\
\hline OTHER.............. & 9.25 & 1 & 4.54 & 1 & 2.52 & 1 & 1.54 & 1 & 2.07 & 1 & 2.86 & 1 & 2.08 & 1 & 5.42 \\
\hline 1 & & 1 & & 1 & & 1 & & 1 & & 1 & & 1 & & 1 & \\
\hline SEX DF HSEHOLO HEAO II & & 1 & & 1 & & 1 & & 1 & & 1 & & 1 & & I. & \\
\hline MALE $\ldots \ldots \ldots \ldots \ldots \ldots$ & 9.58 & 1. & 4.28 & 1 & 2.40 & 1 & 1.60 & 1 & 1.70 & 1 & 2.11 & 1 & 2.52 & 1 & 5.52 \\
\hline FEMALE........... & 10.24 & 1 & 0.66 & 1 & .3 .28 & 1 & 2.03 & $!$ & 3.33 & 1 & 4.59 & 1 & 4.40 & 1 & 5.11 \\
\hline 1 & & 1 & & 1 & & 1 & & $!$ & & 1 & & 1 & & 1 & \\
\hline TENURE: & & 1 & & 1 & & 1 & & 1 & & 1 & & 1 & & 1 & \\
\hline AENTED............ & 9.87 & 1 & 5.02 & 1 & 2.60 & 1 & 1.84 & 1 & 2.12 & 1 & .3 .36 & 1 & 3.20 & 1 & 5.73 \\
\hline OWNED ............। & 9.19 & 1 & 4.43 & 1 & 2.48 & 1 & 1.73 & $\mathbf{I}$ & 1.79 & 1 & 2.28 & 1 & 2.134 & 1 & 5.29 \\
\hline OTHER ............. & 1.3 .04 & 1 & 6.28 & 1 & 3.74 & 1 & 1.98 & 1 & 3.23 & 1 & 3.26 & 1 & 2.69 & $!$ & 7.61 \\
\hline
\end{tabular}

SEE $S$ STICAL NOTES 
TABLE A.55

AVERAGE FUEL EXPENDITURE OF ELDERLY MOUSEHOLOS AS A PERCENT OF DISPOSABLE INCCME-I985 BY I978 ARC PROJECTION SERIES C

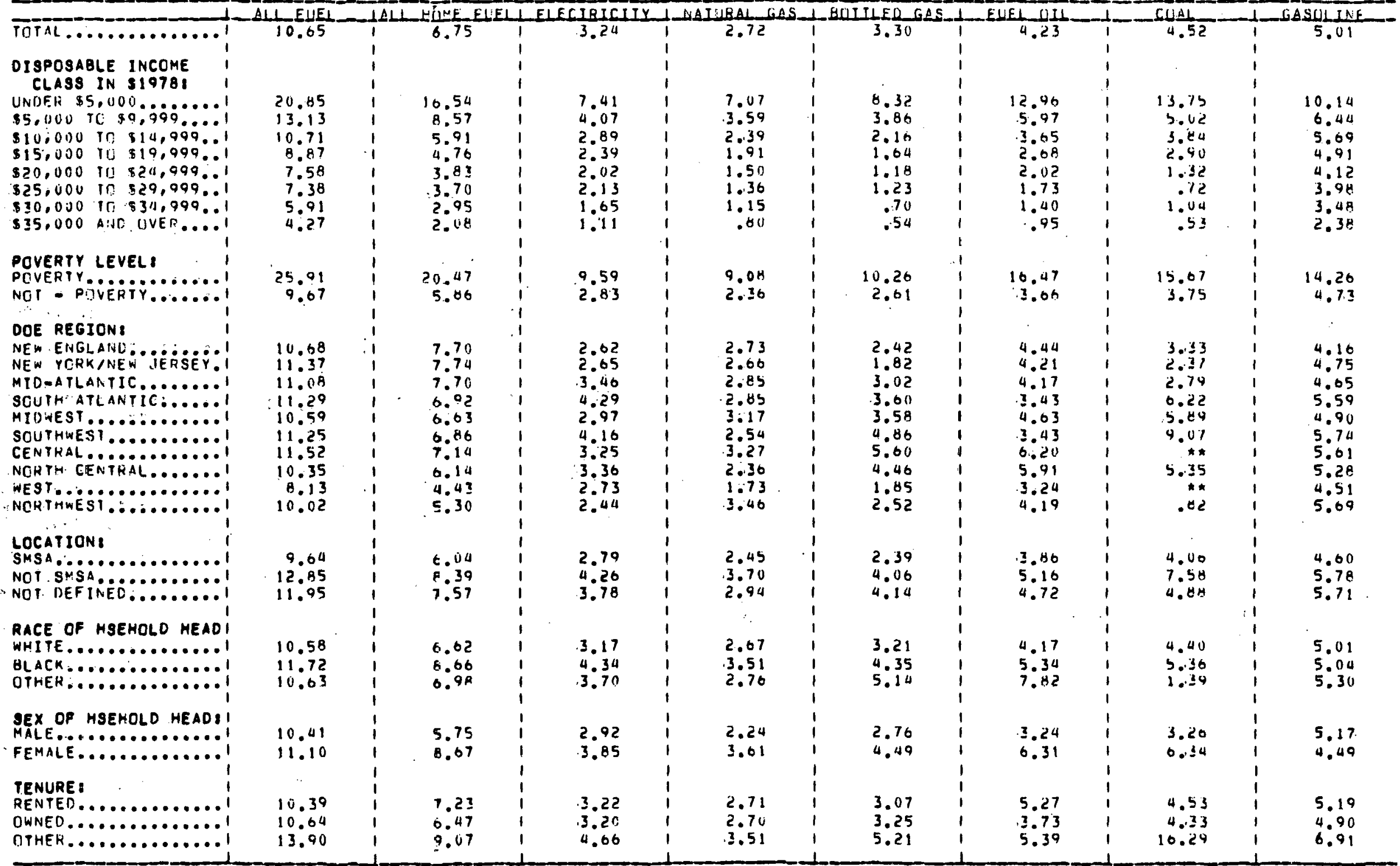

SEE STATISTICAL NOTES 
TABLE A. 56

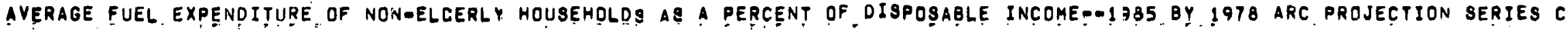

\begin{tabular}{|c|c|c|c|c|c|c|c|c|c|c|c|c|c|c|c|}
\hline $2=1$ & 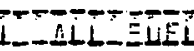 & 1 & SOSE & 1. & CIEIS & & ISAL_G & & LED_. & & iEL_CL & & 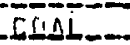 & & 15OLINE \\
\hline TUTAL............. & 19.55 & 1 & 4.38 & 1 & 2.45 & 1 & 1.64 & 1 & 1.71 & 1 & 2.41 & 1 & 2.59 & 1 & 5.53 \\
\hline 1 & 1 & 1 & & 1 & & 1 & & 1 & & 1 & & 1 & & 1 & \\
\hline DIOPOSABLE INCOME & 1 & 1 & & 1 & & 1 & & 1 & & 1 & & 1 & & 1 & \\
\hline CLASS IN $\$ 1978 !$ & I & 1 & & 1 & & 1 & & 1 & & 1 & & 1 & & 1 & \\
\hline UNDER $\$ 5.0100 \ldots \ldots \ldots 1$ & 35.64 & 1 & 16.45 & 1 & 10.00 & 1 & 1.29 & 1 & 9.34 & $i$ & 13.34 & 1 & j1.rid & 1 & 27.03 \\
\hline$\$ 5,000$ TC $\$ 9,999 \ldots \ldots 1$ & $16.7^{\mathrm{n}}$ & 1 & 8.43 & 1 & 4.52 & 1 & 3.15 & 1 & 3.72 & 1 & 5.63 & 1 & 4.56 & 1 & 11.25 \\
\hline$\$ 10,000$ T. $\$ 14.999 .1$ & 12,33 & 1 & 5.84 & $i$ & 3.18 & $i$ & 2.21 & 1 & 2.23 & $i$ & 3.54 & $i$ & $3.3 x$ & 1 & 7.35 \\
\hline$\$ 15,010$ ro $\$ 19,990 . .1$ & 10.69 & 1 & 4.63 & 1 & 2.66 & 1 & 1.08 & 1 & 1.59 & $!$ & 2.63 & 1 & 2.67 & 1 & 6.14 \\
\hline$\$ 20,000 \quad 70 \$ 24,999 \ldots 1$ & 8.37 & 1 & 3.95 & 1 & 2.25 & 1 & 1.47 & 1 & 1.23 & $i$ & 2.10 & 1 & 2.03 & 1 & 5.00 \\
\hline$\$ 25,0000$ Ti $\$ 29,009 \ldots 1$ & 9.07 & $!$ & 3.47 & 1 & 2.01 & 1 & $1.29=$ & 1 & 1.08 & 1 & 1.A2 & 1 & 1.4 .9 & 1 & H.64 \\
\hline$\$ 30,000$ T! $\$ 311,999 \ldots 1$ & 7.24 & 1 & 3.10 & 1 & 1.83 & 1 & 1.14 & 1 & .93 & 1 & $1.3 n$ & 4 & .97 & $!$ & 4.2 .3 \\
\hline$\$ 35,000$ AUL, UVER....! & $5.3 ?$ & 1 & 2.32 & 1 & $1.3 t$ & $\mathbf{i}$ & .97 & 1 & .59 & $!$ & 1.05 & 1 & 1.07 & 1 & 3.11 \\
\hline & 1 & 1 & & 1 & & 1 & & 1 & & 1 & & $!$ & & 1 & \\
\hline POVERTY LEVEL \& , 1 & 1 & 1 & & 1 & & 1 & & 1 & & 1 & & 1 & & 1 & \\
\hline PUVEFTY.............. & $31) .54$ & 1 & 16.69 & 1 & 9.10 & 1 & 0.44 & 1 & 7.97 & $!$ & 11.39 & 1 & 7.45 & 1 & 23.47 \\
\hline NOT - PIIVEHTY . ...... & 9.18 & 1 & 4.16 & 1 & 2.33 & 1 & 1.56 & 1 & 1.55 & $i$ & 2.29 & 1 & 2.43 & 1 & 5.33 \\
\hline ! & . & i & & 1 & & 1 & & $i$ & & 1 & & 1 & & i & \\
\hline DOE REGIONI & 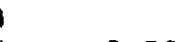 & 1 & & 1 & & 1 & & 1 & & 1 & & $!$ & & 1 & \\
\hline NEW EHGLANL. ........ & 9.79 & 1 & 5.210 & 1 & 2.20 & 1 & 2.01 & 1 & 1.22 & 1 & 2.44 & 1 & 1.49 & 1 & 4.95 \\
\hline NEW YORK/NE: JERSEY,I & 9.47 & 1. & 5.01 & 1 & 2.01 & 1 & 1.96 & 1 & 1.16 & 1 & 2.49 & ! & $2.01:$ & 1 & 0.94 \\
\hline MIDOATLANTIC,....... & 9.79 & 1 & 5.00 & 1 & ?. .57 & 1 & 1.74 & 1 & 1.37 & 1 & 2.46 & 4 & 1.93 & 1 & 5.37 \\
\hline SUUTH ATLANTIC...... & 10.54 & 1 & 4.62 & 1 & 3.19 & 1 & 1.72 & 1 & 1.97 & 1. & 2.IA & 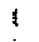 & 2.60 & 1 & 6.45 \\
\hline MIDWESI $\ldots \ldots \ldots \ldots \ldots$ & 9.13 & 1 & 4.15 & $\mathbf{I}$ & 2.21 & 1 & 1.77 & 1 & 1.87 & 1 & 2.39 & 1 & 3.95 & 1 & 5.26 \\
\hline SUUTHWEST . . . . . . . . . & 10.23 & 1 & 4.53 & 1 & 3.13 & $!$ & 1.42 & 1 & 2.21 & 1 & 1.34 & 1 & 2.33 & 1 & 0.12 \\
\hline CENTRAL $\ldots \ldots \ldots \ldots$ & 10.10 & $\mathbf{I}$ & 4.33 & 1 & 2.36 & 1 & 1.73 & 1 & 2.82 & 1 & 2.70 & 1 & 3.06 & 1 & 0.11 \\
\hline NURTH CENTFAL........ & 9.59 & 1 & $3.9 n$ & 1 & 2.39 & 1 & 1.38 & 1 & 2.37 & $\mathbf{I}$ & 3.04 & 1 & 2.22 & 1 & 5.71 \\
\hline WEST $\ldots \ldots \ldots \ldots \ldots \ldots \ldots$. & 8.39 & 1 & 3.37 & 1 & $2.2 \kappa$ & 1 & 1.18 & 1 & 1.37 & 1 & 1.45 & 1 & 3.14 & 1 & 5.27 \\
\hline NURTHWEST . . . . . . . . . . & 8.56 & 1 & 3.02 & 1 & 1.57 & 1 & दे. 10 & 1. & 1.09 & 1 & 2.20 & $\mathbf{I}$ & 1.39 & 1 & $5.6:$ \\
\hline ด & 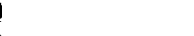 & 1 & & 1 & & 1 & & 1 & & 1 & & 1 & & 1 & \\
\hline LOCATIDN: & 1 & 1 & & 1 & & 1 & & 1 & & 1 & & 1 & & 1 & \\
\hline SMgA. $\ldots \ldots \ldots \ldots \ldots$ & 0.42 & 1 & 4.10 & 1 & 2.23 & 1 & 1.57 & 1 & 1.03 & 1 & 2.34 & 1 & 2.72 & 1 & 5.17 \\
\hline NUT SI:SA........... & 11.11 & 1 & 5.11 & 1 & 3.01 & 1 & 1.79 & 1 & 1.99 & I & 2.51 & I & 2.13 & 1 & 0.37 \\
\hline NUT DEF I $[E D \ldots \ldots \ldots \ldots$ I & 10.66 & $!$ & 4.60 & 1 & 2.51 & 1. & 1.72 & 1 & 1.98 & $!$ & $2.3 n$ & 1 & 3.15 & $i$ & 2.21 \\
\hline & & 1. & & $\mathbf{I}$ & & 1 & & 1 & & 1 & & 1 & & 1 & \\
\hline RACE OF HSEHOLD HEEADI & & 1 & & 1 & & 1 & & 1 & & 1 & & 1 & & 1 & \\
\hline WHITE $\ldots \ldots \ldots \ldots \ldots \ldots \ldots$ L & 9.53 & 1 & 4.26 & 1 & 2.40 & 1 & 1.60 & 1 & 1.64 & 1 & 2.33 & 1 & 2.6 .4 & 1 & 5.50 \\
\hline BLACK $: \ldots \ldots \ldots \ldots \ldots$ & 9.96 & $!$ & 5.72 & 1 & 3.05 & 1 & 2.12 & 1 & 2.56 & I. & 3.25 & 1 & 2.50 & 1 & S.dy \\
\hline DTHER............... & 9.14 & 1 & 4.35 & $!$ & 2.42 & 1 & 1.50 & 1 & 1.70 & 1 & $2.6^{\circ}$ & 1 & 2.09 & 1 & 5.43 \\
\hline & 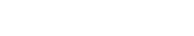 & 1 & & 1 & & 1 & & 1 & & 1 & & 1 & & 1 & \\
\hline SEX OF HSEHOLD HESAOII & & $!$ & & $\mathbf{I}$ & & 1 & & 1 & & 1 & & 1 & & 1 & \\
\hline MALE............. & 9.55 & 1 & 4.13 & 1 & 2.35 & 1 & 1.53 & 1 & 1.58 & 1 & 2.19 & 1 & 2.42 & 1 & 5.50 \\
\hline FEMALE $\ldots \ldots \ldots \ldots \ldots$ & 9.91 & 1 & 5.96 & $\mathbf{i}$ & 3.09 & 1 & 2.30 & 1 & 2.82 & 1 & 3.8 .4 & 1 & 3.50 & 1 & 5.27 \\
\hline 1 & I & $!$ & & $\mathbf{I}$ & & $!$ & & 1 & & 1 & & 1 & & 1 & \\
\hline TENURE I & 1 & 1 & & $\mathbf{I}$ & & 1 & & ! & & 1 & & 1 & & 1 & \\
\hline RENTED .............। & 9.51 & 1 & 4.77 & 1 & 2.53 & 1 & 1.74 & 1 & 2.01 & 1 & 3.08 & 1 & $2.9 M$ & 1 & 5.17 \\
\hline OWNED :............। & 0.21 & 1 & 4.12 & 1 & 2.37 & 1 & 1.58 & 1 & 1.54 & 1 & 2.03 & 1 & 1.94 & 1 & 5.35 \\
\hline DTHE & 12.59 & $!$ & 5.79 & 1 & 3.58 & 1 & 1.73 & 1 & 2.87 & 1 & 2.85 & $!$ & $2 . ! n$ & 1 & 7.70 \\
\hline
\end{tabular}

SEE STATISTICAL NOTES 
TABLE 57

PERCENTAGES OF ALL HOUSEHOLDS BY SPECIFIC CHARACTERISTICS BY TYPE OF FUEL USED-1985 BY 1978 ARC PROJECTION SERIES C

\begin{tabular}{|c|c|c|c|c|c|c|c|c|c|c|}
\hline-1 & ALL EVEL & LOLL HOME FUELL & ELECTRICIIY 1 & NAIUSAL GAS I & LBOIILEY GAS I & FUEL & CIL & COAL & 1 & GASULINE \\
\hline TDTAL_..............। & 100.001 & $1 \quad 100.001$ & 100.001 & 73.811 & 9.471 & & 22.771 & & 0.381 & 82.47 \\
\hline 1 & 1 & 1 & 1 & 1 & 1 & & 1 & & 1 & \\
\hline DI SPOSABLE INCOME & 1 & i & 1 & 1 & I & & I & 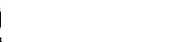 & i & \\
\hline CLASS IN $\$ 1978:$ & 1 & 1. & 1 & 1 & 1 & & 1 & & 1 & \\
\hline UNOER $\$ 5,000 \ldots \ldots \ldots 1$ & 100.001 & $100.00 !$ & 100.001 & 70.891 & 12.051 & & 21.181 & & .431 & 49.79 \\
\hline$\$ 5,000$ ru $\$ 9,999 \ldots \ldots 1$ & 100.001 & 100.001 & 100.001 & 72.311 & 10.531 & & 22.381 & & $.45 i$ & 72.18 \\
\hline$\$ 10,000$ T0 $\$ 14,994 \ldots 1$ & 100.001 & $10 n . n n i$ & 100.001 & 73.671 & 10.241 & & 22.681 & & .471 & 87.45 \\
\hline$\$ 15,000$ TO $\$ 19,994 \ldots 1$ & 100.001 & 100.001 & 100.001 & 74.051 & 0.191 & & 23.971 & & .481 & 93.66 \\
\hline$\$ 20,000 \quad 10 \$ 24,999 \ldots 1$ & 100.001 & 100.001 & 100.001 & 75.411 & 7.661 & & 23.731 & & .221 & 97.01 \\
\hline$\$ 25,000$ TO $\$ 29,999 \ldots 1$ & 100.001 & 100.001 & 100.001 & 70.021 & 7.391 & & 21.641 & & .421 & 97.56 \\
\hline$\$ 30,000$ TO $\$ 34,444 \ldots 1$ & 100.001 & 100.001 & 100.001 & 76.021 & 7.161 & & 21.381 & & .101 & 97.10 \\
\hline$\$ 35,000$ AND UVER $\ldots .$. & 100.001 & $100.00 !$ & $100.00 !$ & 77.011 & $6.03 !$ & & $25.57 !$ & & .101 & 90.27 \\
\hline POVERTY LEVEL: & i & 1 & 1 & 1 & i & & $i$ & 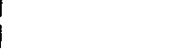 & 1 & \\
\hline POVERTY.......... & 100.001 & 100.001 & 100.001 & 69.821 & 12.521 & & 18.931 & & .461 & 50.06 \\
\hline NUT - PUVERTY $\ldots \ldots \ldots l$ & 100.001 & $100.00 !$ & 100.001 & $74.34 !$ & 9.061 & - & 2.3 .291 & & .371 & 86.81 \\
\hline$\therefore$ & 1 & 1 & 1 & 1 & 1 & & 1 & 1 & 1 & \\
\hline DOE REGION: & i & 1 & 1 & 1 & 1 & & 1 & 1 & 1 & \\
\hline NEW ENGLAND $\ldots \ldots \ldots \ldots$ I & 100.001 & 100.001 & 09.991 & 58.501 & 12.471 & & 72.631 & & .061 & 78.66 \\
\hline NEW YORK/NEW JERSEY.I & 1010.001 & $100.00 !$ & 100.001 & 79.331 & 8.711 & & 59.621 & & .351 & 76.21 \\
\hline 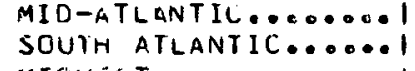 & $\begin{array}{l}100.001 \\
100.001\end{array}$ & $\begin{array}{l}100.001 \\
100.001\end{array}$ & $\begin{array}{l}100.001 \\
100.001\end{array}$ & $\begin{array}{l}71.181 \\
48.271\end{array}$ & $\begin{array}{r}8.551 \\
13.831\end{array}$ & & $\begin{array}{l}40.861 \\
18.591\end{array}$ & & $\begin{array}{l}.951 \\
.161\end{array}$ & $\begin{array}{l}81 \cdot 37 \\
81.39\end{array}$ \\
\hline & 100.001 & 100.001 & & 84.061 & $\begin{array}{r}7.801 \\
10.001\end{array}$ & & $\begin{array}{r}13.101 \\
1.091\end{array}$ & & .411 & $\begin{array}{l}84.68 \\
82.06\end{array}$ \\
\hline 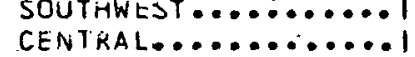 & $\begin{array}{l}100.001 \\
100.001\end{array}$ & $\begin{array}{l}100 . n n 1 \\
100.001\end{array}$ & $\begin{array}{r}100.001 \\
99.991\end{array}$ & 83.671 & 13.571 & & 6.831 & & $.0<1$ & $\begin{array}{l}82.00 \\
83.36\end{array}$ \\
\hline NOKTH CENTKAL........ & 100.001 & 100.001 & 100.001 & 80.801 & 4.471 & & .7 .221 & & .401 & 86.42 \\
\hline WEST $\ldots \ldots \ldots \ldots \ldots \ldots$ i & 100.001 & 100.001 & 100.001 & 88.931 & $4.94 !$ & & .701 & & .011 & 86.27 \\
\hline NOR THWEST . .......... & 100.001 & $100.00 !$ & $100.00 !$ & $43.26 !$ & $7.84 !$ & & $22 \cdot 781$ & & .031 & 87.54 \\
\hline & & 1 & 1 & ! & 1 & & I & 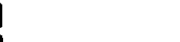 & 1 & \\
\hline LOCATION: & & 1 & 1 & 1 & 1 & & 1 & I & 1 & \\
\hline SMSA............ & 100.001 & $100 \cdot 001$ & 100.001 & 80.061 & 6.211 & & 22.071 & & .421 & 82.03 \\
\hline NOT SMSA............ & 100.001 & 100.001 & 100.001 & 57.981 & $15.85 !$ & & 24.851 & I & .431 & 82.63 \\
\hline NUT DEFINEU........ & 100.001 & $100.00 !$ & 100.001 & 66.581 & $13.71 !$ & & $22.87 !$ & & $.19 !$ & 83.62 \\
\hline ar & & I & 1 & 1 & I & & 1 & $\mathbf{I}$ & 1 & \\
\hline AGE OF HSEMOLD HEAD: I & & 1 & 1 & $\ldots 1$ & 1 & & 1 & 1 & 1 & \\
\hline UNDEK O5........... I & 100.001 & 100.001 & 100.001 & $74: 14 !$ & 9.1 .51 & & 22.141 & & .371 & 87.89 \\
\hline 65 AND OVER. $\ldots \ldots \ldots$ ! & 100.001 & $10 n \cdot 0 n !$ & 100.001 & $72.57 !$ & $10.65 !$ & & $25.14 !$ & & $.44 !$ & 62.35 \\
\hline RACE OF HSEHOLD HEADI & & ! & 1 & & 1 & 1 & 1 & 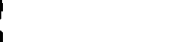 & .1 & \\
\hline WHITE............ & & 100.001 & 2000 & 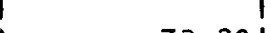 & 1 & & -1 & ! & -1 & \\
\hline 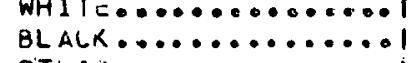 & $\begin{array}{l}100.001 \\
100.001\end{array}$ & $\begin{array}{l}100.001 \\
100.001\end{array}$ & $\begin{array}{r}100.001 \\
99.091\end{array}$ & $\begin{array}{l}73.201 \\
78.281\end{array}$ & $\begin{array}{l}9.491 \\
9.331\end{array}$ & & $\begin{array}{l}23.081 \\
20.821\end{array}$ & & $\begin{array}{l}.341 \\
.711\end{array}$ & $\begin{array}{l}85.90 \\
55.41\end{array}$ \\
\hline OTHER ............ & & $100.0 n i$ & 100.001 & 79.261 & 8.621 & & 16.581 & & 1.041 & 73.94 \\
\hline & $i$ & 1 & I & 1 & 1 & & 1 & 1 & 1 & \\
\hline SEX OF HSEHOLD HEAD: I & & 1 & 1 & ! & 1 & & & & 1 & \\
\hline MALE $\ldots \ldots \ldots \ldots \ldots \ldots \ldots \mid$ & 100.001 & 100.001 & 100.001 & 72.461 & 9.921 & & 23.041 & & .361 & 92.19 \\
\hline FEMALE.......... & 100.001 & 100.001 & 100.001 & 77.281 & 8.311 & & 22.081 & & .431 & 57.37 \\
\hline & 1 & 1 & 1 & 1 & I & & 1 & 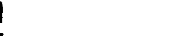 & 1 & \\
\hline TENURE : & 1 & 1 & 1 & 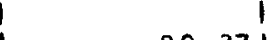 & -1 & & 1 & & 1 & \\
\hline RENTEO............ & 100.001 & 100.001 & 100.001 & $80.37 !$ & 6.531 & & 22.451 & & .591 & 73.53 \\
\hline OWNEO............! & 100.001 & 100.001 & 100.001 & 70.081 & 11.061 & & $23.00 !$ & & .241 & $\begin{array}{l}89.06 \\
77.04\end{array}$ \\
\hline UTHER............. & 100.001 & $100.00 !$ & 100.001 & 56.841 & $18.57 !$ & & 22.711 & & .391 & 77.04 \\
\hline
\end{tabular}

SEE STATISTICAL NOTES 
PERCENTAGES OF ELDERLY HOUSEHOLOS BY SPECIFIC CHARACTERISTICS BY TYPE OF FUEL USED-AI985 3Y I978 ARC PROJECTION :8ERIE8 C

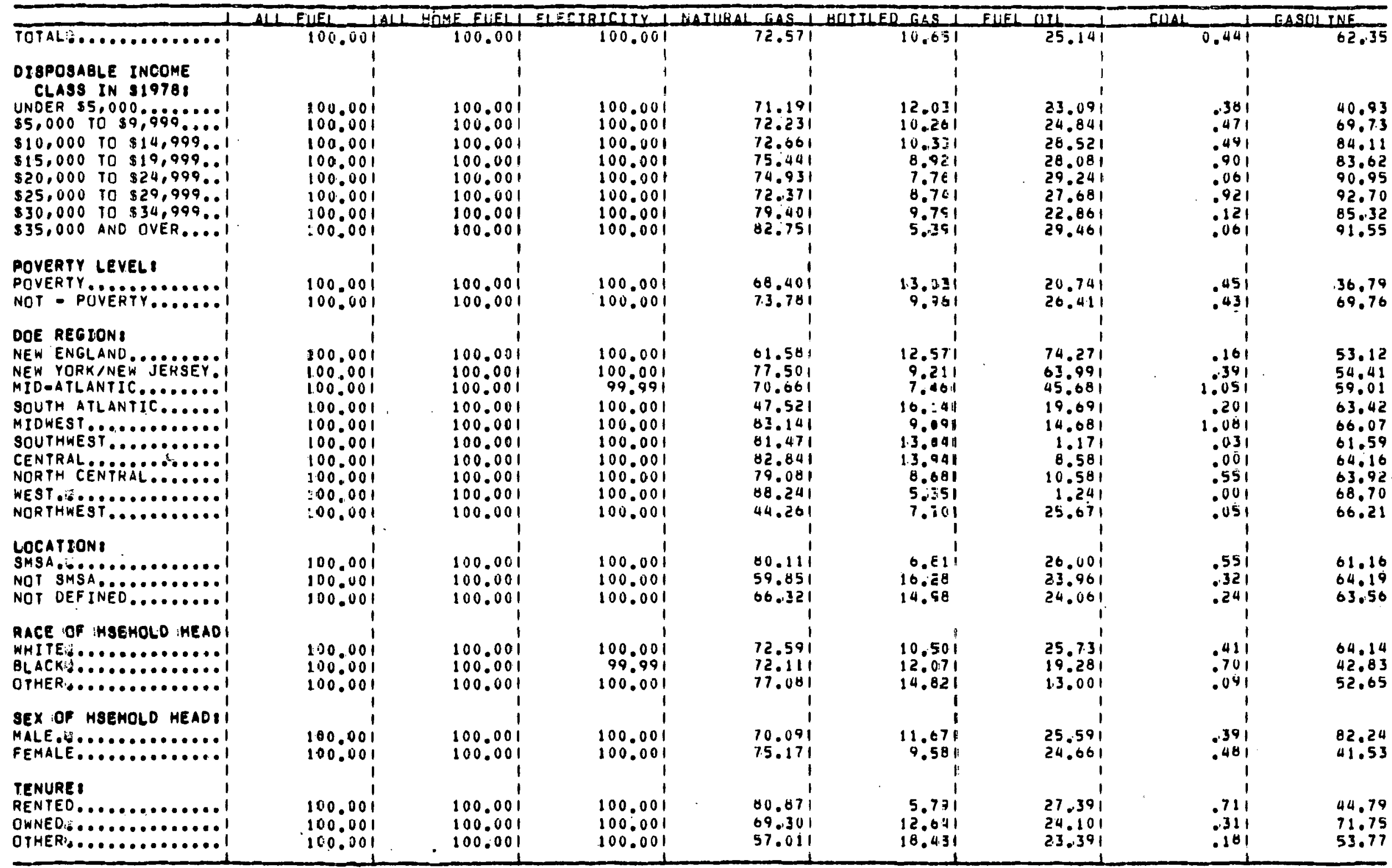


TABLE A. 59

PERCENTAGES OF NON-ELOERLY HOUSEHOLOS BY SPECIFIC CHARACTERISTICS BY TYPE OF FUEL USED:-I985 BY IOTB ARC PROJECTION SERIES C

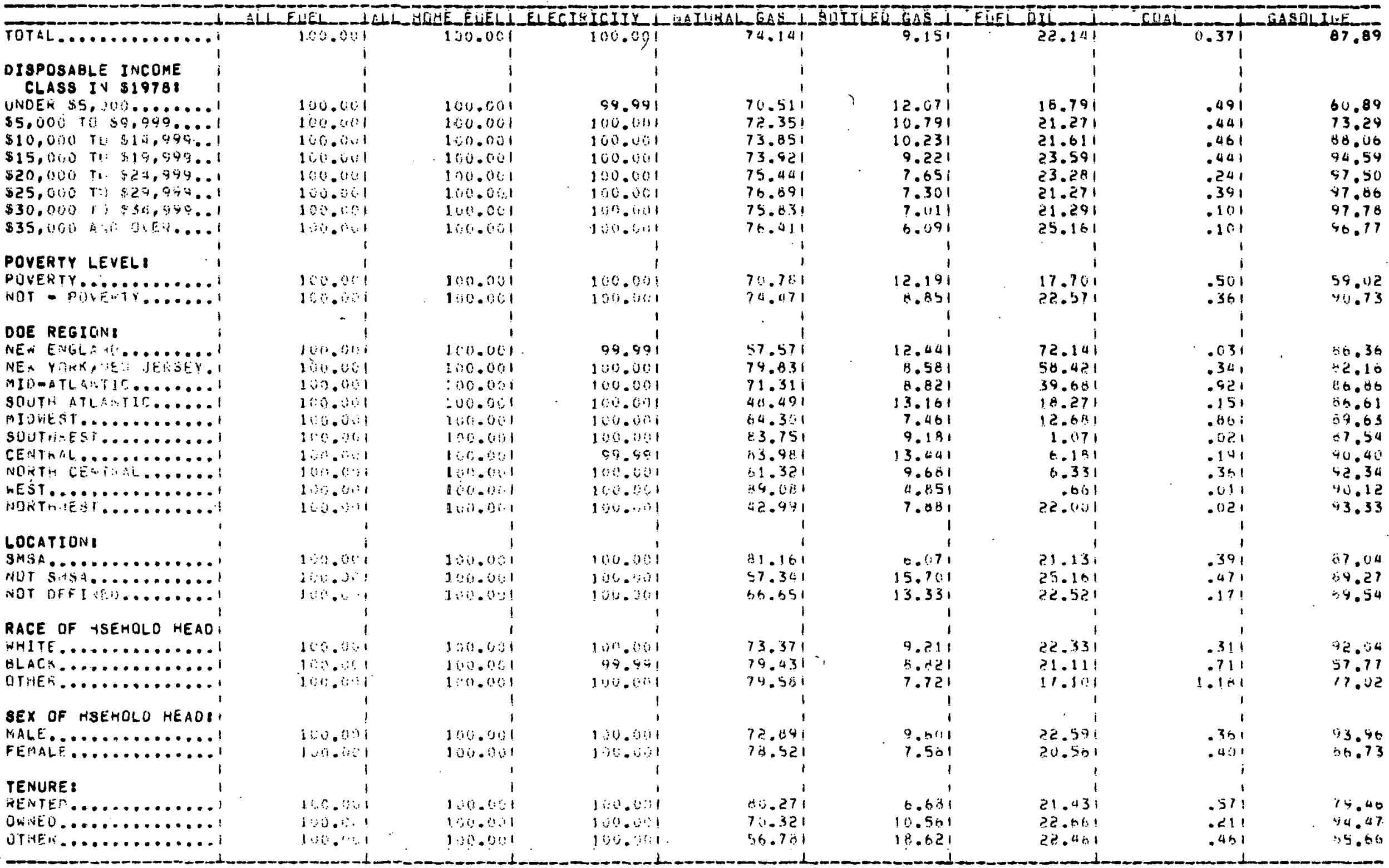

SEE STATISTICAL NOTES 
PERCENTAGES OF ALL HOUSEHOLOS BY SPECIFIC FUELS USEO BY CHARACTERISTIC - 1985 BY 1978 ARC PROJECTION SERIES C

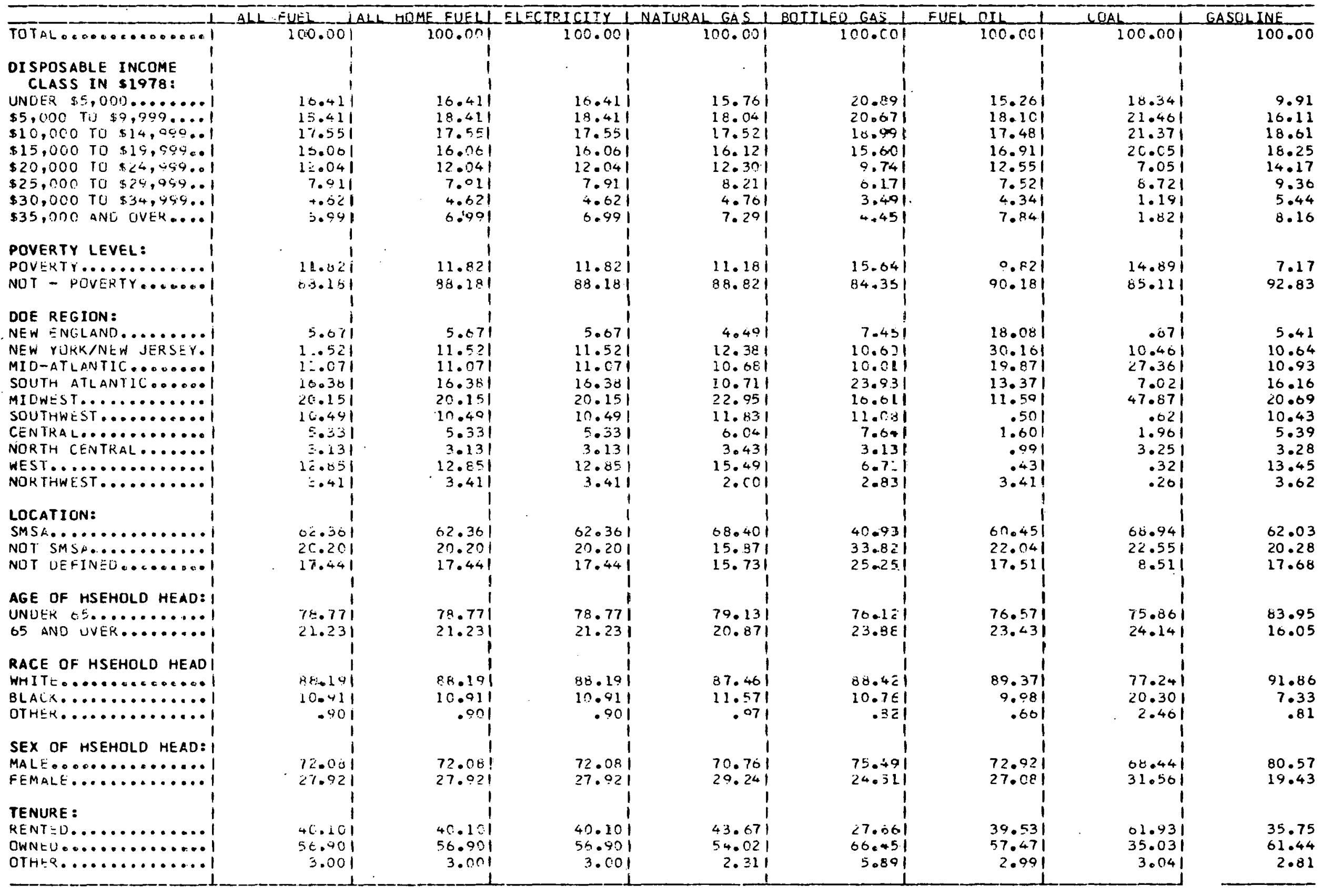


PERCENTAGES OF ELDERLY MOUSEHOLDS BY SPEÇIFIC FUELS USEO BY CHARACTERISTIC-OI985 BY IOT. ARC PROJECTION .8ERIES C

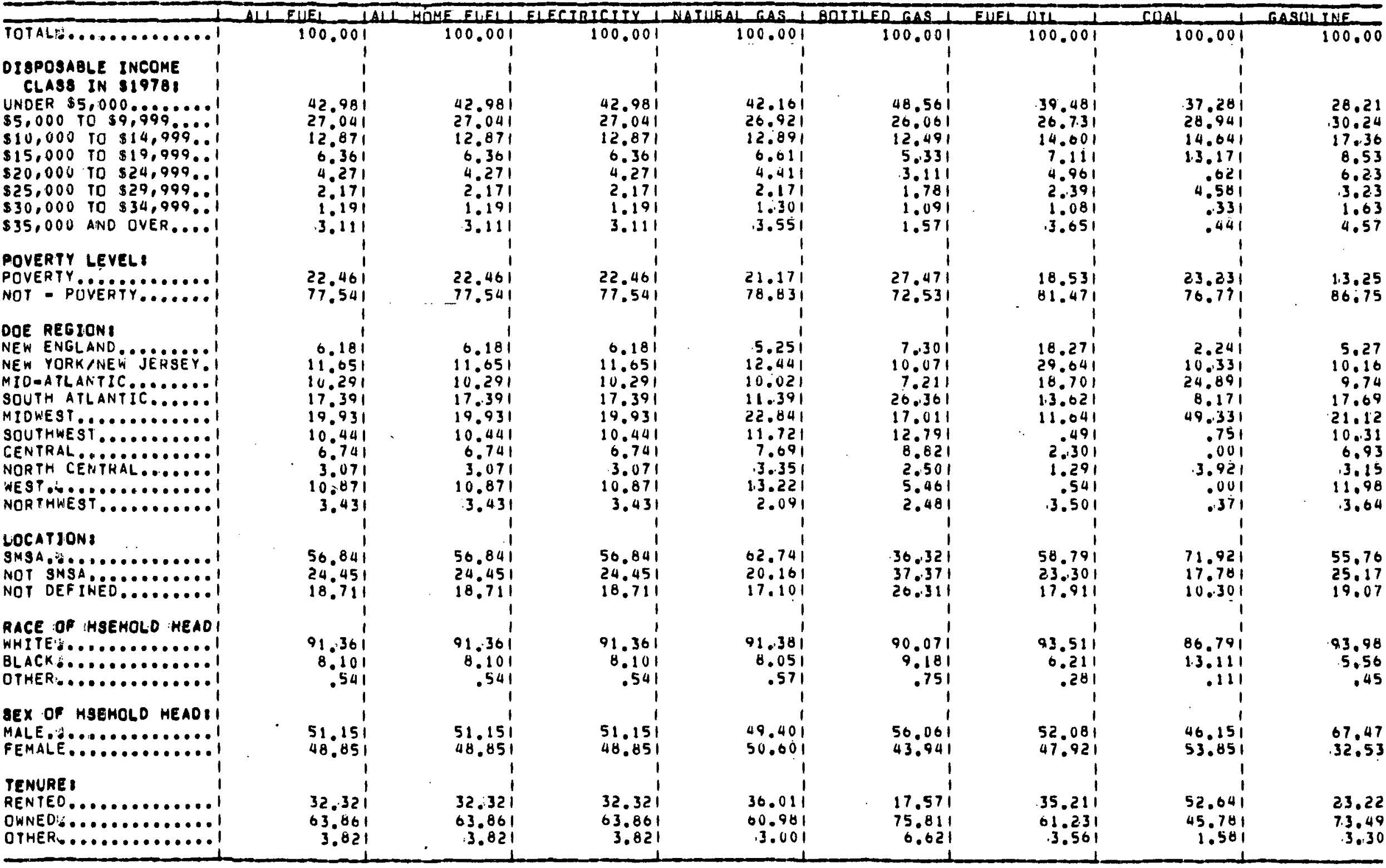

SEE STATISTICAL NOTES 
TABLE A. 62

PERCENTAGES OF NON-ELDERLY HOUSETOLDE BY SPECIFIC FUELS USED BY CHARACTERISTIC -1985 BY $13 T$ IO ARC PROJECTION SERIES C

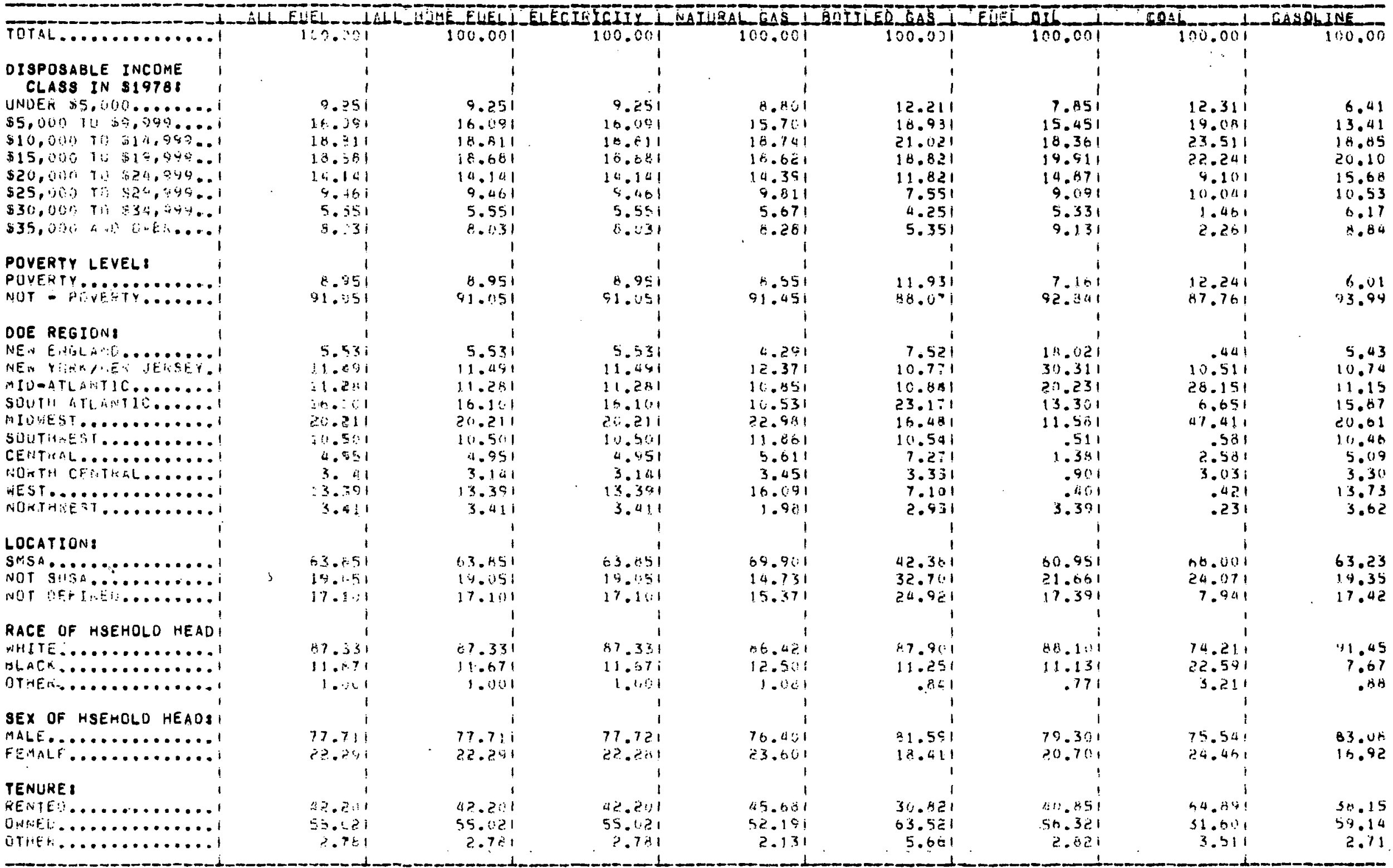

SEE ST. - TICAL NOTES 
Table A.63 Department of Energy Regions by State and Energy Prices by Fuel Type --1975 and 1985 (1978 Dollars)

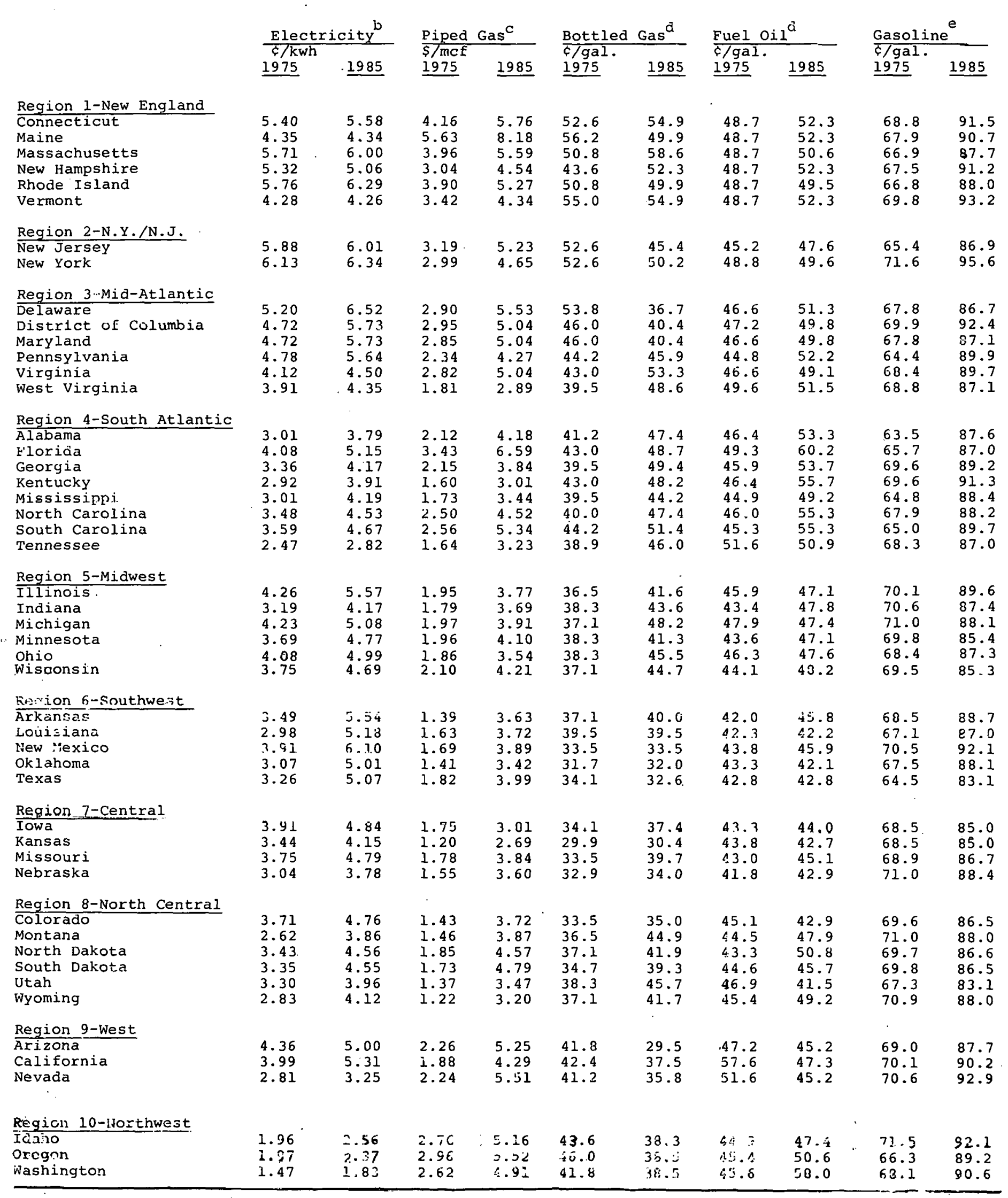

Scc footnotes on following page

See Statistical Notes 
a

All fuel prices for 1985 were obtained from Midterm Projections Series $C$ for the Annual Report to Congress 1978. Coal prices are omitted since there is no systematic collection of residential price data. MATH/CHRDS uses a coal price index for estimation.

b

Edison Electric Institute, Statistical Yearbook for 1975, New York, Edison Electric Institute, 1976, Tables 22S and $36 \mathrm{~S}$.

$c$

American Gas Association, 1976 Gas Facts, Arlington, Va., American Gas Association, 1976, Tables 65 and 80.

d

U.S. Department of Agriculture, Crop Reporting Board, Statistical Reporting Service, Argricultural Prices Annual Summary $1975, \operatorname{Pr} 1-3$ (76), Washington, D.C., USDA, June 1976, p.69

e

Platt's Oil Price Handbook and Oilmanac 1975, New York, N.Y., Mc Graw-Hill, Inc, 1976, p.105. 


\section{APPENDIX B}

\section{Statistical Notes}

1. Tabulated data include households with positive income, positive energy expenditure, and that reside in the lower continental United States. Persons in group quarters and residents of Alaska, Hawaii, and Puerto Rico are excluded from the tables.

2. Expenditures for each fuel type are only for households that use that particular fuel. The estimates in the tables cannot be added across all fuels to calculate total expenditures because not all households use all fuels.

3. The gross national product implicit price deflator is used for conversion to 1978 dollars. Historical deflators are used for 1975 (1.2718) and 1978 (1.5204 as of 4/79). The 1985 deflator is 2.2242 from Data Resources, Inc. 1985 TRENDLONG 1995 projection. For conversion to 1975 current dollars, multiply 1975 Table dollars, by 0.8365 . For conversion to 1985 current dollars, multiply 1985 Table dollars by 1.4629 .

4. Disposable income is defined as the sum of earnings, property income, private pensions and transfers, and government transfers (including value of food stamps), less federal income and payroll taxes. For the calculation of average fuel expenditure as a percentage of disposable income, the sum of expenditures for all households in each table cell is divided by the sum of the households' incomes.

5. Poverty status in 1974 is defined in terms of money income in 1978 dollars for families and individuals rather than households. A poverty index is used based on an "economy" food plan designated by the Department of Agriculture for "emergency or temporary use when funds are low". A family is classified as poor if 1 ts total money income is less than approximately three times the cost of the "economy" food plan. See U.S. Bureau of the Census, Public Use Samples of Basic Records from the 1970 Census: Description and Technical Documentation, Washinton, D.C., 1972. p.122.

6. Confidentiality requirements of the Bureau of the Census preclude reporting SMSA location in Delaware, Nevada, Rhode Island, Utah, Vermont, and Wyoming. For these States, households' SMSA locations are classified "Not Defined". 
7. "Other" Race of Household Head includes Indian, Japanese, Chinese, and any other race except White or Black.

8. Estimates are derived from MATH/CHRDS simulations for 1975 and 1985 prepared for the Energy Information Administration by Mathematica Policy Research, Inc. Data files are:

1975--C N6212. PR J. TPL . A 75N 81. AT 3BFMFL

1985--CN6212. PR J. PSC 369C 3.A85N 49.A 3ELT 5R 


\section{GPO SINGLE ISSUE AND ANNUAL ORDER FORM}

(For use in ordering EIA Publications only - Read Ordering Information Section before cornoleting form.) SEND ORDER FORM TO: Superintendent of Documents, U.S. Government Printing Office, Washington, D.C., 20402

\begin{abstract}
Enclosed is $\$$
$\square$ Check
\end{abstract}

$\square$ Money order, or charge to my Deposit Account No.

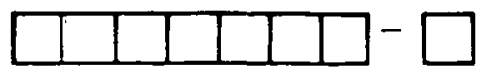

Order No.

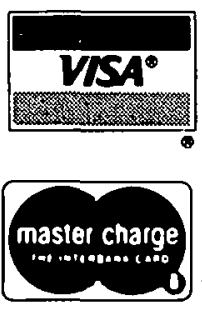

NAME AND ADDRESS

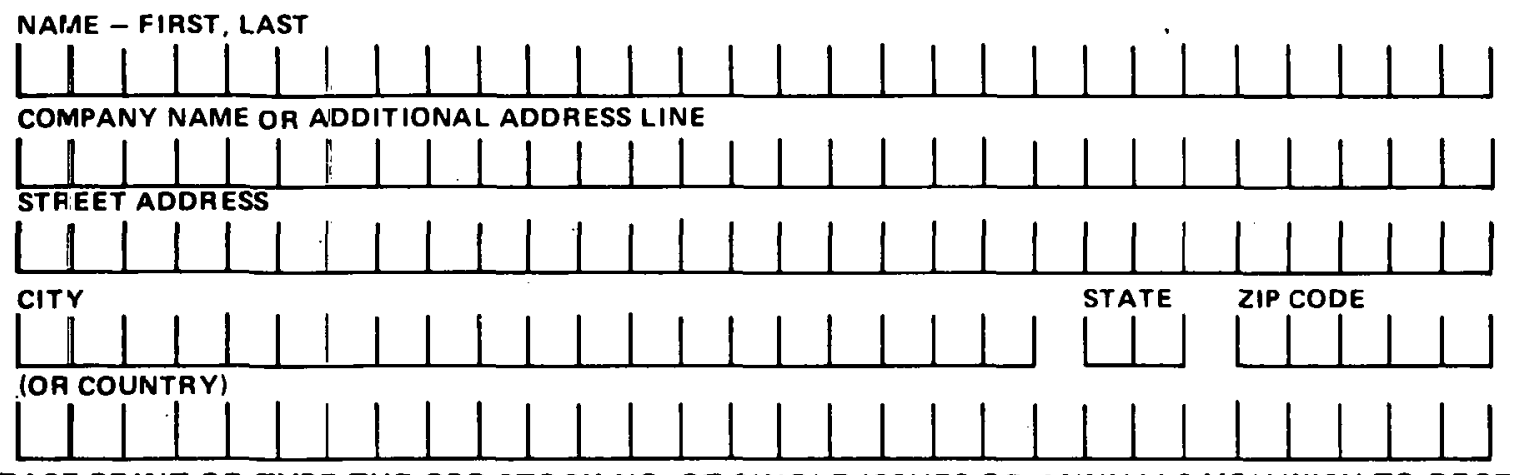

PLEASE PRINT OR TYPE THE GPO STOCK NO. OF SINGLE ISSUES OR ANNUALS YOU WISH TO RECEIVE

Total charges $\$$
Credit Card Orders Only

Fill in the boxes below

Credit

Card No.

Expiration Date Month/Year

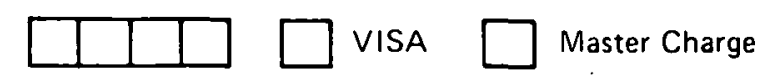


U.S. Department of Energy

Energy Information Administration

Office of Energy Information Services

1726 M St. N.W.

Washington, D.C. 20461

OFFICIAL BUSINESS

PENALTY FOR PRIVATE USE, $\$ 300$
US DEPT OF ENERGY PERMIT NO. G 20

FIRST CLASS MAIL 